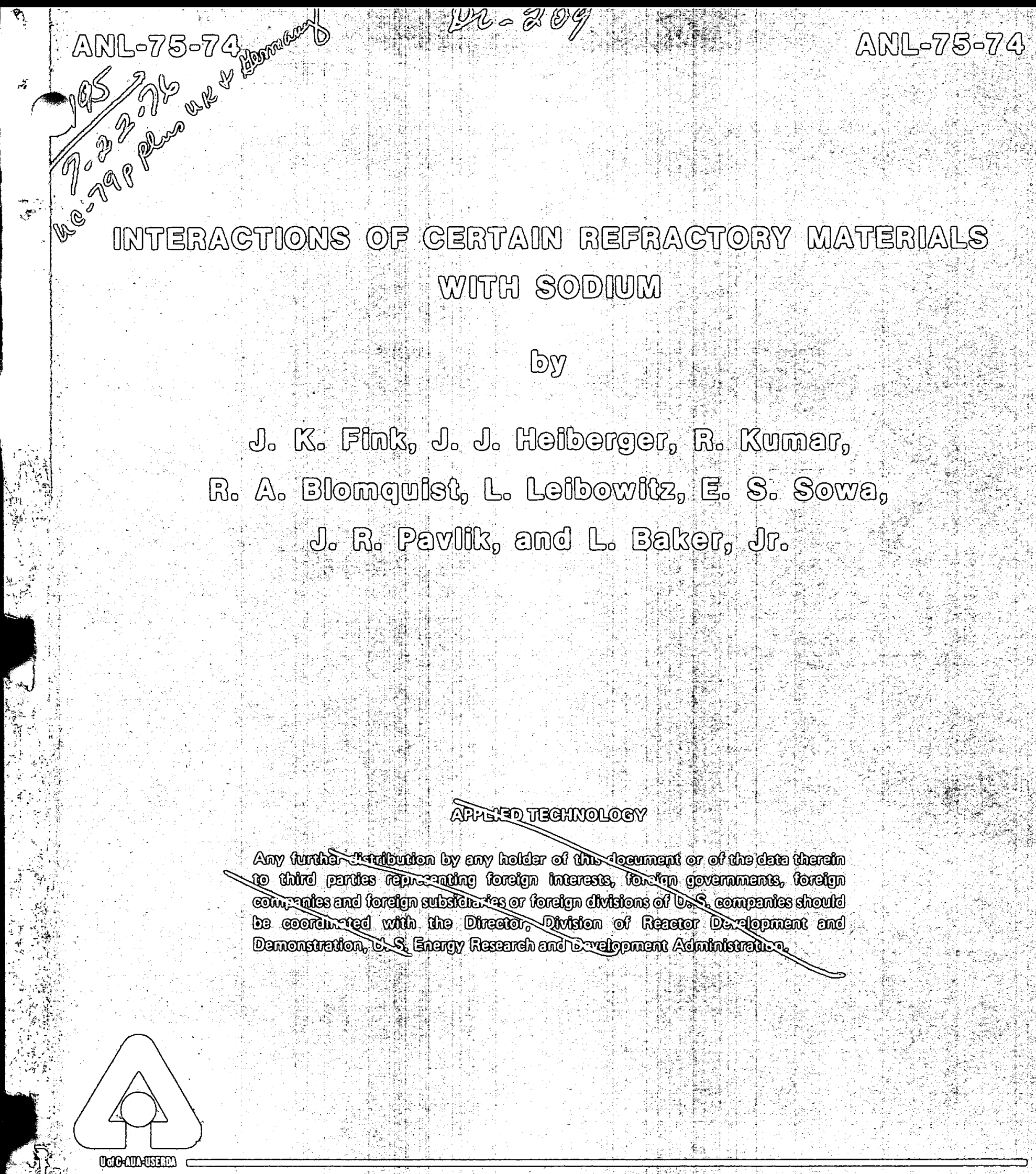




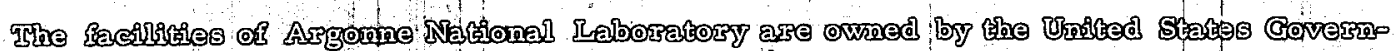

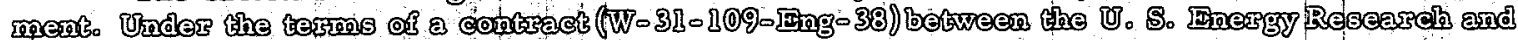
Develorment Adn

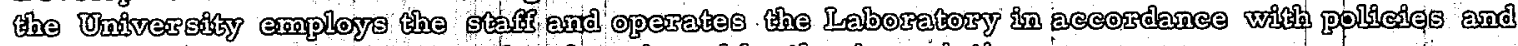

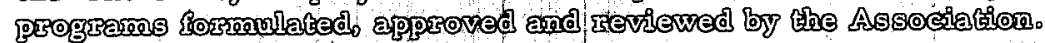

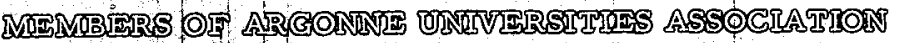

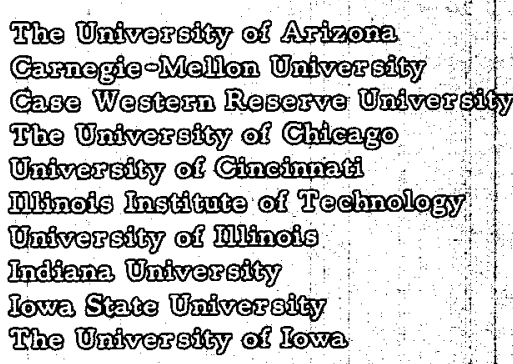

Ranisas Stare Tonfoereisy Thhe Trofoersity of Ransas Loyola Dontuorsisy

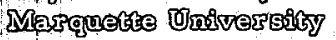

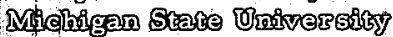

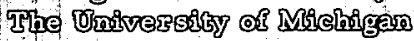
एonthorstivy of Whesora Un Nomblesters Trativersisy. Thatuersitsy of Nớre Dare
The Ohio Stare Thiversity Ohio Trwiversisty

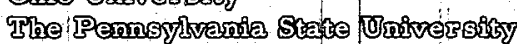
Purbe Trationsisy

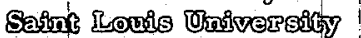

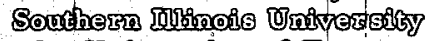

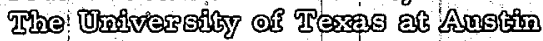

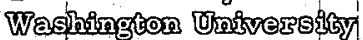
Waype Strat Trativersish पुर

Thints report was prepared as an acerrat of work sponsored

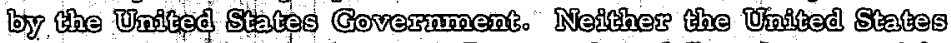

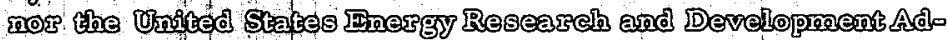
ख

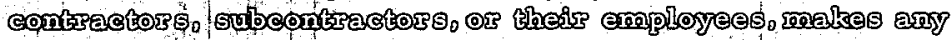

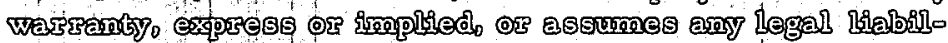

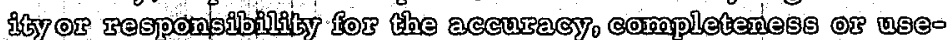

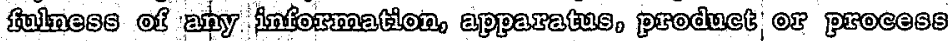

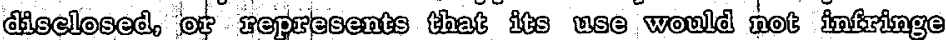

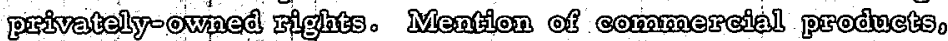

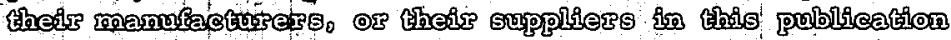

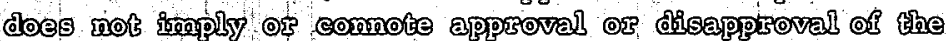

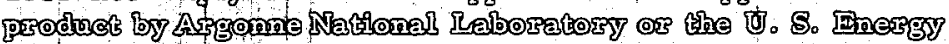

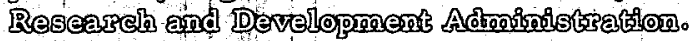
$1+$ to

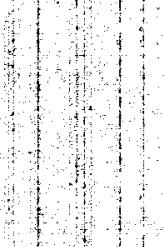

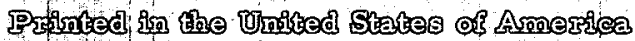
Avainlable trom

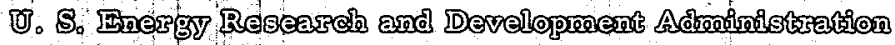

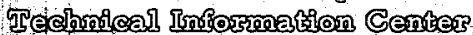
1. P. O. Bor 62 Qak Rifige

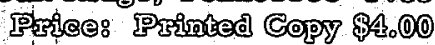


ANL $-75-74$

\author{
ARGONNE NATIONAL LABORATORY \\ 9700 South Cass Avenue \\ Argonne, Illinois 60439
}

\title{
INTERACTIONS OF CERTAIN REFRACTORY MATERIALS \\ WITH SODIUM
}

by

J. K. Fink, J. J. Heiberger, R. Kumar,

R. A. Blomquist, and L. Leibowitz

Chemical Engineering Division

and

This report was preporice

sponsored by the Prepared as an account of work
the United Rexearch and Diates nor the Unitornment. Neither thet employess, warrantractors, or the any of their not any of lisbility, express or impliemployces, maketors,

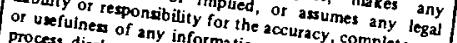
process disclosed, or represtion, apparatus, prieteness Wre privately omed rights. that its use would or

E. S. Sowa, J. R. Pavlik, and L. Baker, Jr.

Reactor Analysis and Safety Division

May 1976

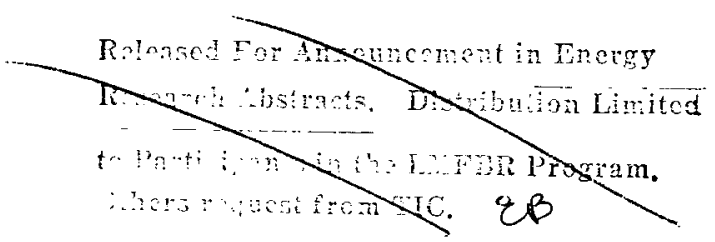




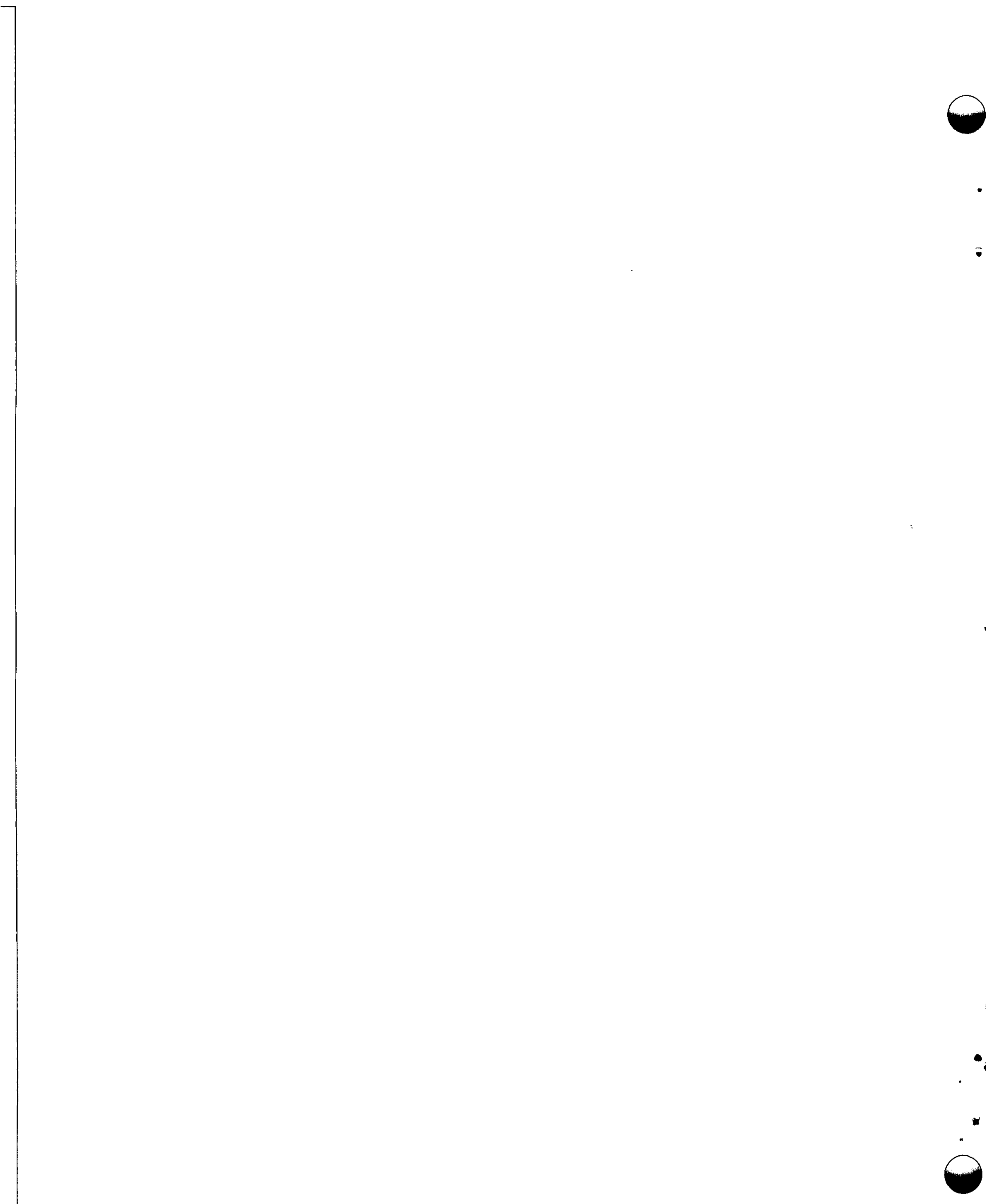


ABSTRACT. . . . . . . . . . . . . . . . . . . . . . . . 1

I. INTRODUCTION. . . . . . . . . . . . . . . . . . . . . 1

II. DESCRIPTION OF APPARATUS AND EXPERIMENTAL PROCEDURE . . . . . . . 3

A. Exposure to Static Sodium at $850^{\circ} \mathrm{C}$. . . . . . . . . . . . . . 4

B. Exposure to Boiling Sodium. . . . . . . . . . . . . 4

III. DISCUSSION OF RESULTS . . . . . . . . . . . . . . . . . 7

A. Magnesia Samples . . . . . . . . . . . . . . 17

B. Alumina Samples... . . . . . . . . . . . . . 17

C. High Zirconia Materials . . . . . . . . . . . . . . 22

D. Mixed Ceramic Oxides. . . . . . . . . . . . . . . 29

E. Graphite. . . . . . . . . . . . . . . . . . 35

F. Control Materials ................. . 35

G. Miscellaneous . . . . . . . . . . . . . . . 35

IV. CONCLUSION. . . . . . . . . . . . . . . . . . . . . . 41

ACKNOWLEDGEMENTS. . . . . . . . . . . . . . . . . . . . . 42

REFERENCES. . . . . . . . . . . . . . . . . . . . . . . 43 


\section{LIST OF FIGURES}

No.

1. Diagram of Test Assembly used for Static Sodium Exposure Tests. . . 5

2. Diagram of Apparatus used for Boiling Sodium Exposure Tests . . . . 6

3. High Magnesia Material, Harklase, before and after Sodium Exposure. 18

4. High Magnesia Material, Oxibak H, before and after Sodium Exposure. 19

5. High Magnesia Material, HW Magnesite, before and after Sodium Exposure. . . . . . . . . . . . . . . . . . . 20

6. High Magnesia Materia1, MN 197, before and after Exposure to Boiling Sodium. . . . . . . . . . . . . . . . . . 21

7. High-fired Recrystallized Alumina Crucible before and after Exposure to Boiling Sodium. . . . . . . . . . . . . . . . 21

8. Alumina Brick Sample before and after Exposure to Boiling Sodium. . 23

9. High Alumina Material, A-414, before and after Exposure to Boiling Sodium. . . . . . . . . . . . . . . . . . . . . 23

10. High Alumina Materia1, AH 199B, before and after Exposure to Boiling Sodium. . . . . . . . . . . . . . . . 24

11. High Alumina Material, AN 199B, before and after Exposure to Boiling Sodium. . . . . . . . . . . . . . . . . 24

12. High Alumina Material, SR-504C, before and after Exposure to Boiling Sodium. . . . . . . . . . . . . . . . . . 25

13. High Alumina Material, HW Corundum, before and after Sodium Exposure.

14. High Alumina Material, Korundal XD, before and after Exposure to Static Sodium at $850^{\circ} \mathrm{C}$. . . . . . . . . . . . . 27

15. High Alumina Material with $10 \% \mathrm{Cr}_{2} \mathrm{O}_{3}$, HW Ruby, before and after Exposure to Static Sodium . . . . . . . . . . . . . . 27

16. Zirconia Brick Sample, $2 \mathrm{H} 192 \mathrm{~A}$, before and after Exposure to Boiling Sodium. . . . . . . . . . . . . . . . . 28

17. High-fired Zirconia Crucible Piece before and after Exposure to Boiling Sodiun. . . . . . . . . . . . . . . . . 28

18. High-fired Zirconia Crucible, Norton Mix Z-302, before and after

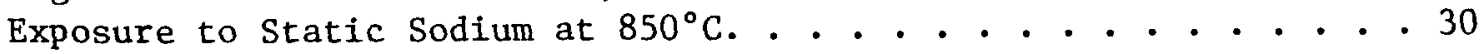


19. Sample of Duro Fireclay Acid Brick before and after Exposure to

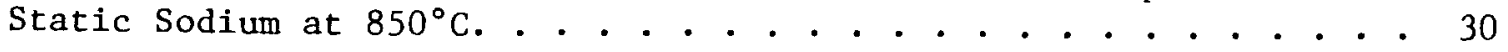

20. Sample of Varnon BF Hard Burned Super Duty Fireclay before and

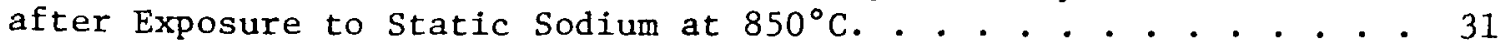

21. Magnesia-Alumina Based Material, $X-317$, before and after Exposure to Boiling Sodium . . . . . . . . . . . . . . . . . . . 32

22. Samples of X-317: Unexposed Sample and Sample after Exposure to Boiling Sodium . . . . . . . . . . . . . . . . . . . . . . 32

23. Magnesia Based Mixed Refractory, C-104, before and after Exposure to Boiling Sodium. . . . . . . . . . . . . . . . 33

24. Magnesia Based Mixed Refractory, RFG, before and after Exposure to Boiling Sodium ..... . . . . . . . . . . . . . 33

25. Alumina-Zirconia Mixed Refractory, UNICOR I, before and after Exposure to Boiling Sodium. . . . . . . . . . . . . . . 34

26. Zirconia-Silica Mixed Refractory, ZS 1300, before and after Exposure to Boiling Sodium. . . . . . . . . . . . . . . . . 34

27. High-density Graphite Brick before and after Exposure to Boiling Sodium. . . . . . . . . . . . . . . . . . 36

28. Sample of ATJ Graphite before and after Exposure to Static Sodium at $850^{\circ} \mathrm{C}$. . . . . . . . . . . . . . . . . . . 36

29. Reactor Grade Graphite, AGOT, before and after Exposure to Static Sodium at $850^{\circ} \mathrm{C}$. . . . . . . . . . . . . . . 37

30. Sample of FC-14 Graphite before and after Exposure to Static Sodium at $850^{\circ} \mathrm{C}$. . . . . . . . . . . . . . . . . 37

31. Vitreous Carbon Rod before and after Exposure to Static Sodium at $850^{\circ} \mathrm{C}$. . . . . . . . . . . . . . . . 38

32. Boron Carbide $\left(\mathrm{B}_{4} \mathrm{C}\right)$ Rod before and after Exposure to Static Sodium at $850^{\circ} \mathrm{C}$...................... . . . 38

33. Tantalum Rod before and after Exposure to Static Sodium at $850^{\circ} \mathrm{C}$. 39

34. Quartz Tube before and after Exposure to Static Sodium at $850^{\circ} \mathrm{C}$. 39

35. Beryllia Crucible before and after Exposure to Static Sodium at $850^{\circ} \mathrm{C}$. . . . . . . . . . . . . . . . . . 40

36. Thoria Rod before and after Exposure to Static Sodium at $850^{\circ} \mathrm{C}$. . 40 


\section{LIST OF TABLES}

No.

Title

$\underline{\text { Page }}$

1. Commercial Refractories Used in Sodium Compatibility Experiments. . 2

2. Results of Materials Interaction Tests with Sodium. . . . . . . 8 


\section{INTERACTIONS OF CERTAIN REFRACTORY MATERIALS WITH SODIUM}

\section{by}

J. K. Fink, J. J. Heiberger, R. Kumar, R. A. Blomquist, L. Leibowitz, E. S. Sowa, $\mathrm{J}$. R. Pavlik, and L. Baker, Jr.

\section{ABSTRACT}

Commercial refractories of alumina, magnesia, zirconia, and silica, as well as samples of graphite, thoria, beryllia, boron carbide, and quartz, were tested for compatibility with high-temperature and boiling sodium. Samples were exposed either to static sodium at $850^{\circ} \mathrm{C}$ for five hours or to boiling sodium for about an hour. Graphite, thoria, beryllia, boron carbide, and refractories with high alumina or magnesia contents, but with low silica and chromic oxide contents, were found to be compatible with hightemperature and boiling sodium. Sample compatibility with sodium decreased with an increase in the silica content of the sample. Samples with large silica content failed completely. Bricks with high zirconia content did not withstand exposure to boiling sodium, but high-fired zirconia crucibles appeared to be in good condition bricks, the results of the ANL experiments with refractory bricks are in good agreement with those obtained in sodium compatibility experiments done at Westinghouse Advanced Reactors Division.

\section{INTRODUCTION}

Various systems have been proposed for ex-reactor core retention following a hypothetical core-disruptive accident in a liquid metal fast breeder reactor (LMFBR). As a consequence of such an accident, the reactor vessel may fail, releasing fuel and sodium coolant to the reactor cavity. The proposed coreretention systems include stable barriers, sacrificial barriers, and cooled liners and trays. ${ }^{1,2}$ Stable and sacrificial barriers would use refractory materials, such as graphite, refractory metals, and ceramics, whereas liners and trays would generally be made of steel. In support of the sacrificial bed concept, some studies have been carried out to assess the interaction of fuel debris with basaltic rock, ${ }^{3}$ as well as with engineered beds of basalt, alumina, magnesia, urania, and thoria. ${ }^{2}, 4$ However, the feasibility of using these materials as beds will depend on their compatibility with high-temperature sodium. Little data are available on the compatibility of refractory ceramics with sodium. Some work has been done on the compatibility of refractories with liquid metals in connection with MHD systems, ${ }^{5}$ and some experiments have been performed on the compatibility of basalt with sodium. ${ }^{6}$ 
To provide information on the compatibility of materials proposed for core-retention systems with sodium at high temperatures, experiments were performed simultaneously at Argonne National Laboratory (ANL) and at Westinghouse Advanced Reactors Division (WARD). 7 Commercially available brick samples of refractories of magnesia, alumina, zirconia, and mixed ceramic oxides were obtained by WARD for both groups of experiments. In addition to the refractory bricks obtained from WARD, samples of graphite, tantalum, boron carbide, and quartz and refractories of thoria, beryllia, alumina, and zirconia were obtained from other sources and tested at ANL. The manufacturers of the various samples are given in Table 1 . The materials tested were in the form of small rectangular bricks, small high-fired crucibles, or rods.

Table 1. Commercial Refractories Used In Sodium Compatibility Experiments

\begin{tabular}{|c|c|}
\hline Manufacturer & Sample Description or Tradename \\
\hline Corhart Refractories Co. & $\begin{array}{l}\text { A-414 } \\
\text { C-104 } \\
\text { RFG } \\
\text { SR-504C } \\
\text { UNICOR I } \\
\text { X-317 } \\
\text { ZS } 1300\end{array}$ \\
\hline Harbison Walker Refractories Co. & $\begin{array}{l}\text { Duro Fireclay Acid Brick } \\
\text { Harklase } \\
\text { HW Corundum } \\
\text { HW Magnesite } \\
\text { HW Ruby } \\
\text { Korundal XD } \\
\text { Oxibak H } \\
\text { Varnon BF Super Duty Fireclay }\end{array}$ \\
\hline Norton Co. & $\begin{array}{l}\text { AH-199B } \\
\text { AN-199B } \\
\text { Crucible of Norton Mix Z-302 } \\
\text { MN 197 } \\
\text { Thoria Rod } \\
\text { ZH 192A } \\
\text { ZH 392C }\end{array}$ \\
\hline Pure Carbon Co. & FC-14 \\
\hline Union Carbide Corporation & $\begin{array}{l}\text { AGOT Graphite } \\
\text { ATJ Graphite }\end{array}$ \\
\hline
\end{tabular}


The major constituents--MgO, $\mathrm{Al}_{2} \mathrm{O}_{3}, \mathrm{ZrO}_{2}$, and $\mathrm{SiO}_{2}-$ of the refractories selected for the experiments satisfy the criterion for thermodynamic stability in sodium. The criterion for thermodynamic stability of a refractory oxide in an alkali metal is that the free energy of formation of the refractory oxide must be less (more negative) than that of the corresponding alkali metal oxide. Since this criterion for thermodynamic stability is a necessary but not a sufficient condition for the ceramic's compatibility with sodium, ${ }^{5}$ and since the refractories tested are not chemically pure, their stability in sodium is not easily predicted. The presence of other substances in the ceramics and in the binders used in fabrication, as well as the method of fabrication, affects the capability of the refractories to survive exposure to sodium at high temperatures.

Two different series of experiments were performed at ANL. In one series, samples were exposed to static sodium at $850^{\circ} \mathrm{C}$ for five hours, and in the other series, samples were immersed in boiling sodium for about one hour. The first series of experiments simulated reactor accident conditions which would result in the sample material being exposed to high-temperature sodium for several hours. In the second series of experiments, the test samples were exposed to more severe conditions, which better represented reactor accident conditions that would cause sodium to invade the ceramic structure and would then result in the sodium being heated by overlying and adjacent heat-generating pools. In both series, the samples were examined visually after they had been exposed to sodium. To determine their mechanical strength after sodium exposure, some of the surviving samples, that is, the samples that remained more or less physically intact, were crushed with a standard laboratory press, and the crushing strength of the exposed samples was compared with the crushing strength of unexposed samples of the same materials. The weight of other surviving samples was determined after the sodium had been removed from the samples with ethyl alcohol and water.

At WARD, samples of the commercially available refractory bricks of alumina, magnesia, zirconia, and various mixed ceramic oxides and commercial ramming cements were immersed in boiling sodium for one to four hours. ${ }^{7}$ After sodium exposure, the sodium was removed from the samples by vacuum distillation. A visual examination of the samples was followed by a weight loss determination.

\section{DESCRIPTION OF APPARATUS AND EXPERIMENTAL PROCEDURE}

Before the samples were exposed to sodium, they were physically characterized as to weight, density, porosity and dimensions, and then were photographed. The samples were in the form of rectangular bricks, about $1.5 \mathrm{~cm}$ by $2 \mathrm{~cm}$ by $3 \mathrm{~cm}$ or high-fired crucibles, $1 \mathrm{~cm} \mathrm{ID,} 1.5 \mathrm{~cm} \mathrm{OD}$, and about $2.5 \mathrm{~cm}$ high, or rods approximately $2.5 \mathrm{~cm}$ in length.

Following the physical characterization of a sample, it was either exposed to static sodium at $850^{\circ} \mathrm{C}$ for five hours, or immersed in boiling sodium for one hour. The experimental apparatus and procedure for the two types of tests are described below. 
A. Exposure to Static Sodium at $850^{\circ} \mathrm{C}$

The loading of the samples into the test capsules was carried out in an argon atmosphere glove box. Each sample was placed in a 5-cm long, stainless steel capsule made from 1-in. Sch 40 pipe with a welded bottom. In the case of rods and bricks, a sufficient amount of reagent-grade sodium was added to each capsule to allow, at the test temperature, two-thirds of the sample to be immersed in liquid sodium and one-third of the sample to remain in the vapor space. When a sample in the form of a crucible was tested, the crucible was filled with sodium, and sufficient sodium was added to the capsule so that it reached two-thirds of the way up the crucible at the test temperature. Each capsule was welded shut. Three capsules were stacked in a secondary container made from a 13.97-cm long piece of nominal 1-1/2-in. Sch 40 pipe fitted with end caps. For stability, the annular space between the capsules and the secondary container was packed with stainless steel helices. The secondary container was placed in the maximum temperature zone of a platinum-wound tube furnace having a heated zone $40 \mathrm{~cm}$ in length. A schematic diagram of the test assembly is shown in Fig. 1. Prior to the runs with sodium, the maximum temperature region and the temperature spread in the heated zone were determined, using a mockup of the capsule assembly. It was found that the temperature spread in the region of the sample capsules was less than $20^{\circ} \mathrm{C}$. The monitoring thermocouple located on the outside surface of the secondary container had been calibrated against a thermocouple placed inside the mockup capsule assembly.

In the sodium exposure experiments, the capsules were heated to $850^{\circ} \mathrm{C}$ and held at this temperature for five hours. The thermocouple located on the secondary container (see Fig. 1) was attached to a recorder to monitor the temperature at all times. Approximately three hours were required to reach the test temperature. After five hours at the test temperature, the furnace was turned off, and the capsules were allowed to cool below $98^{\circ} \mathrm{C}$ before returning them to the glovebox where they were cut open. After visually examining and photographing the contents of each capsule, the capsules containing the surviving samples were heated to me1t the sodium in order to remove the samples. After cooling, the sodium-coated refractory samples were crushed in an inert-atmosphere glovebox, using a standard hydraulic laboratory press. Unexposed samples of each refractory material were also crushed. The crushing strengths of exposed samples were compared with those of unexposed samples to determine if any loss of structural strength had occurred from the exposure to sodium.

\section{B. Exposure to Boiling Sodium}

The apparatus used for the compatibility tests with boiling sodium was also used for studies of heat transfer in volume-heated $\mathrm{UO}_{2}$-sodium debris beds and is described in detail elsewhere. ${ }^{8}$ Figure 2 shows a schematic diagram of the apparatus. 


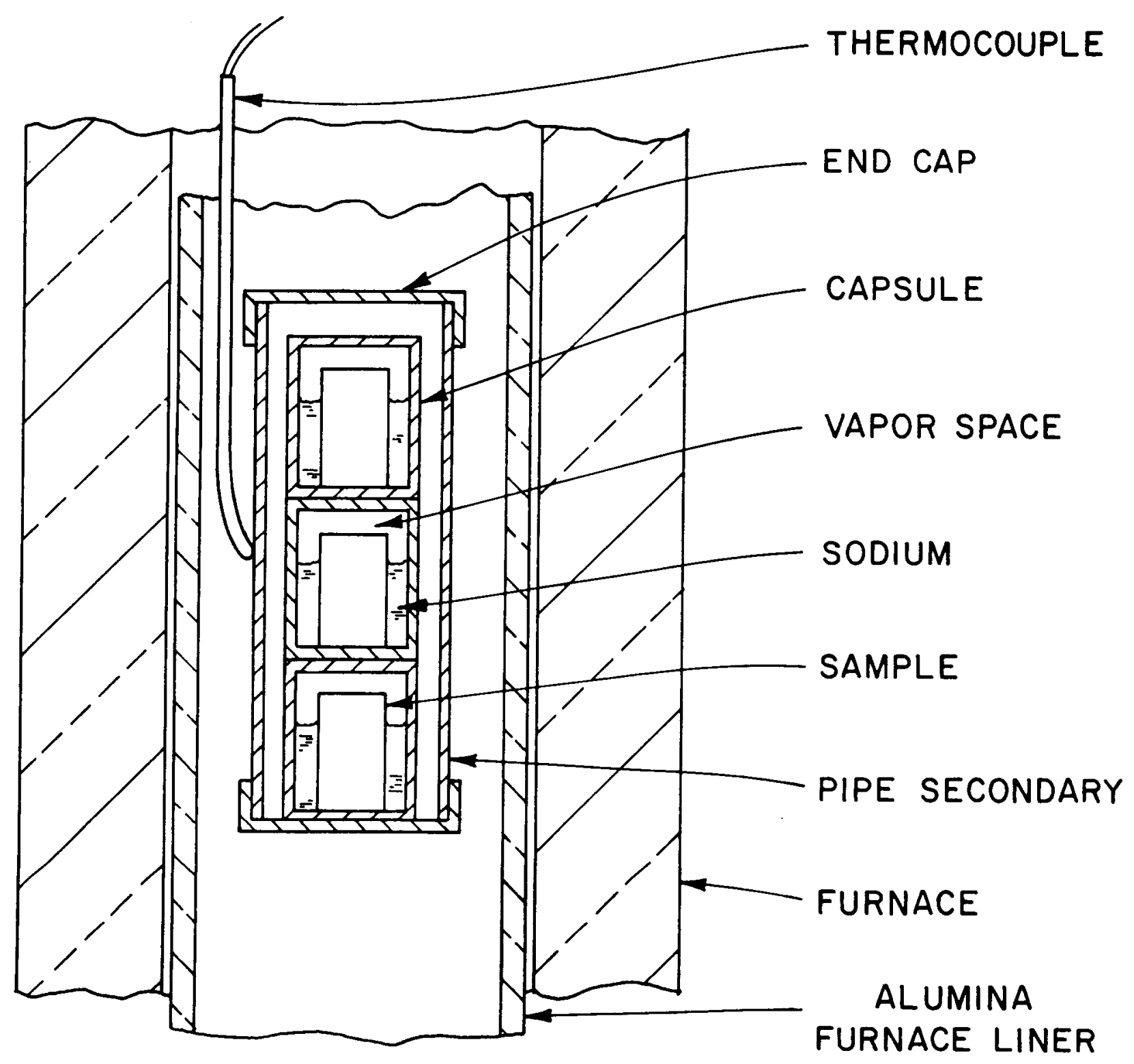

Fig. 1. Diagram of Test Assembly used for Static Sodium Exposure Tests 


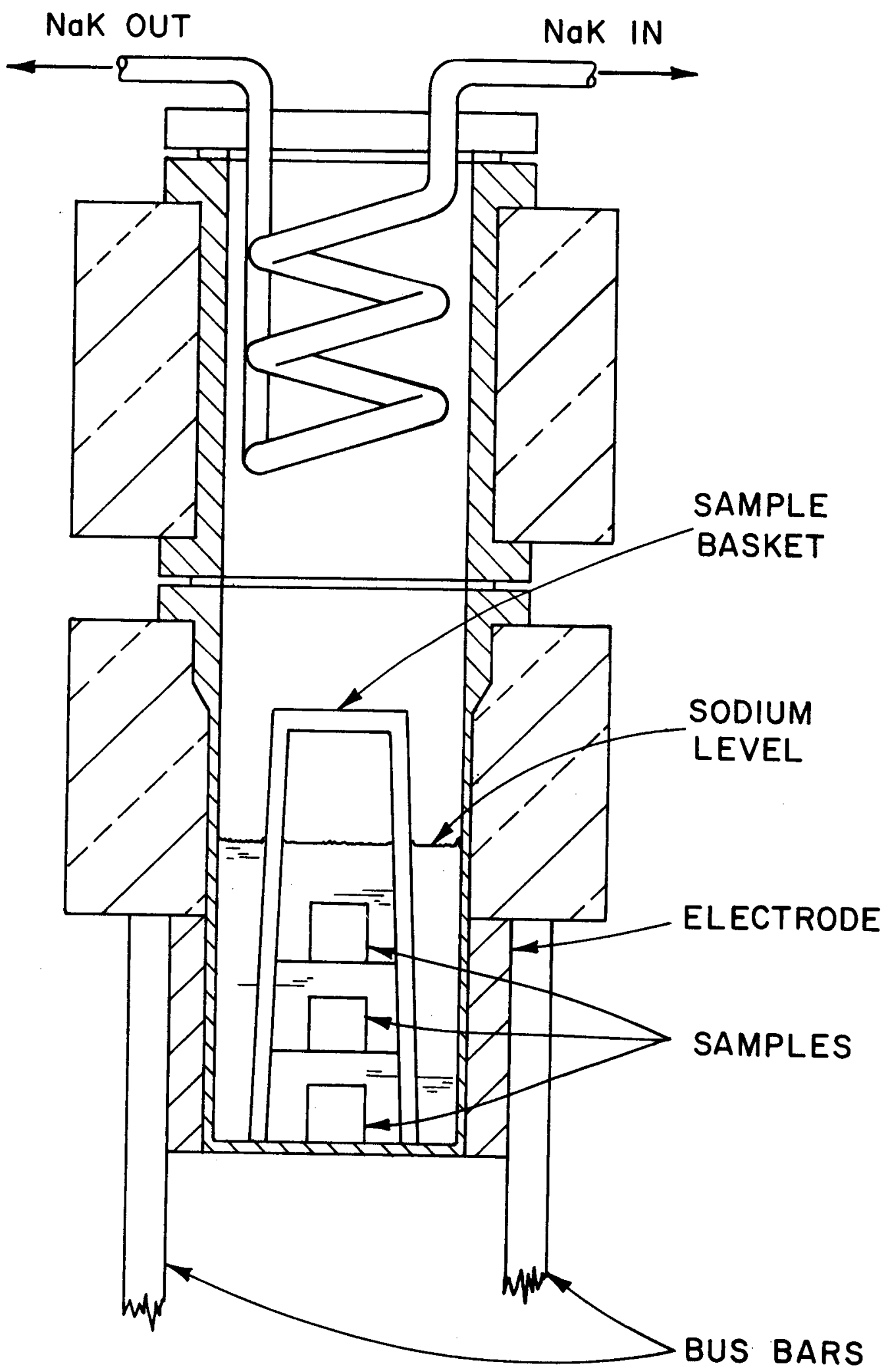

Fig. 2. Diagram of Apparatus used for Boiling Sodium Exposure Tests 
Three samples were placed in a three-tier stainless steel basket in an inert-atmosphere glovebox. This basket was inserted in the debris container and sufficient sodium was added so that the samples were completely immersed. The container was removed from the glovebox and mounted in the apparatus as in Fig. 2. The sodium was heated by passage of a 10,000 amp, $60 \mathrm{~Hz}$ current through the container by means of copper bus bars which were connected to a single-turn secondary of two transformers connected in parallel. By controlling the input voltage to the transformers, the samples could be subjected to various levels of specific power. The specific power generation is defined in this report as the heat energy developed per cubic centimeter of sodium and is expressed as cal/s $-\mathrm{cm}^{3}$ of sodium. This type of heating is significant in terms of its effect on the sodium that has permeated the interior of the sample. Passage of the current throught the internal sodium channels produced in situ boiling of sodium. Thus, the samples were exposed to conditions that were more severe than those that would have resulted from simple immersion of the samples in boiling sodium, since interior capillary channels retard the boiling of the sodium. Consequently, a degree of superheat is required before transformation of the liquid to a vapor. The sample interiors, then, are exposed to a higher temperature sodium, as well as to the potential mechanical disruptive effects of expanding vapor and of liquid metal being ejected through the channels. It is believed that this condition more closely represents reactor conditions under which sodium would invade the ceramic structure, and then be subjected to heating from overlying or adjacent heat-generating pools. Increased power levels were accommodated by increased refluxing between the pool and the NaK cooling coil.

After the samples had been exposed to sodium for one hour, they were allowed to cool to room temperature. The sample container was returned to the glovebox, and the samples were removed by reheating the sodium to the melting point. After the samples had been visually examined, sodium was removed using ethyl alcohol which reacted with the sodium to form sodium ethylate. The samples were then washed with water, dried, and reweighed to determine weight loss. The ethyl alcohol and water treatment caused some of the samples to suffer considerable breakdown. Such structural disintegration by this treatment has also been observed by Meacham. ${ }^{7}$ Consequent1y, this process of sodium removal was not used on later samples and no weight loss determinations were made. Thus, in subsequent experiments, crushing strength tests were made in an inert-atmosphere glovebox on sodium-coated samples.

\section{DISCUSSION OF RESULTS}

The results of exposure of the various samples to static sodium at $850^{\circ} \mathrm{C}$ for about five hours or to boiling sodium $\left(2883^{\circ} \mathrm{C}\right)$ for about one hour are summarized in Table 2. The samples tested are grouped in the table according to their composition. The values of each sample's density and effective porosity, which were determined prior to static sodium exposure, are also 1isted. In the last column in Table 2 are the results of crushing strength tests performed on sodium-coated samples after both types of sodium exposure experiments. In those cases where samples of the same refractory materials were subjected to both types of experiments, crushing strength tests were performed on the samples that survived exposure to static sodium. 
Table 2. Results of Materials Interaction Tests with Sodium

Sample Description or Tradename

Chemical Composition

Density $\left[\mathrm{g} / \mathrm{cm}^{3}\right]$

Effective

Porosity,

$[\%]$

$\frac{\text { Exposed to Boiling Sodium for about } 1 \mathrm{hr}}{\text { Power Level Weight Loss Physical Condition }}$ \begin{tabular}{lcc}
\hline Power Level & $\begin{array}{c}\text { Weight Loss } \\
{[\text { Physical Condition }} \\
{\left[\text { af } / \mathrm{s}-\mathrm{cm}^{3}\right]}\end{array}$ \\
\hline
\end{tabular} $[\%]$

Physical Condition after xposure to Static Sodium at $850^{\circ} \mathrm{C}$ for $5 \mathrm{hrs}$

Percent Crushing Strength af ter Sodium Exposure

Harklase

$$
\begin{array}{rl}
97.9 \% & \mathrm{MgO} \\
0.8 \% & \mathrm{SiO}_{2} \\
0.6 \% & \mathrm{CaO} \\
0.4 \% & \mathrm{Al}_{2} \mathrm{O}_{3}
\end{array}
$$

2.87

12.2

1.21

$0.2 \% \mathrm{Fe}_{2} \mathrm{O}_{3}$

MN 197

97. $9 \% \mathrm{MgO}$

$1.5 \% \mathrm{SiO}_{2}$

$95.7 \% \mathrm{MgO} \quad 2.95$

$2.4 \% \mathrm{CaO}$

$1.3 \% \mathrm{SiO}_{2}$

$0.3 \% \mathrm{SiO}_{2}$

$0.3 \% \mathrm{Al}_{2} \mathrm{O}$

$.3 \% \mathrm{Fe}_{2} \mathrm{O}_{3}$

HW Magnesite

$$
\begin{array}{rl}
92.6 \% & \mathrm{MgO} \\
4.4 \% & \mathrm{SiO}_{2} \\
1.7 \% & \mathrm{CaO} \\
0.8 \% & \mathrm{Fe}_{2} \mathrm{O}_{3} \\
0.5 \% & \mathrm{Al}_{2} \mathrm{O}_{3}
\end{array}
$$

10.9

Magnesia$$
\begin{aligned}
& \text { some crack } \\
& \text { (Fig. 3) }
\end{aligned}
$$

Good condition;

some. cracking

0.290$$
-1.7
$$

condition; no

apparent inter-

apparent inter

0.18
-2.3 Good condition;
some cracking
(Fig. 4)

1.21
0.18

Much cracking after sodium removal (Fig. 5)

Much cracking
after sodium removal
$94 \%$

apparent interaction (Fig. 3)

No apparent interaction (Fig. 4)

$78 \%$

No apparent interaction (Fig. 5)

${ }^{a}$ See Table 1 for the manufacturer of these refractories 
Table 2 (cont'd.)

$$
\begin{aligned}
99.5 \% \mathrm{Al}_{2} \mathrm{O}_{3} \\
0.25 \% \mathrm{~K}_{2} \mathrm{O}^{2}+ \\
\mathrm{Na}_{2} \mathrm{O} \\
0.09 \% \mathrm{Fe}_{2} \mathrm{O}_{3} \\
0.07 \% \mathrm{SiO}_{2} \\
0.09 \% \text { other } \\
\text { oxides }
\end{aligned}
$$

Sample Description or Tradename ${ }^{\mathrm{a}}$

Chemical Composition
Effective Density Porosity, $\left[\mathrm{g} / \mathrm{cm}^{3}\right]$

$[\%]$

\section{High-fired Crucible}

$v 100 \% \mathrm{Al}_{2} \mathrm{O}_{3}$
$99.8 \% \mathrm{AL}_{2} \mathrm{O}$ $0.1 \% \mathrm{Nar}(\mathrm{O})$ $0.07 \% \mathrm{TH} \mathrm{O}^{2}$

$0.03 \% \mathrm{Fe}_{2} \mathrm{O}_{3}$

AH 1.991

$$
\begin{array}{r}
99.5 \% \mathrm{Al}_{2} \mathrm{O}_{3} \\
0.25 \% \mathrm{~K}_{2} \mathrm{O}^{3}+ \\
\mathrm{Na}_{2} \mathrm{O} \\
0.09 \% \mathrm{Fe}_{2} \mathrm{O}_{3} \\
0.07 \% \mathrm{SiO}_{2} \\
0.09 \% \text { other } \\
\text { oxides }
\end{array}
$$

$\begin{array}{lll}3.8 \quad 0.47^{\mathrm{b}} & 1.0 & \begin{array}{l}\text { Alumina } \\ \text { Cood condition; no } \\ \text { apparent inter- } \\ \text { action (Fig. 7) }\end{array}\end{array}$

$--$

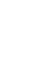

Exposed to Boiling Sodium for about $1 \mathrm{hr}$ Power Level Weight Loss Physical Condition $\left[\mathrm{ca} 1 / \mathrm{s}-\mathrm{cm}^{3}\right]$

N 199 B (0.06\%
less dense

than All $199 \mathrm{~B}$

bxposed for $82 \mathrm{~min}$ at this power level.

0.290

0.944 action (Fig. 7)

Physical Condition after Exposure to Static Sodiun at $850^{\circ} \mathrm{C}$ for $5 \mathrm{hrs}$ Sodium Exposure

$$
\begin{aligned}
& \text { Good condition; no } \\
& \text { apparent inter- }
\end{aligned}
$$

$$
\text { action (Fig. 9) }
$$

-- Good condicion; no apparent interaction (Fig. 1.0)

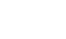

$$
\text { action (Fig. 1.0) }
$$

0.944
-- Grood condition; no apparent interaction (Fig. 11) 
Table 2 (cont'd.) Sample Description
or Tradename

HW Corundum

Alumina Brick

SR 504-C

Korundal XD
Chemical Composition
Density $\left[\mathrm{g} / \mathrm{cm}^{3}\right]$ $\left[\mathrm{cal} / \mathrm{s}-\mathrm{cm}^{3}\right] \quad[\%] \quad$ after Exposure

$$
\begin{gathered}
99.2 \% \mathrm{Al}_{2} \mathrm{O}_{3} \\
0.2 \% \mathrm{SiO}_{2} \\
0.2 \% \mathrm{Fe}_{2} \mathrm{O}_{3} \\
0.15 \% \mathrm{CaO} \\
0.15 \% \mathrm{Na}_{2} \mathrm{O} \\
+\mathrm{K}_{2} \mathrm{O}^{-} \\
\mathrm{Li}_{2} \mathrm{O} \\
0.1 \% \mathrm{TiO}_{2} \\
\text { (Trace) } \mathrm{MgO}^{2}
\end{gathered}
$$

$99 \% \mathrm{Al}_{2} \mathrm{O}_{3}$

$97.5 \% \mathrm{Al}_{2} \mathrm{O}$
$1.5 \% \mathrm{CaO}^{-}$

$0.4 \% \mathrm{Na}_{2} \mathrm{O}$

$0.4 \% \mathrm{Na}_{2}$
$0.2 \% \mathrm{~F}-$

$$
\begin{gathered}
90.8 \% \mathrm{Al}_{2} \mathrm{O}_{3} \\
8.5 \% \mathrm{SiO}_{2} \\
0.2 \% \mathrm{Fe}_{2} \mathrm{O}_{3} \\
0.15 \% \mathrm{Na}_{2} \mathrm{O} \\
+\mathrm{K}_{2} \mathrm{O}+ \\
\mathrm{Li}_{2} \mathrm{O} \\
0.1 \% \mathrm{TiO}_{2} \\
0.07 \% \mathrm{CaO} \\
0.07 \% \mathrm{MgO}
\end{gathered}
$$

Effective Porosity,
Exposed to Boiling Sodium for about 1. hr Power Level weight Loss Physical Condition Alumina (cont'd.)

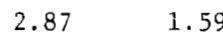

1.59

1.21

$$
-2.2
$$

Good

fair amount fair amoun$$
\text { spaliation }
$$

(Fig. 13)
Good condition

fair amount of spallation

$2.9 \quad--$

0.67

24

Some intergranular attack (Fig. 8)

Physical Condition after Exposure to Static Sodium at $850^{\circ} \mathrm{C}$ for $5 \mathrm{hrs}$

No apparent interaction (Fig. 13)

\subsection{0}

$--$

Good condition; no apparent interaction (Fig. 12)
$-$

$120 \%$

Some interaction; softening swelling, and cracking (Fig. 14)
Percent Crushing Strength after Sodium Exposure 
Table 2 (cont'd.)

Sample Description

Chemical

Composition

Density

$\left[\mathrm{g} / \mathrm{cin}^{3}\right]$

HW Ruby

$89.7 \% \mathrm{Al}_{2} \mathrm{O}_{3}$

$10.0 \% \mathrm{Cr}_{2} \mathrm{O}_{3}$

3.12

$0.1 \% \mathrm{SiO}_{3}$

$0.1 \% \mathrm{Fe}_{2} \mathrm{O}_{3}$

. $1 \% \mathrm{Na}_{5} \mathrm{O}$

$+\mathrm{K}_{2} \mathrm{O}$

(Trace) $\mathrm{CaO}$

(Trace) $\mathrm{CaO}$

(Trace) $\mathrm{llO}_{2}$

Effective Exposed to Boiling Sodium for about $1 \mathrm{hr}$

Purosity, Power Level Weight Loss physical Condition

$[\%]$

$\left(\mathrm{cal} / \mathrm{s}-\mathrm{cm}^{3}\right)$ $1 \%$ Alumina $\left(\operatorname{cont}^{\prime} \mathrm{d}\right.$.)

1.3 .3

0.20

disintegration

Physical Condition after Exposure to Static Sodium at $850^{\circ} \mathrm{C}$ for $5 \mathrm{hrs}$

Percent Crushing Strength after Sodium Exposure

ignificant interaction; sodium completely absorbed (Fig. 15)

\section{Zirconia}

\begin{tabular}{|c|c|}
\hline $\begin{array}{l}\text { 1hin-fired } \\
\text { crucible }\end{array}$ & $\left(z r O_{:}\right)$ \\
\hline $\begin{array}{l}\text { Crucible of } \\
\text { Norton Mix } \\
\text { z-302 (high- } \\
\text { fired, fine } \\
\text { grained) }\end{array}$ & $\begin{array}{c}92.0 \% \mathrm{Zro} \\
4.5 \% \mathrm{CaO}_{2} \\
1.5 \% \mathrm{HHO}_{2} \\
0.9 \% \mathrm{SiO}_{3} \\
0.6 \% \mathrm{Al}_{2} \mathrm{O}_{3} \\
0.3 \% \mathrm{TiO}_{3} \\
0.2 \% \mathrm{FeO}_{2}\end{array}$ \\
\hline
\end{tabular}

Exposed for $84 \mathrm{~min}$ at this power level

${ }^{d}$ Not crushed hecause of crucible form of sample $0.39^{c}$

$4 \cdot 0$

28
0.2

S1.ight crack

(Fig. 1.7)
No apparent interaction

(Fig. 18) 
Table 2 (cont'd.)

Sample Description or Tradename

Composition
Densicy $\underline{\left[\mathrm{g} / \mathrm{cm}^{3}\right]}$
Effective Porosity, P\%]
Exposed to Boiling Sodium for about $1 \mathrm{hr}$ Power Level Weight Loss Physical Condition $\left.[\mathrm{ca}] / \mathrm{s}-\mathrm{cm}^{3}\right] \ldots[\%$ after Exposure

Zirconia (cont'd.)

$4.5 \% \mathrm{CaO}$

$1.5 \% \mathrm{HfO}_{2}$

$0.9 \% \mathrm{SiO}_{2}$

$0.6 \% \mathrm{Al}_{2} \mathrm{O}_{3}$

$0.3 \% \mathrm{TiO}_{2}$

$0.2 \% \mathrm{Fe}_{2} \mathrm{O}_{3}$

ZH 192A (coarse grained, dense fused)

$92.0 \% \mathrm{ZrO}_{2}$ $4.5 \% \mathrm{CaO}$ $1.5 \% \mathrm{HfO}_{2}$

$0.9 \% \mathrm{SiO}_{2}$

$0.6 \% \mathrm{Al}_{2} \mathrm{O}_{3}$

$0.3 \% \mathrm{TiO}_{2}$

$0.2 \% \mathrm{Fe}_{2} \mathrm{O}_{3}$

Sintered fire

brick

$\left(\mathrm{ZrO}_{2}\right)$

$8.7 \% \mathrm{SiO}_{2}$

$32.0 \% \mathrm{Al}_{2} \mathrm{O}_{3}$

$6 \% \mathrm{Na}_{2} \mathrm{O}$ $+\mathrm{K}_{2} \mathrm{O}$

$\mathrm{Li}_{2} \mathrm{O}$

$2.7 \% \mathrm{Fe}_{2} \mathrm{O}$

$2.1 \% \mathrm{TiO}_{2}$

Physical Condition after Exposure to Static Sodiu at $850^{\circ} \mathrm{C}$ for $5 \mathrm{hrs}$

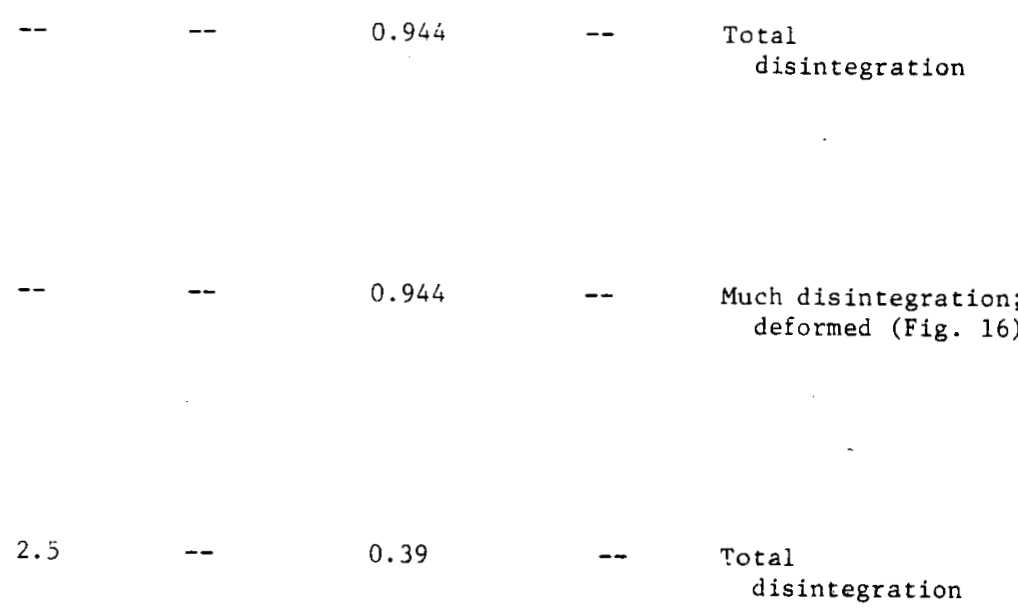

0.944 -- Total Much disintegration
deformed (Fig. 16)

0.944

0.39

Total

disintegration

ro Fireclay Acid Brick
2.31
4.0
Mixed Ceramic Oxides

0.115

Total

disintegration
Percent Crushing Strength after Sodium Exposure

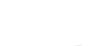


Table 2 (cont'd.)

Sample Description Chemical Density Porosity, Power Level Weight Loss Physical Condition

Composition

$\left[\mathrm{g} / \mathrm{cm}^{3}\right.$

$5.2 .1 \% \mathrm{SiO}_{2}$
$43.0 \% \mathrm{Al}_{2} \mathrm{O}_{3}$

$2.4 \% \mathrm{TiO}_{2}$

$+\mathrm{K}_{2} \mathrm{O}+$

$0.3 \%$

$0.3 \% \mathrm{CaO}$

$0.3 \% \mathrm{MgO}$

$x-317$

$67.0 \% \mathrm{MgO}$

$31.0 \% \mathrm{Al}_{2} \mathrm{O}_{3}$

$0.8 \% \mathrm{Fe}_{2} \mathrm{O}_{3}$

$0.5 \% \mathrm{~S}_{2} \mathrm{O}_{2}$

$0.5 \% \mathrm{CaO}$

$C-1.04$

$56.5 \% \mathrm{MgO}$

$20.0 \% \mathrm{Cr}_{2} \mathrm{O}_{3}$

$10.5 \% \mathrm{FeO}$

$8.0 \% \mathrm{Al}_{2} \mathrm{O}_{3}$
$2.5 \% \mathrm{S1O}_{3}$

$2.5 \% \mathrm{S1O}_{2}$
$1.5 \% \mathrm{TiO}_{2}$

$0.5 \% \mathrm{CaO}$

2.34

4.0

0.115

$\%]$

hysical Condition

5 -- Total

\author{
0.290 \\ 0.130
}

$--$

cood condition:

action (Fig. 23)
Physical Condition after xposure to Static Sodium

Percent Crushing Strength after at $850^{\circ} \mathrm{C}$ for $5 \mathrm{hrs}$

Sodium Exposure

Significant interaction;

sodium completely

absorbed (Fig. 20)
no apparent inter-
action (Fig. 21)

no apparent inter-

No comparison could be made because the retained sample was non-representative 
Table 2 (cont'd.)

Sample Description or Tradename

Chemical Composition

Density $\left[\mathrm{g} / \mathrm{cm}^{3}\right]$

Effective Porosity,

$[\%]$

RFG

$$
\begin{array}{rl}
56.0 \% & \mathrm{MgO} \\
20.0 \% & \mathrm{Cr}_{2} \mathrm{O}_{3} \\
11.0 \% & \mathrm{FeO} \\
8.0 \% & \mathrm{Al}_{2} \mathrm{O}_{3} \\
2.5 \% & \mathrm{SiO}_{2} \\
1.5 \% & \mathrm{TiO}_{2} \\
0.5 \% & \mathrm{CaO} \\
0.3 \% & \mathrm{~F}_{2}
\end{array}
$$

UNICOR I$$
46.4 \% \mathrm{Al}_{2} \mathrm{O}_{3}
$$$$
40.4 \% \mathrm{ZrO}_{2}
$$$$
2.9 \% \mathrm{SiO}_{2}
$$$$
1.1 \% \mathrm{Na}_{2} \mathrm{O}
$$$$
0.1 \% \mathrm{Fe}_{2} \mathrm{O}_{3}
$$$$
0.1 \% \mathrm{TiO}_{2}
$$

Exposed to Boiling Sodium for about $1 \mathrm{hr}$ Weight Loss Physical Condition $[\mathrm{ca}] / \mathrm{s}-\mathrm{cm}^{3}$ ] $[\%]$ af ter Exposure

Physical Condition after Exposure to Static Sodium at $850^{\circ} \mathrm{C}$ for $5 \mathrm{hrs}$

Percent Crushing treng th af ter Sodium Exposure

Mixed Ceramic Oxides (cont'd.)

0.130

Surface erosion

(Fig. 24)

0.167

$$
\begin{array}{ll}
\text { cracked into } 2 \\
\text { pieces (Fig. 25) }
\end{array}
$$$$
\text { -- Deformed and }
$$

$65.9 \% \mathrm{ZrO}_{2}$

$32.16 \% \mathrm{SiO}_{2}$

$1.28 \% \mathrm{TiO}_{2}$

$0.22 \% \mathrm{Al}_{2} \mathrm{O}_{3}$

$0.19 \% \mathrm{CaO}$

$0.12 \% \mathrm{Fe}_{2} \mathrm{O}_{3}$

Vitreous Carbon

$100 \% \mathrm{C}$

1.4

$100 \% \mathrm{C}$ $\cdot 0.0$

$-$

0.54
0.167
-- Much disintegration and cracking (Fig. 26)

Graphites and Carbon
Graphite Brick

1.0

Slight surface
No apparent interaction (Fig. 31)
$34 \%$

powdering
(Fig. 27) 
Sample Description Chemical Density Porosity, Power level Weight Loss Physical Condition

ATJ Graphite

OT Graphite

(Reactor Grade)

$\mathrm{FC}-14$

(Reactor Grade)

Tancalum Rod

Quartz Rod
Composition

$\left[\mathrm{g} / \mathrm{cm}^{3}\right]$
Power Level

$\left[\mathrm{cal} / \mathrm{s}-\mathrm{cm}^{3}\right]$

$$
\text { [\% }
$$

after Exposure

Graphites and Carbon (cone'd.)

$100 \% \mathrm{C}$ (f
grained,
formed by

1.79

1. 0

molding)

$1.00 \% \mathrm{C}$

(formed by

extrusion)

$1.00 \% \mathrm{C}$

(formed by
molding)

0.91

$\mathrm{B}_{4} \mathrm{C}^{9}$

Ta

2.5

1.6 .5

$--$

1.63

4.8

0.0

$100 \% \mathrm{SiO}_{2}$
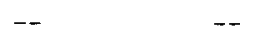

$-$

$-$

Control Materials

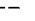$$
\text { -- }
$$$$
-
$$

Miscellaneous

Physical Condition after exposure to Static Sodium at $850^{\circ} \mathrm{C}$ for $5 \mathrm{hrs}$

No apparent interaction (Fig. 28)

No apparent interaction (Fig. 29)

No apparent interaction (Fig. 30)

No apparent interaction (Fig. 32)

No apparent interaction (Fig. 33)

Devitrified; total disintegration (Fig. 34

Percent Crushing Strength a ter Sodiurn Exposure
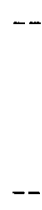

$-$

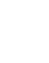

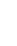


Table 2 (cont'd.)

Sample Description

or Tradename

Beryllia Crucible
Chemical

Composition

$9.5 \% \mathrm{BeO}$

$0.3 \% \mathrm{SiO}_{2}$

$0.2 \% \mathrm{MgO}$

$\sim 100 \% \mathrm{ThO}_{2}$
Effective

Density $\underline{\left[\mathrm{g} / \mathrm{cm}^{3}\right]}$

3.42
Exposed to Boiling Sodium for about $1 \mathrm{hr}$ ?ower Leve1 Weight Loss Physical Condition $\left[\mathrm{ca} 1 / \mathrm{s}-\mathrm{cm}^{3}\right] \quad[\%] \quad$ after Exposure

Miscellaneous (cont'd.)
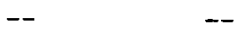

$--$
Physical Condition after xposure to Static Sodiu at $850^{\circ} \mathrm{C}$ for $5 \mathrm{hrs}$

No apparent interaction (Fig. 35)

No apparent interaction (Fig. 36)
Percent Crushing Strength af ter Sodium Exposure 


\section{A. Magnesia Samples}

Of the four refractories containing a large percentage of magnesia, three (Harklase, Oxibak $\mathrm{H}$, and $\mathrm{HW}$ Magnesite) were subjected to both types of tests. The fourth high-magnesia refractory, MN 197, was subjected only to the boiling sodium test. All the samples survived intact after exposure to sodium by either method. This is in agreement with the results for high-magnesia samples tested at WARD. ${ }^{7}$ Figures 3 through 5 show Harklase, Oxibak H, and HW Magnesite after exposure to boiling sodium both before and after sodium removal. These three samples were firm and in good condition before sodium removal. After sodium removal by the ethyl alcohol and water treatment previously described, cracking was evident. HW Magnesite underwent much cracking and lost some of its structural integrity, whereas Harklase and Oxibak $\mathrm{H}$ experienced some cracking, but remained intact. This cracking is quite likely due to the removal of sodium compounds, such as sodium silicates, that may have formed. Different samples of Harklase and HW Magnesite were exposed to high-power and low-power levels in the sodium boiling experiments. No difference in the final condition of the samples was observed for the two power leve1s. MN 197 survived intact (Fig. 6).

All of the high magnesia samples treated by exposure to sodium at $850^{\circ} \mathrm{C}$ for five hours survived intact with no apparent interaction. Figures 3 through 5 show the samples before and after exposure to sodium in the static tests. It is interesting to note that the fine geometric imperfections on the surface of the samples originally present are still visible under the sodium coating. It should also be noted that the walls of the stainless steel capsules are wetted with clean sodium, thereby indicating that no extensive interaction occurred.

The crushing strength of all the magnesia samples was diminished by exposure to sodium. However, in the case of Harklase, which contained the smallest percentage of silica, the decrease in crushing strength was negligible. From Table 2, it appears that as the percentage of silica increases, the residual crushing strength is decreased.

\section{B. Alumina Samples}

Three samples with high alumina contents, HW Corundum, Korundal XD, and HW Ruby, were tested by both experimental procedures. The remaining highalumina samples (a high-fired alumina crucible, A-414, AH 199B, AN 199B, SR 504-C, and a 99\% alumina brick from FFTF) were tested only by exposure to boiling sodium. The crucible of high-fired recrystallized alumina was boiled in sodium for about $1-1 / 2$ hours and survived in excellent condition, with only a slight darkening and a slight weight loss (see Fig. 7). Although a section of a $99 \%$ aluminabrick survived substantially intact, some intergranular attack was apparent (Fig. 8), and about one-fourth of the sample was lost by dissolution in sodium.

The high-alumina samples containing little or no silica and no chromic oxide $\left(\mathrm{Cr}_{2} \mathrm{O}_{3}\right), \mathrm{A}-414, \mathrm{AH} 199 \mathrm{~B}, \mathrm{AN} 199 \mathrm{~B}, \mathrm{SR}-504 \mathrm{C}$, and HW Corundum, survived sodium exposure in good condition, with no apparent interaction (see Figs. 


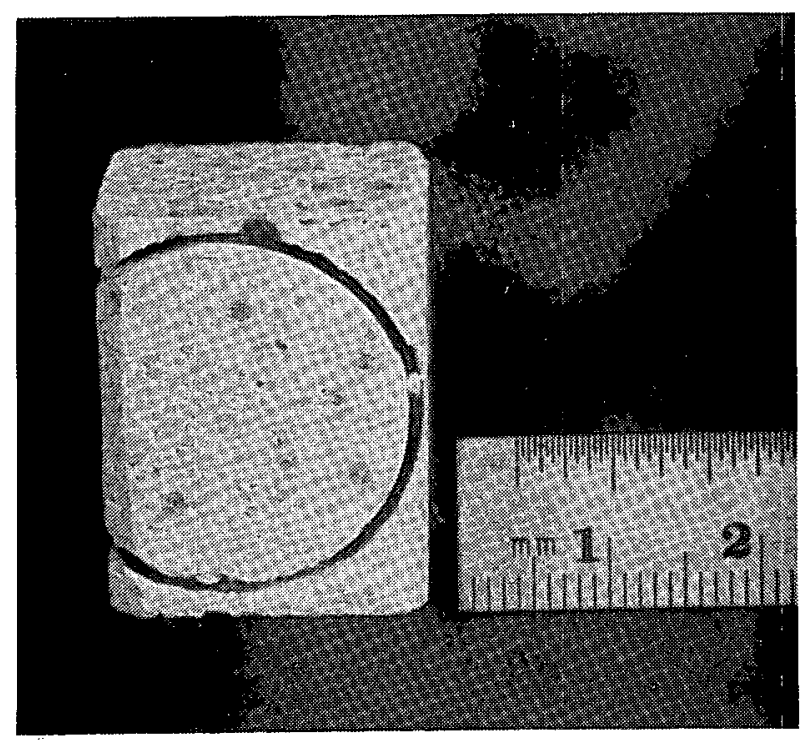

a. Before Sodium Exposure

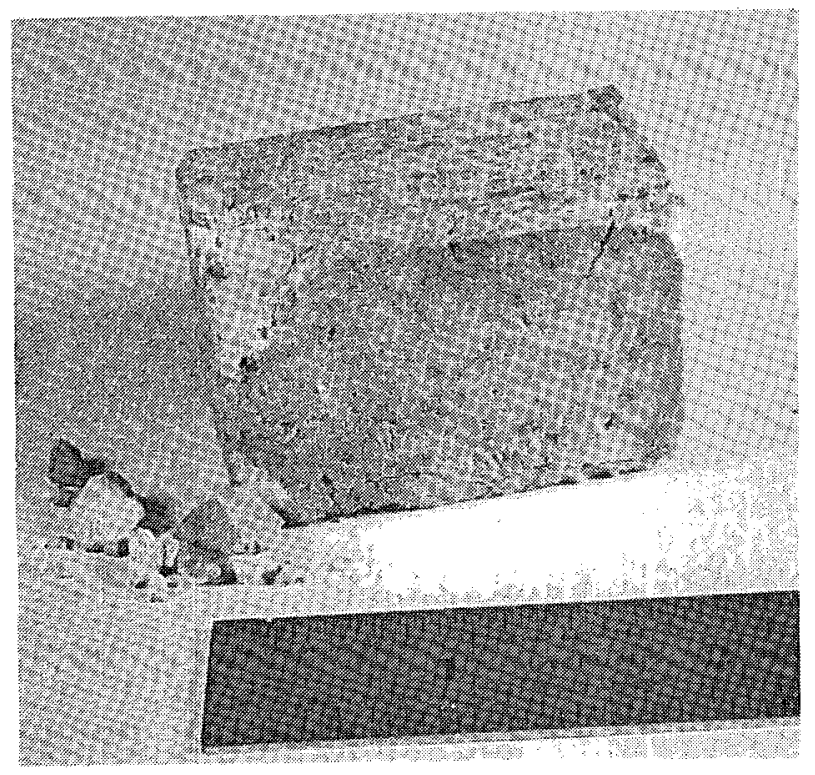

c. After Exposure to Boiling Sodium; After Sodium Removal

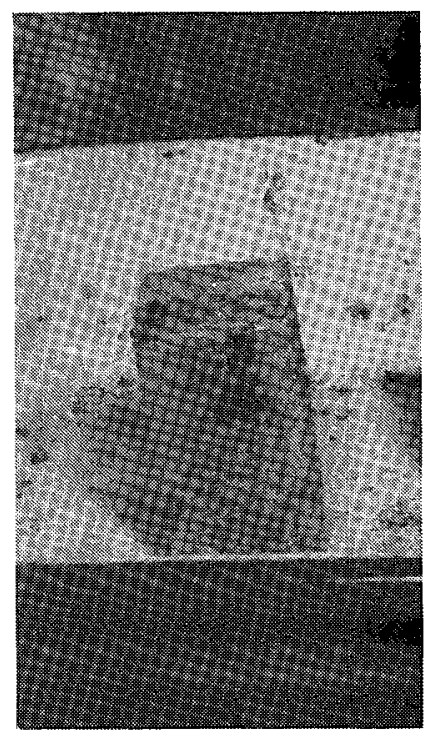

b. After Exposure to Boiling Sodium; Before Sodium Removal

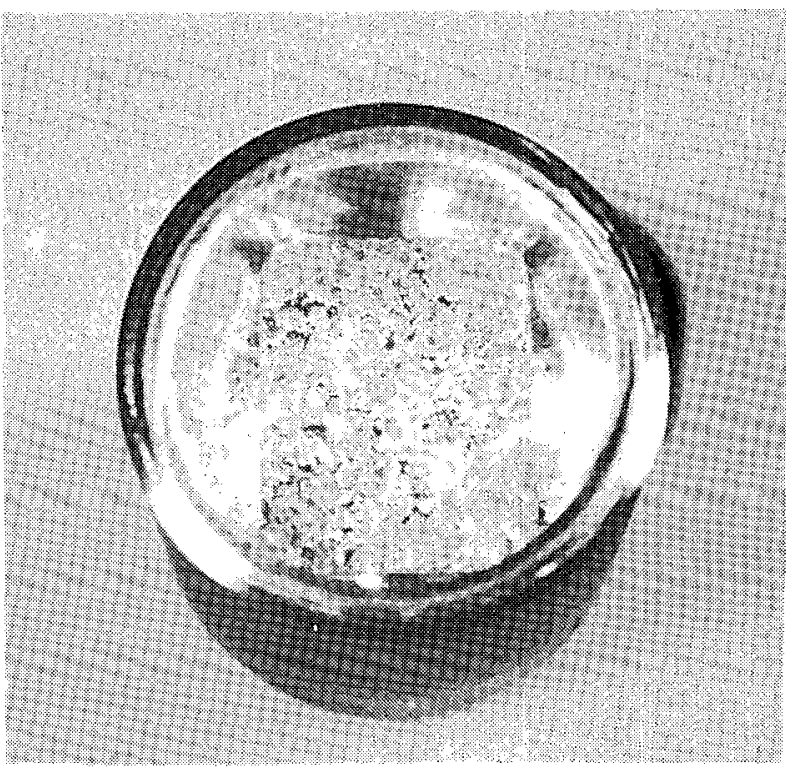

d. After Exposure to Static Sodium at $850^{\circ} \mathrm{C}$

Fig. 3. High Magnesia Material, Harklase, before and after Sodium Exposure 


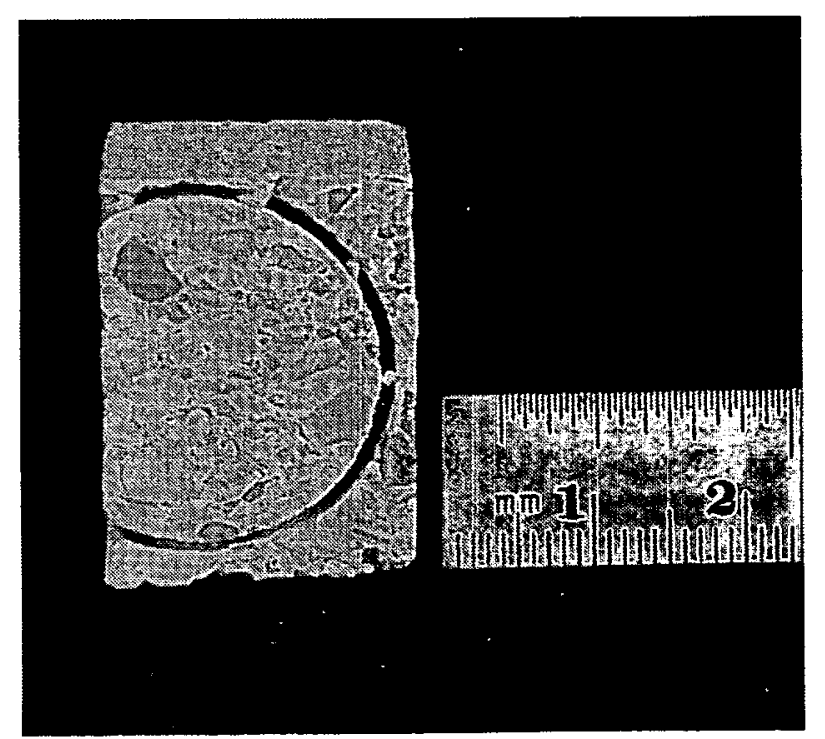

a. Before Sodium Exposure

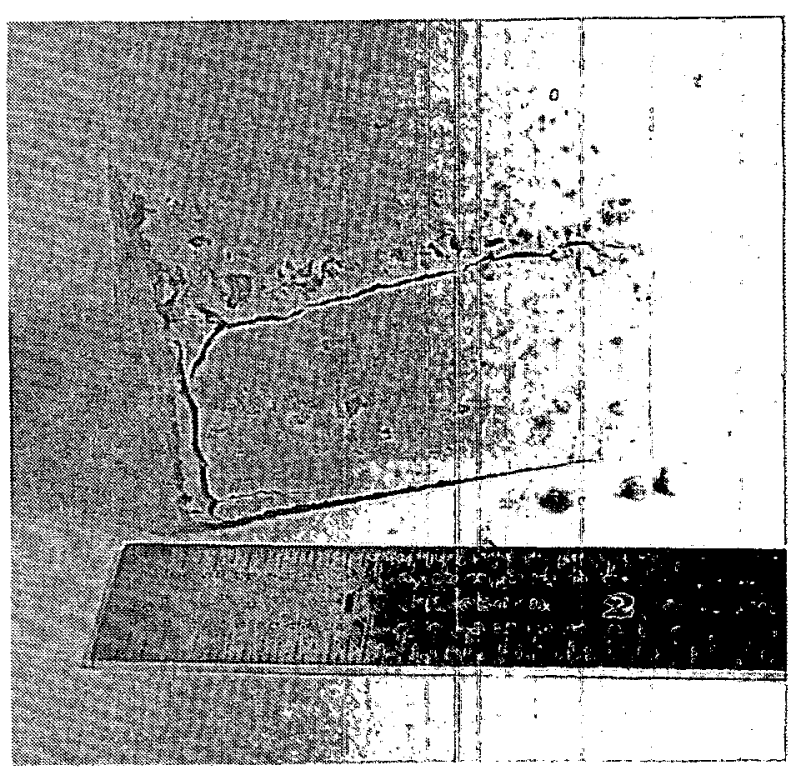

c. After Exposure to Boiling Sodium; After Sodium Removal

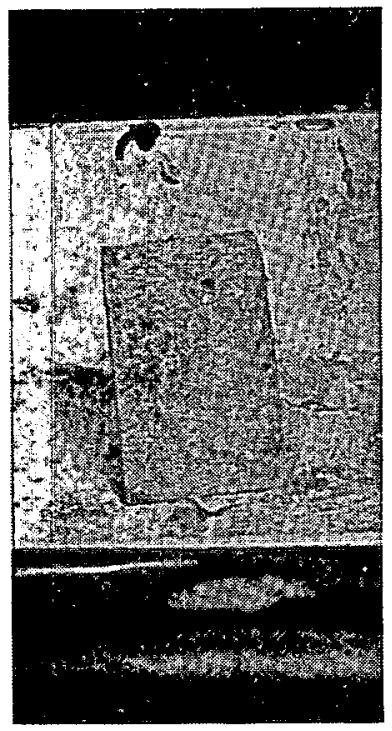

b. After Exposure to Boiling Sodium; Before Sodium Removal

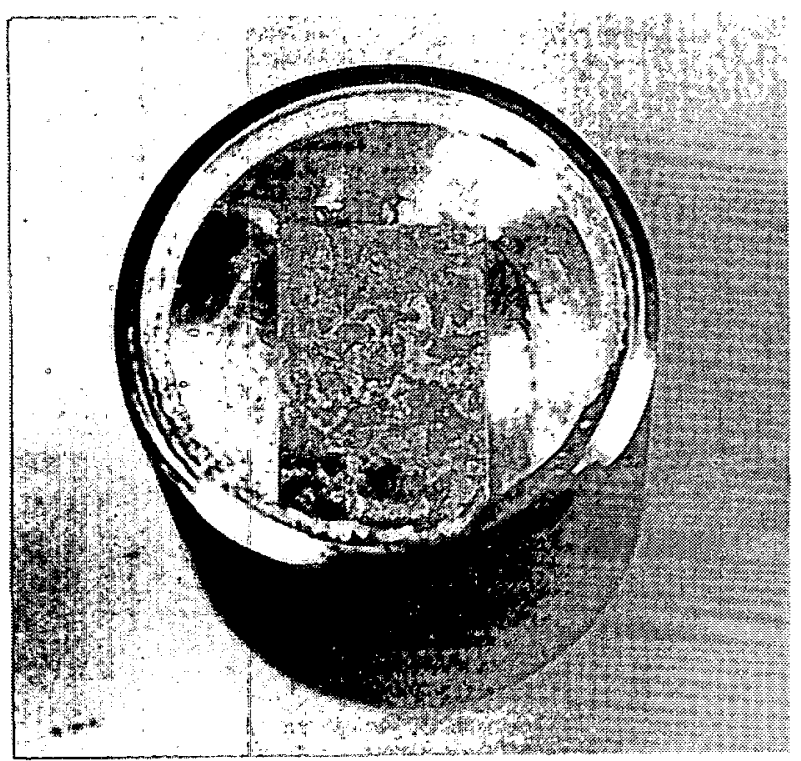

d. After Exposure to Static Sodium at $850^{\circ} \mathrm{C}$

Fig. 4. High Magnesia Material, Oxibak $\mathrm{H}$, before and after Sodium Exposure 


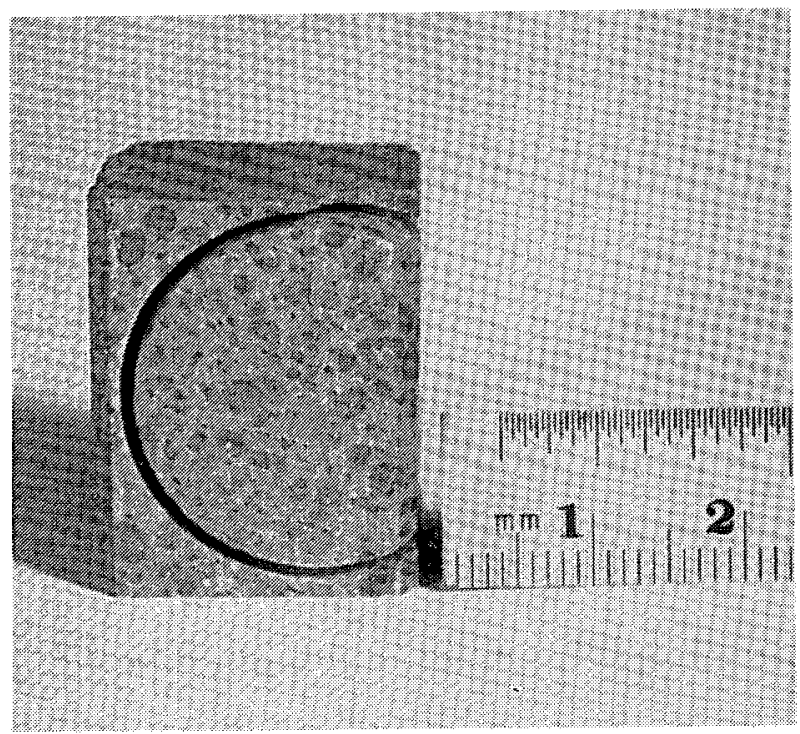

a. Before Sodium Exposure

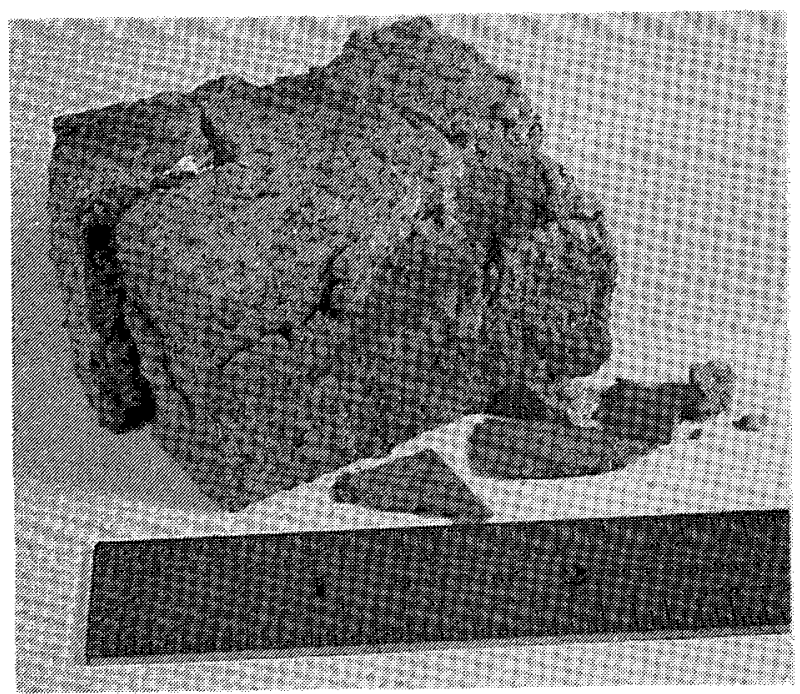

c. After Exposure to Boiling Sodium; After Sodium Removal

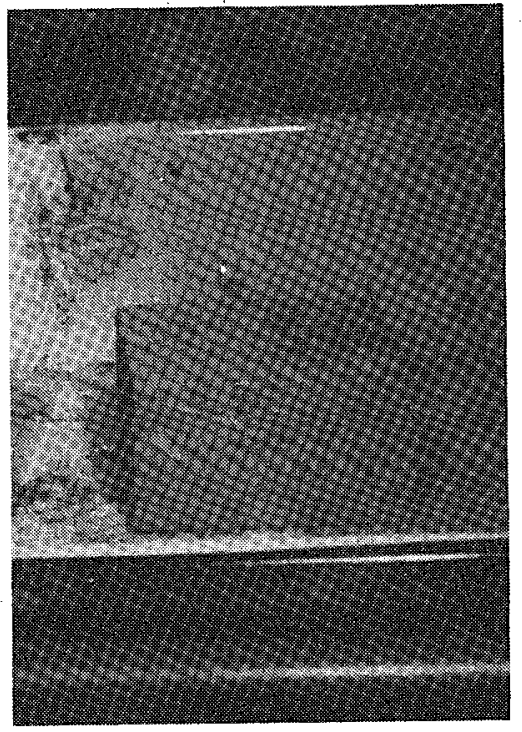

b. After Exposure to Boiling Sodium; Before Sodium Removal

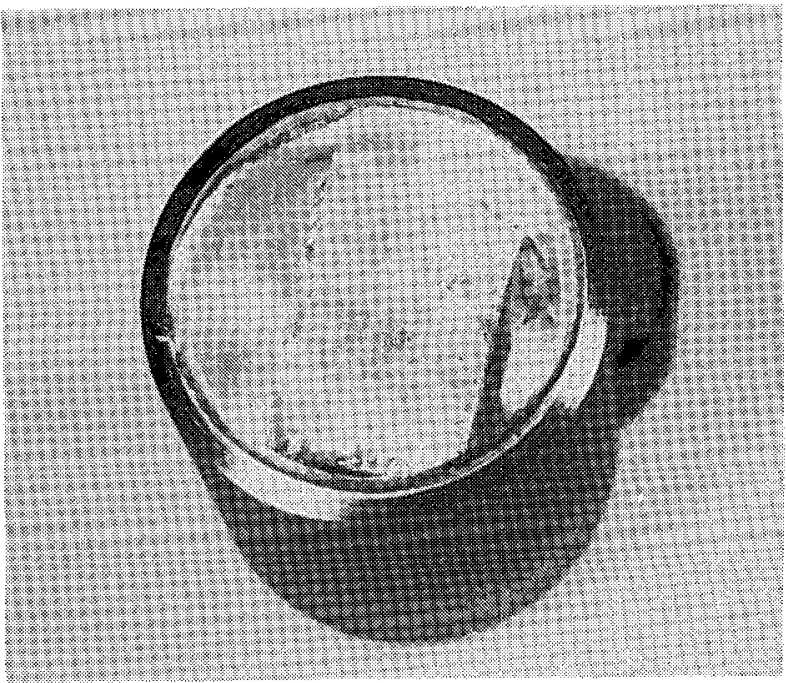

d. After Exposure to Static Sodium at $850^{\circ} \mathrm{C}$

Fig. 5. High Magnesia Material, HW Magnesite, before and after Sodium Exposure 


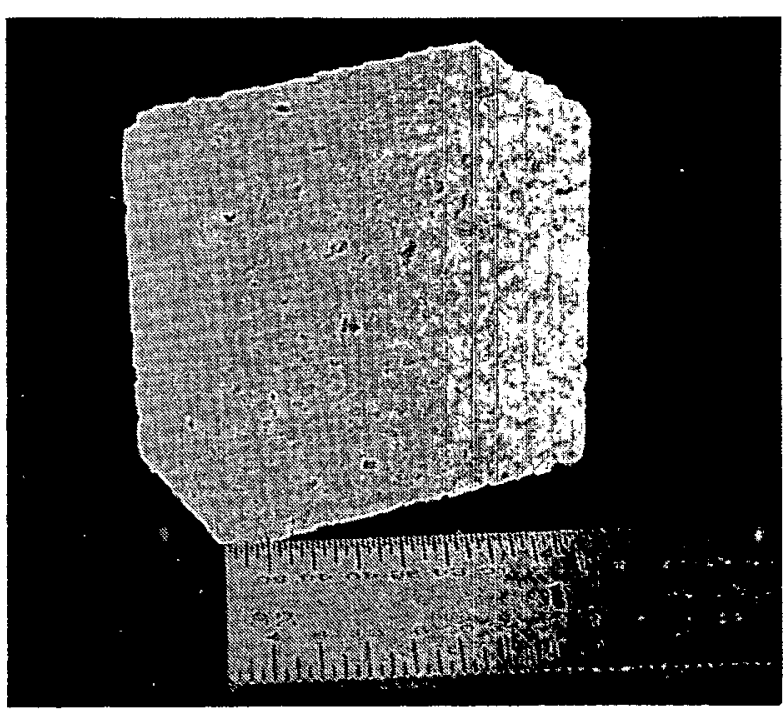

a. Before Sodium Exposure

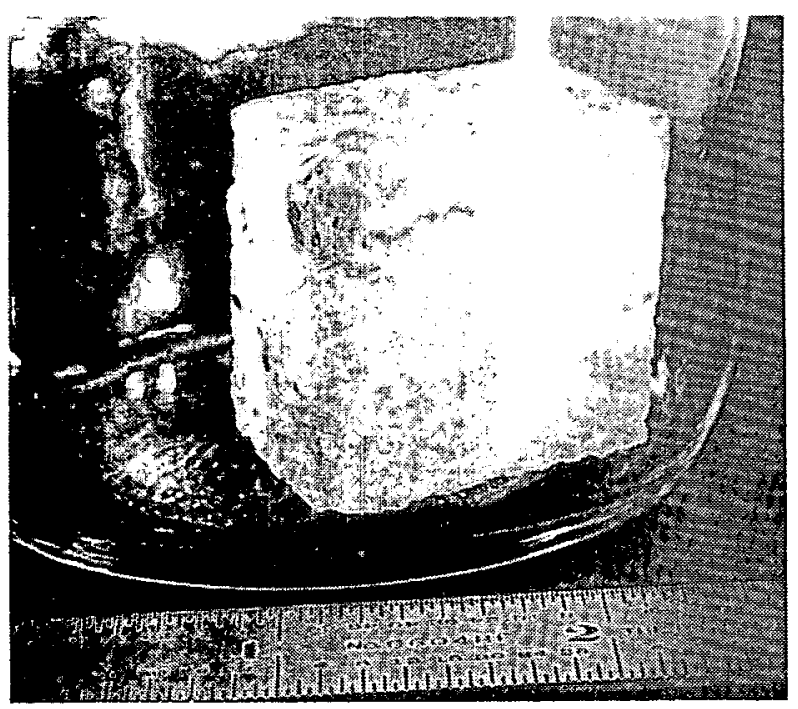

b. After Exposure to Boiling Sodium; Before Sodium Removal

Fig. 6. High Magnesia Material, MN 197, before and after Exposure to Boiling Sodium

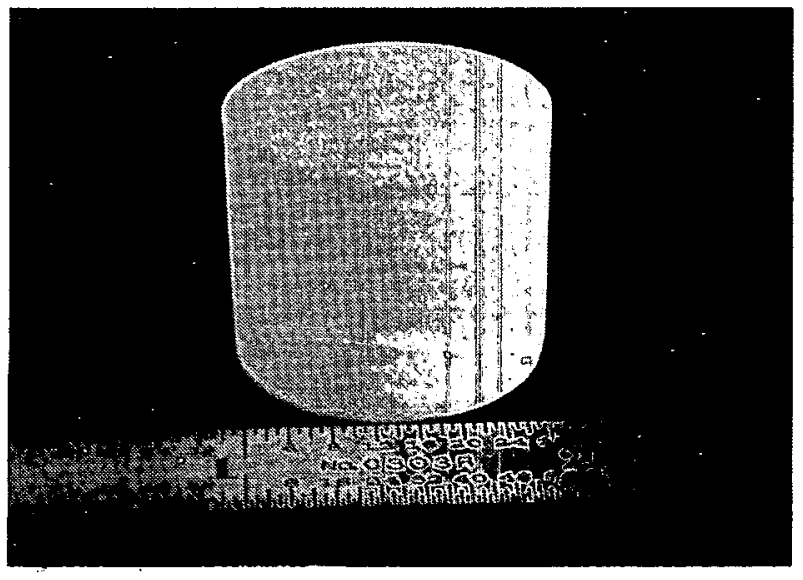

a. Before Sodium Exposure

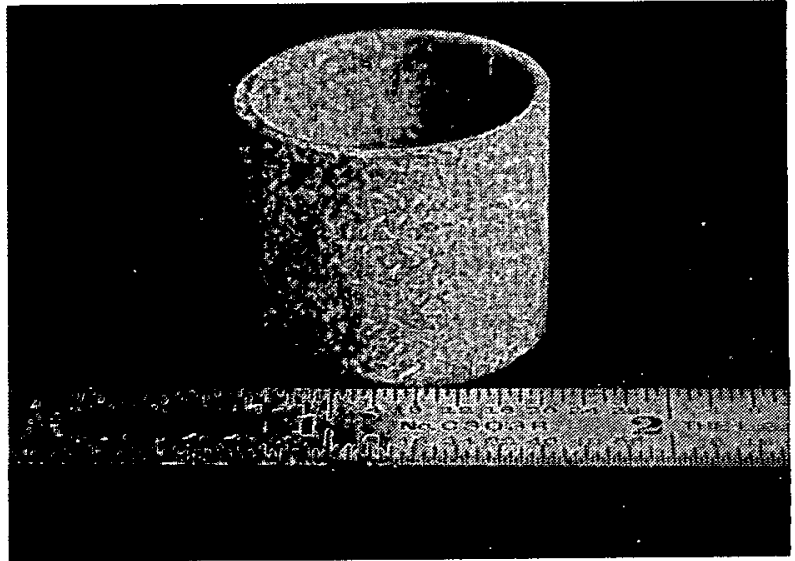

b. After Exposure to Boiling Sodium; After Sodium Removal

Fig. 7. High-fired Recrystallized Alumina Crucible before and after Exposure to Boiling Sodium 
9-12). Samples of HW Corundum were subjected to boiling sodium at high and low power levels. In both cases, the samples retained their shape after sodium removal but a fair amount of spallation had occurred. Figure 13 shows a sample of $\mathrm{HW}$ Corundum after sodium was removed and a sample of HW Corundum that was exposed to sodium at $850^{\circ} \mathrm{C}$ for five hours.

With the exception of HW Corundum, the surviving samples had crushing strengths after exposure of about the same magnitude as those of the unexposed samples. The apparent increase in crushing strengths of some samples after exposure may be related to sample variability or sample anisotropy. Since the orientation of the samples after exposure to sodium relative to the orientation of the unexposed samples was unknown, the exposed and unexposed samples may not have been crushed along the same axis of the brick. The decrease in the crushing strength of HW Corundum may have been caused by the presence of $0.2 \%$ silica in this sample, which was not present in the other surviving high-alumina samples. This effect of silica corresponds to that observed with high-magnesia samples.

Further evidence of the effect of silica is indicated by the failure of Korundal XD, which contained $8.5 \%$ silica. The sample of Korundal XD after exposure to sodium at $850^{\circ} \mathrm{C}$ (Fig. 14) was grey and deformed, and had swelled to such an extent that it appeared to have pressed against the capsule lid. When probed with a spatula, it was found to be similar to metallic sodium in softness. The Korundal XD sample and the HW Ruby sample totally disintegrated when exposed to boiling sodium. The sample of HW Ruby exposed to sodium at $850^{\circ} \mathrm{C}$ for five hours completely lost its shape and was very dark in color (Fig. 15). When probed with a spatual, it also had a softness similar to that of metallic sodium. HW Ruby did not contain silica; however, it contained chromic oxide $\left(\mathrm{Cr}_{2} \mathrm{O}_{3}\right)$, which was not present in the surviving alumina samples.

In agreement with these results, the results of experiments performed at WARD indicate that high-alumina refractories are compatible with high-temperature sodium except for those with a silica content greater than $8 \%$ and for those containing $10 \%$ chromic oxide. ${ }^{7}$

\section{High Zirconia Materials}

Three high-zirconia bricks and two high-zirconia crucibles were tested. Al1 the zirconia bricks were tested by exposure to boiling sodium, two of them ( $\mathrm{ZH} \mathrm{392C} \mathrm{and} \mathrm{ZH} \mathrm{192A}$ ) were exposed for about one hour, and the third, a sintered zirconia fire brick, was exposed for about 1-1/2 hours. One highfired zirconia crucible was exposed to boiling sodium for about $1-1 / 2$ hours and the other was exposed to static sodium at $850^{\circ} \mathrm{C}$ for about five hours.

$\mathrm{ZH} 392 \mathrm{C}$ and $\mathrm{ZH} 192 \mathrm{~A}$ are composed of the same chemical constituents; they differ only in that $\mathrm{ZH} 392 \mathrm{C}$ is composed of medium-grain material, whereas $\mathrm{ZH} 192 \mathrm{~A}$ is composed of coarse-grain material. Neither material withstood the

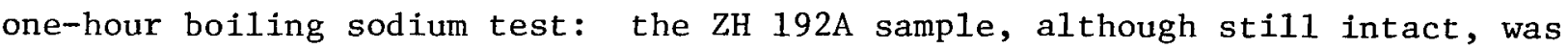
considerably deformed (Fig. 16); whereas the $\mathrm{ZH} 392 \mathrm{C}$ sample was totally disintegrated, and its residue was not recovered from the sodium. The behavior of the sintered zirconia fire brick, which was boiled in sodium for about 1-1/2 hours, was similar to that of $\mathrm{ZH} 392 \mathrm{C}$, and its residue was also not recovered. These results differ from those of experiments performed at WARD where both zirconia bricks tested ( $\mathrm{ZH} \mathrm{392C} \mathrm{and} \mathrm{ZH}$ 192A) survived intact with some discoloration and surface powdering after sodium removal. 


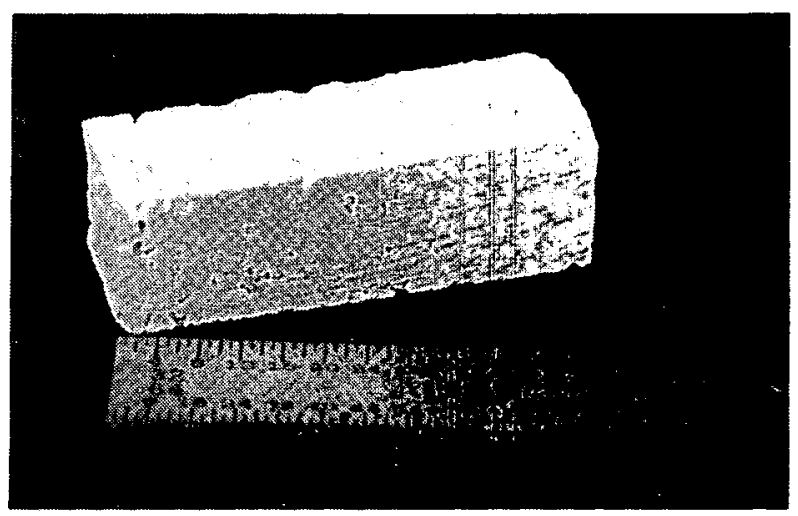

a. Before Sodium Exposure

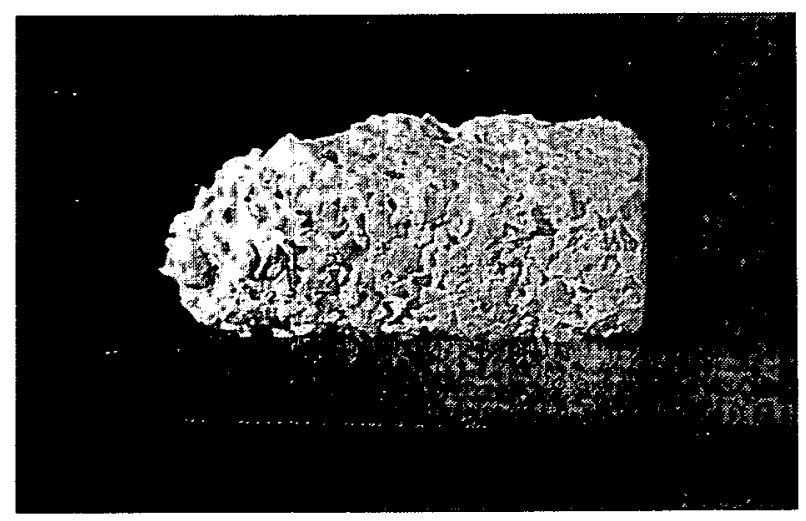

b. After Exposure to Boiling Sodium; After Sodium Removal

Fig. 8. Alumina Brick Sample before and after Exposure to Boiling Sodium

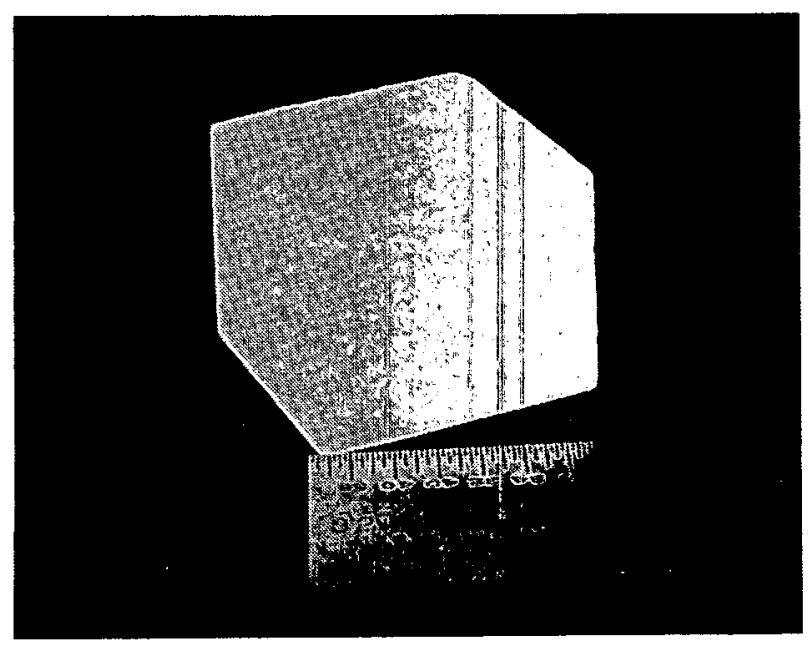

a. Before Sodium Exposure

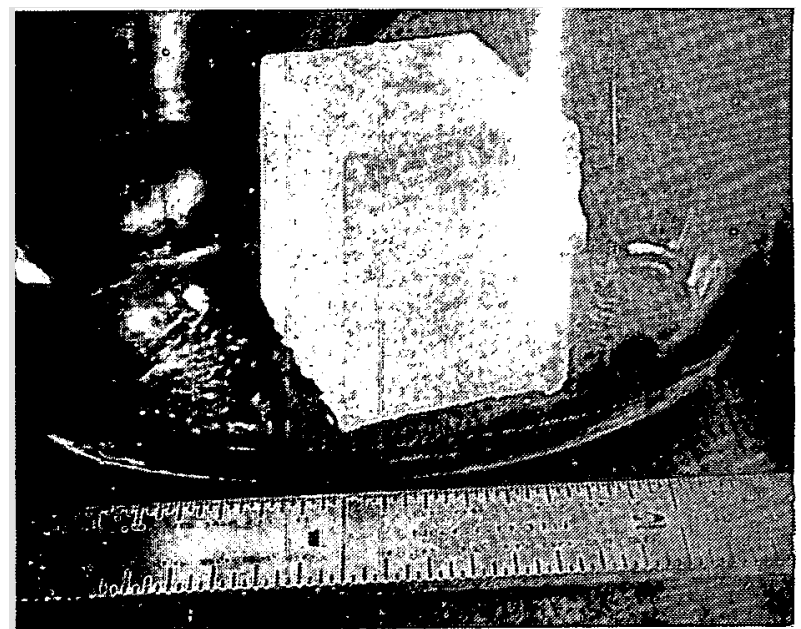

b. After Exposure to Boiling Sodium; Before Sodium Removal

Fig. 9. High Alumina Material, A-414, before and after Exposure to Boiling Sodium 


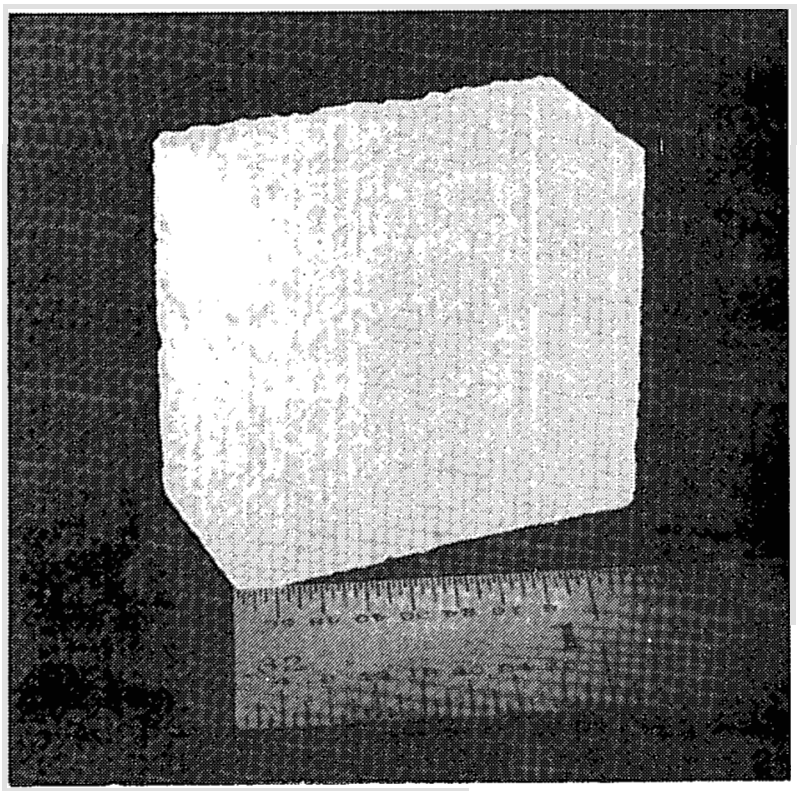

a. Before Sodium Exposure

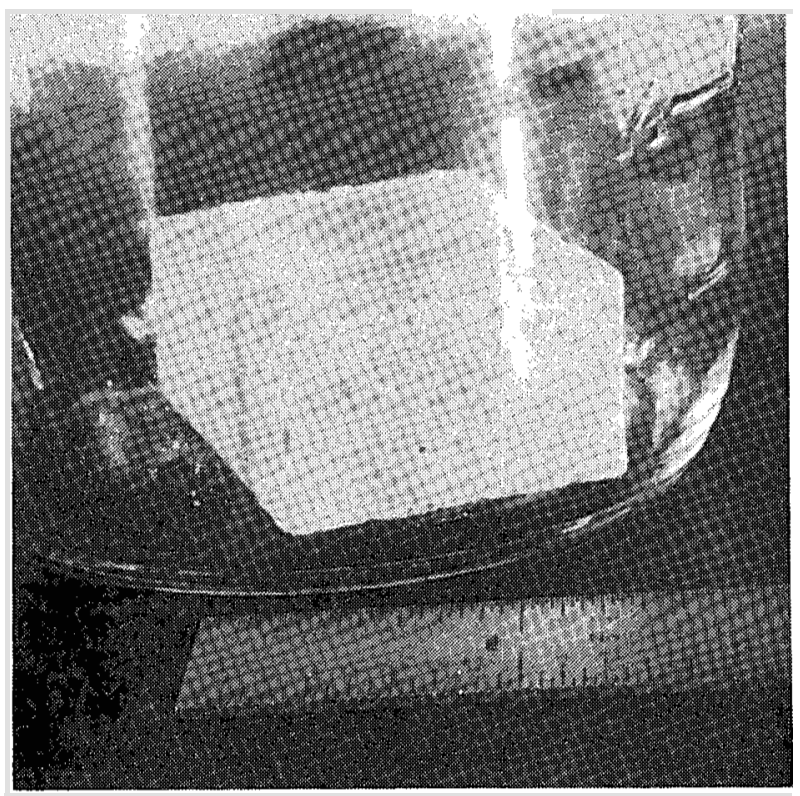

b. After Exposure to Boiling Sodium; Before Sodium Removal

Fig. 10. High Alumina Material, AH 199B, before and after Exposure to Boiling Sodium

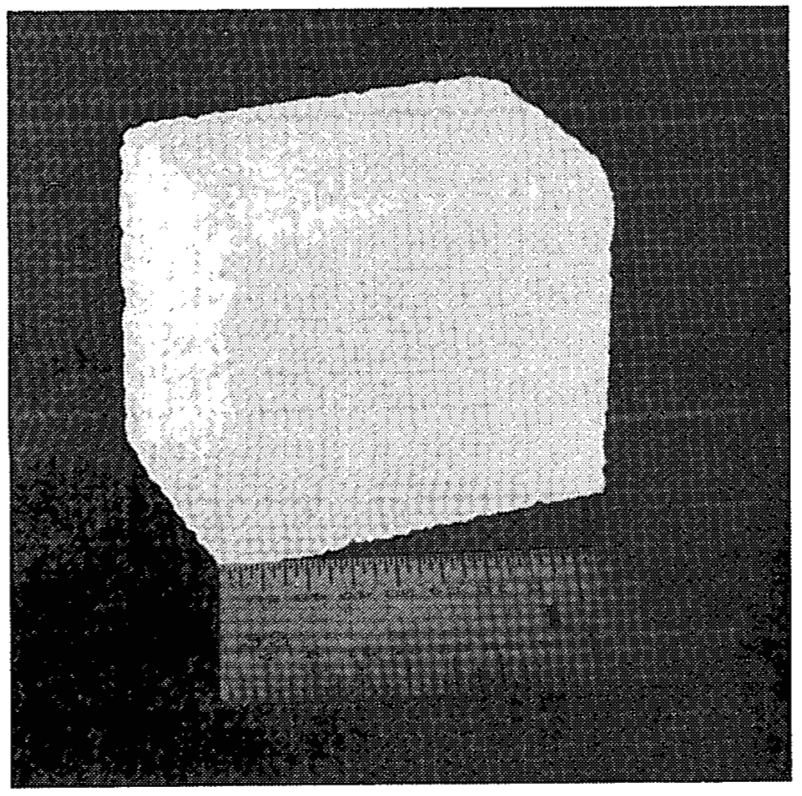

a. Before Sodium Exposure

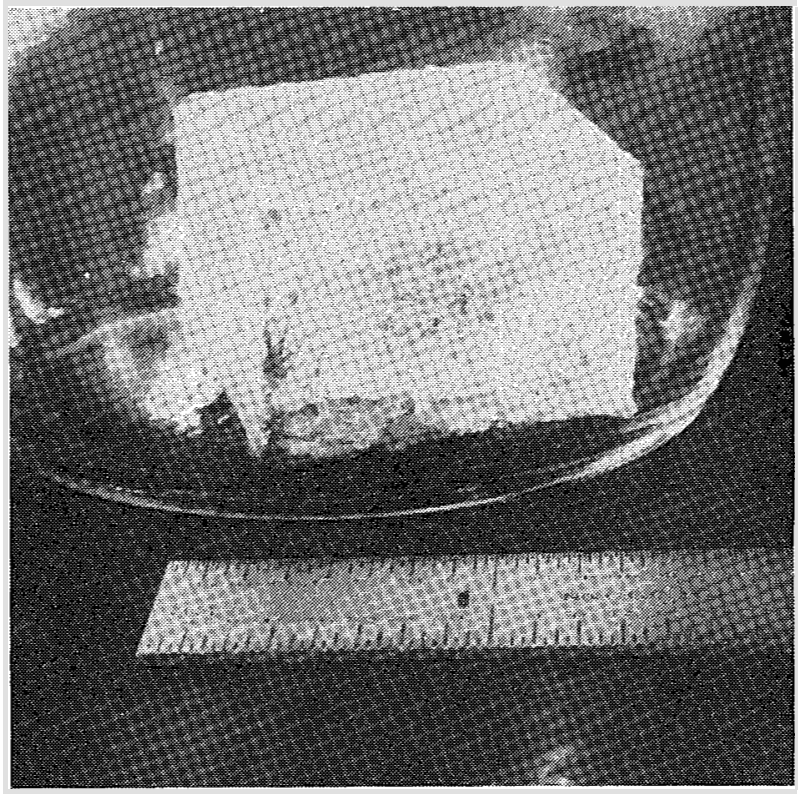

b. After Exposure to Boiling Sodium; Before Sodium Removal

Fig. 11. High Alumina Material, AN 199B, before and after Exposure to Boiling Sodium 


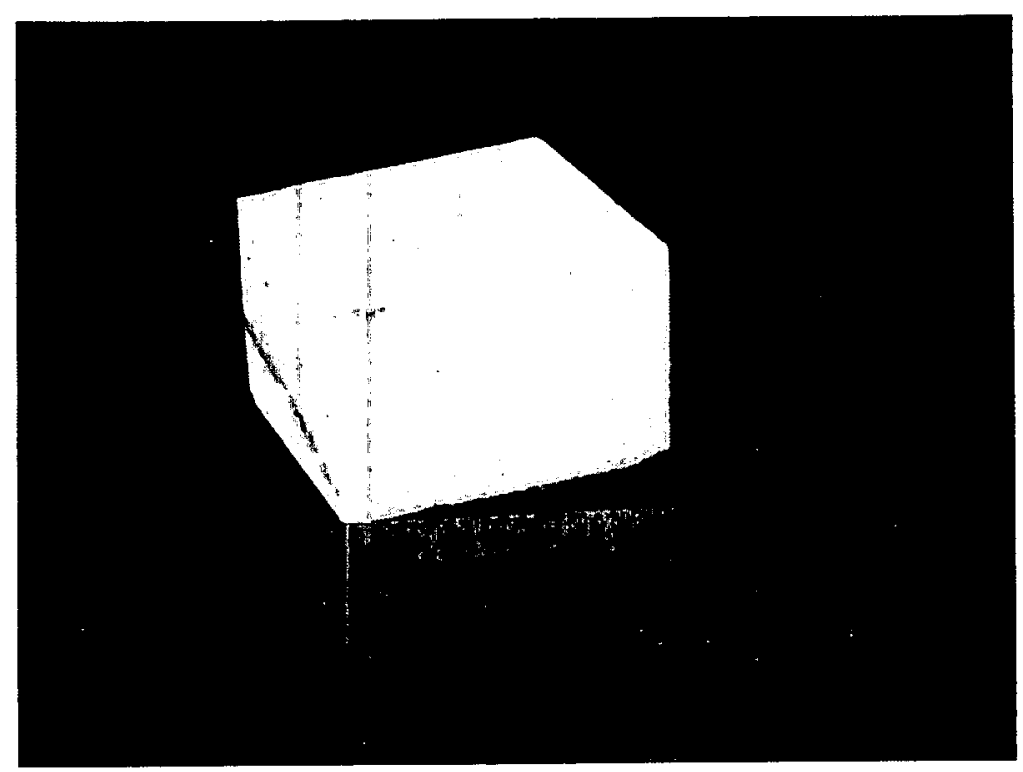

a. Before Sodium Exposure

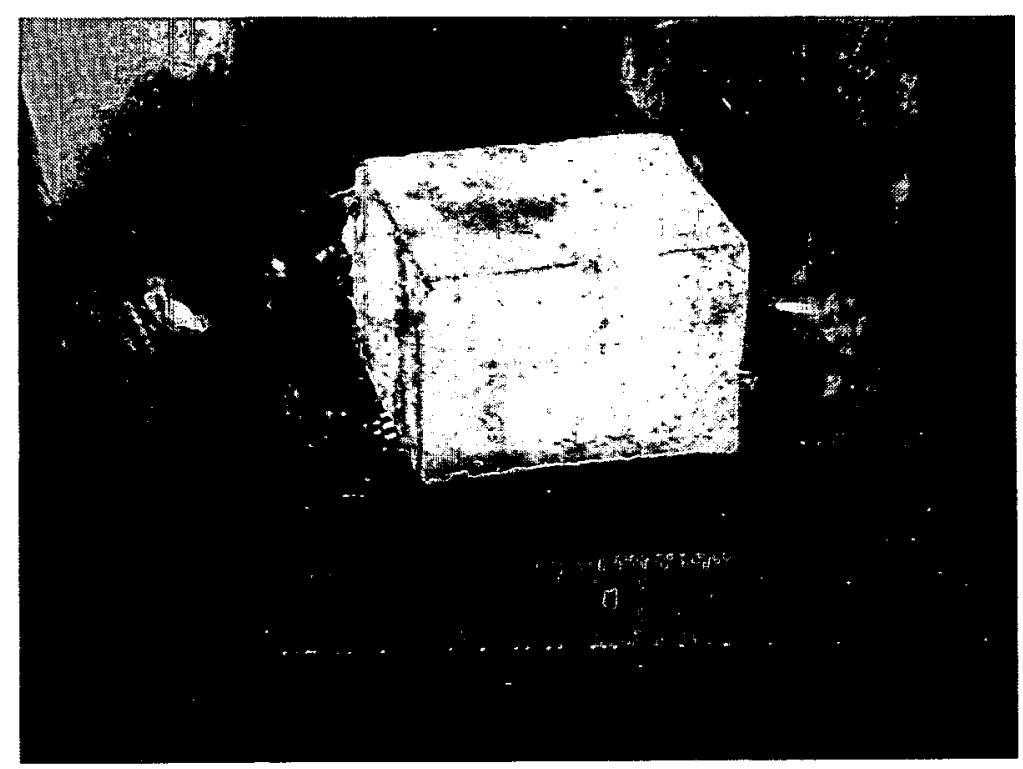

b. After Exposure to Boiling Sodium; Before Sodium Removal

Fig. 12. High Alumina Material, SR-504C, before and after Exposure to Boiling Sodium 


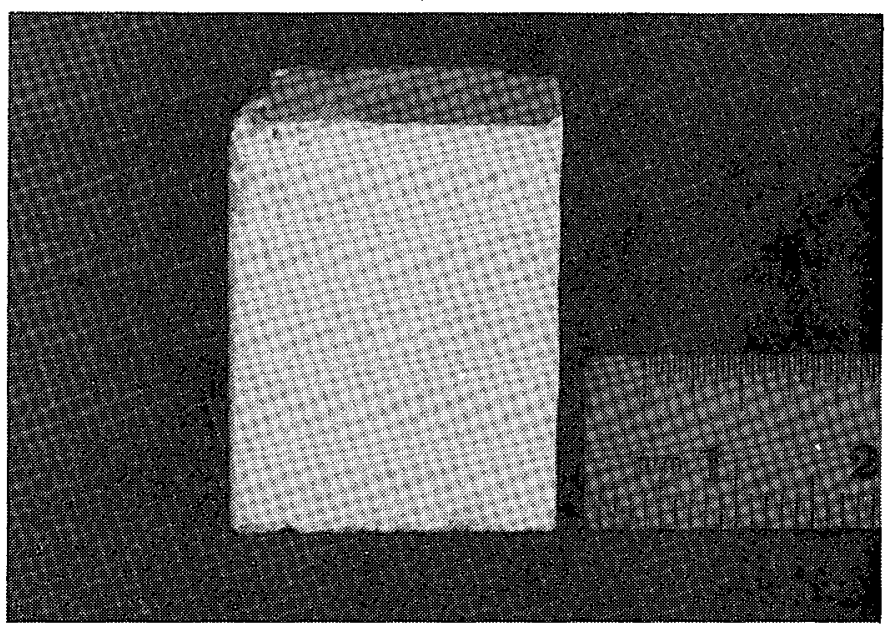

a. Before Sodium Exposure

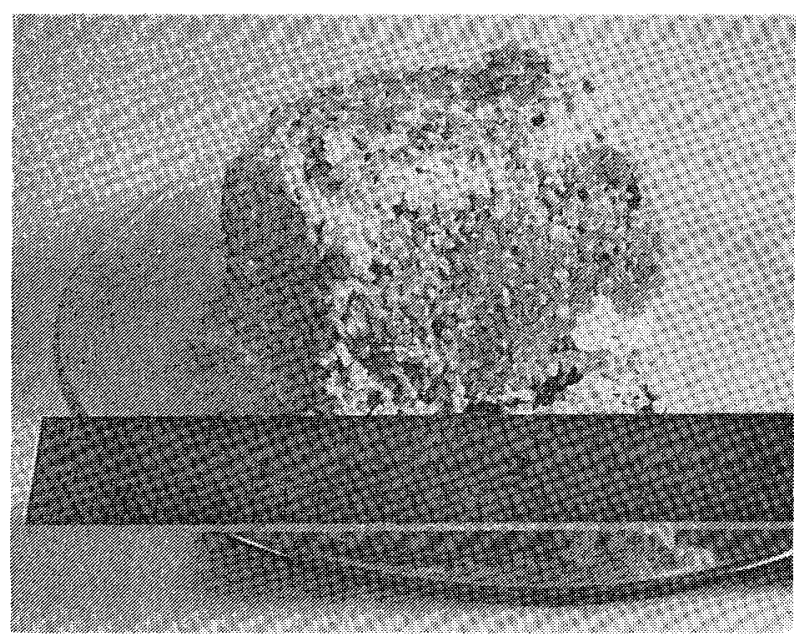

b. After Exposure to Boiling Sodium; After Sodium Removal

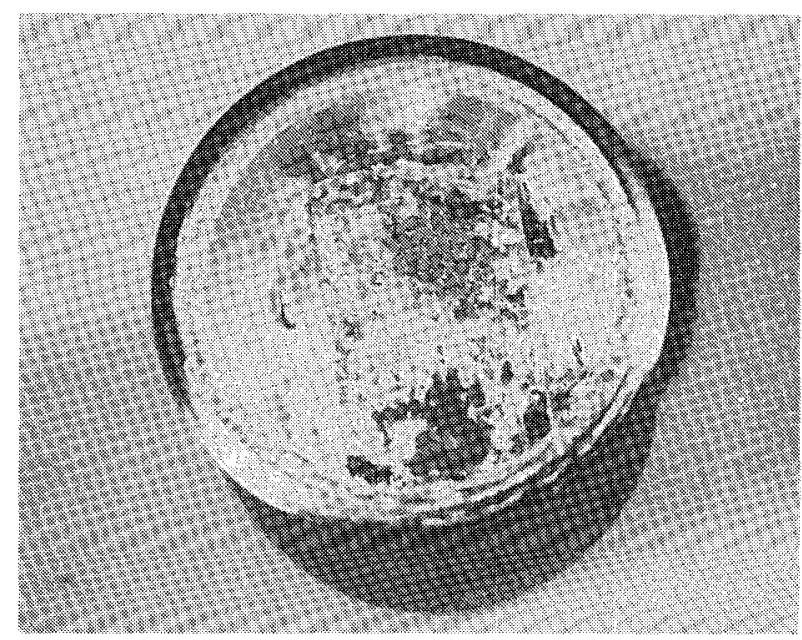

C. After Exposure to Static Sodium at $850^{\circ} \mathrm{C}$

Fig. 13. High Alumina Material, HW Corundum, before and after Sodium Exposure 


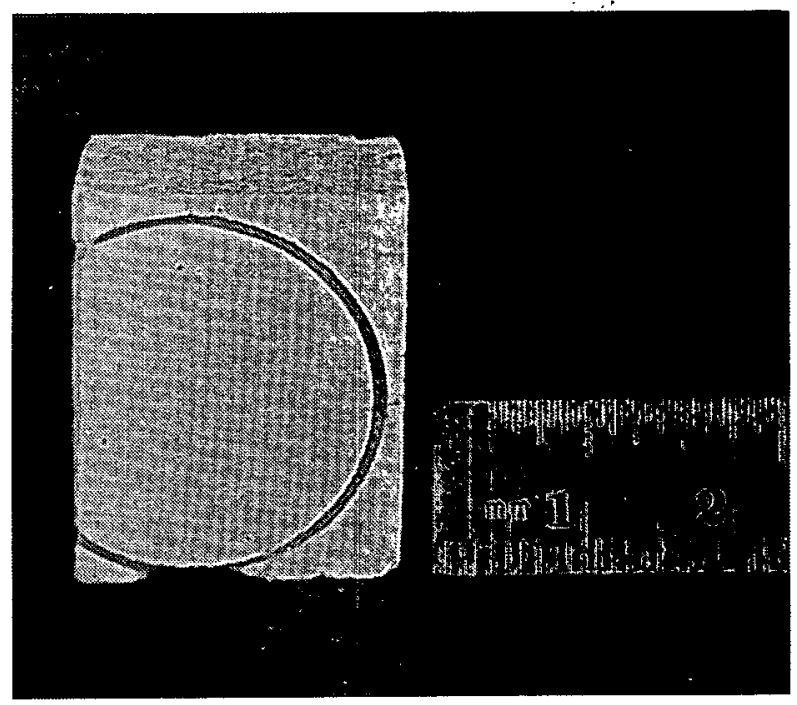

a. Before Sodium Exposure

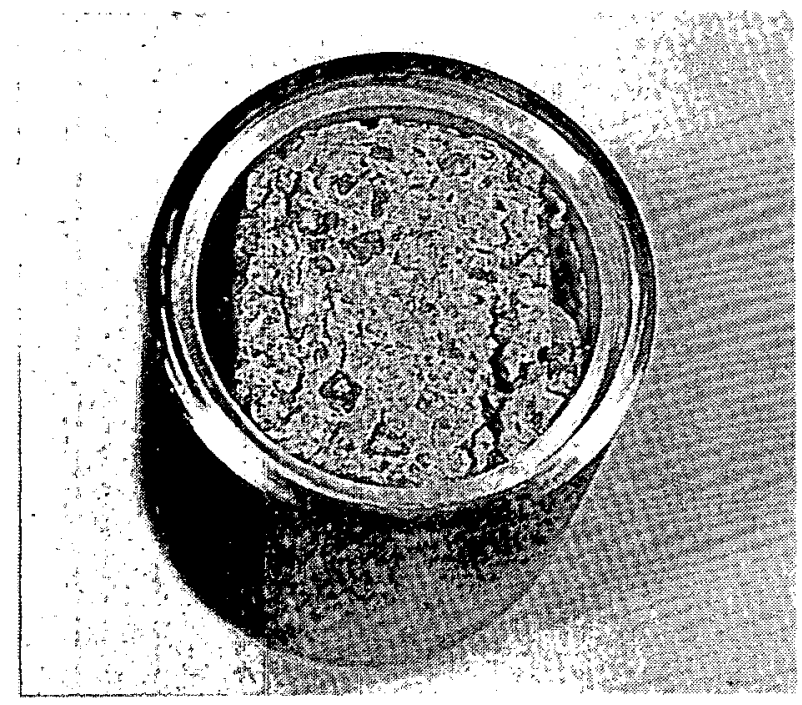

b. After Exposure to Static Sodium

Fig. 14. High Alumina Material, Korundal XD, before and after Exposure to Static Sodium at $850^{\circ} \mathrm{C}$

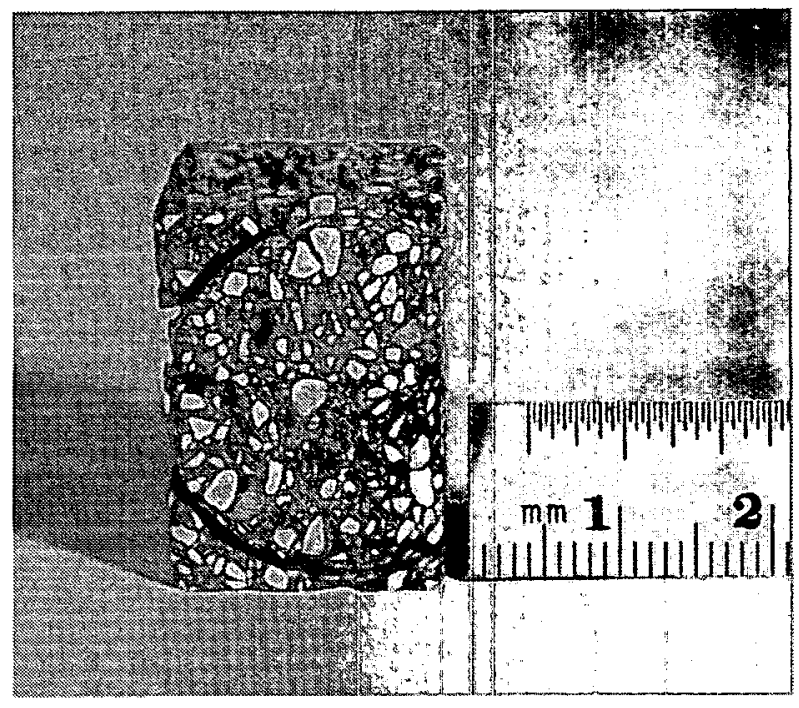

a. Before Sodium Exposure

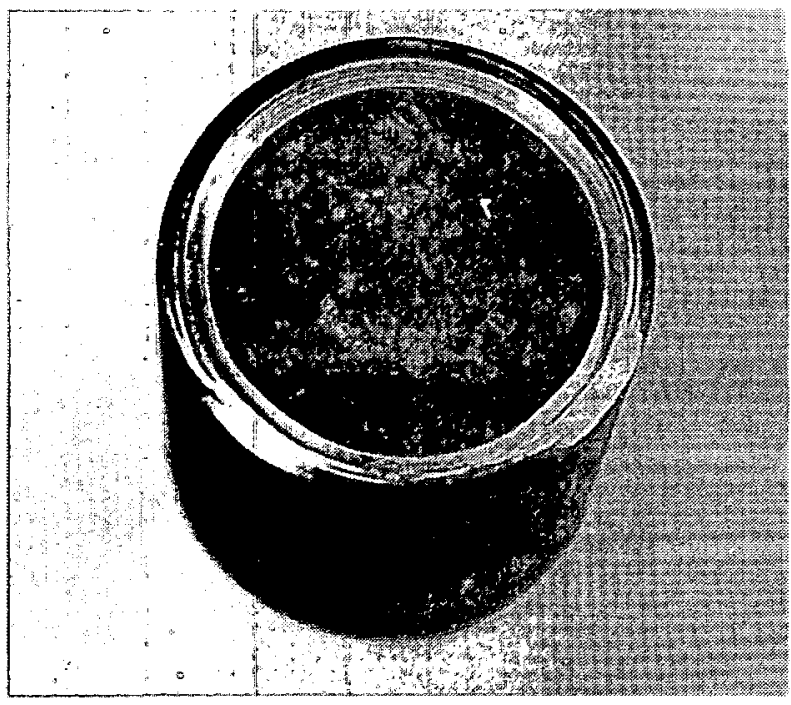

b. After Exposure to Static Sodium

Fig. 15. High Alumina Material with $10 \% \mathrm{Cr}_{2} \mathrm{O}_{3}, \mathrm{HW}$ Ruby, before and after Exposure to Static Sodium at $850^{\circ} \mathrm{C}$ 


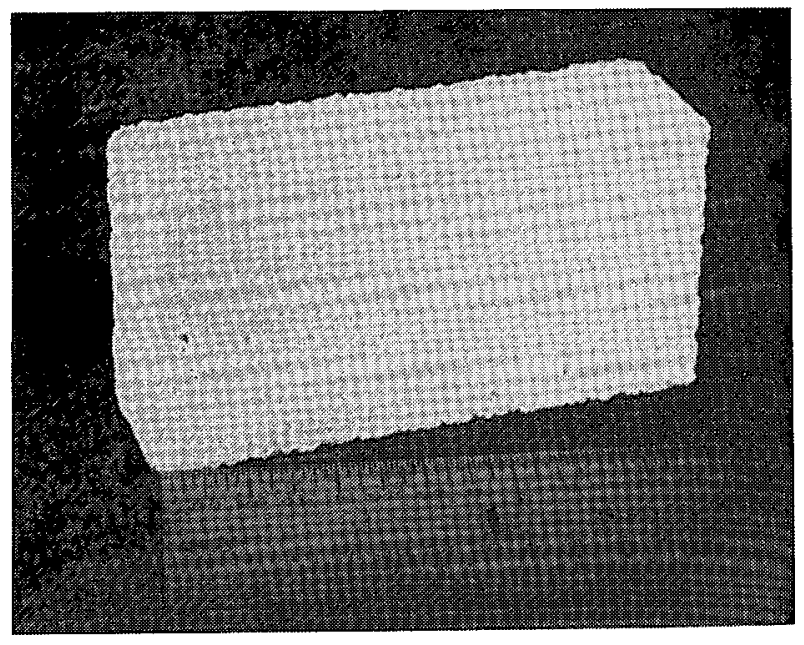

a. Before Sodium Exposure

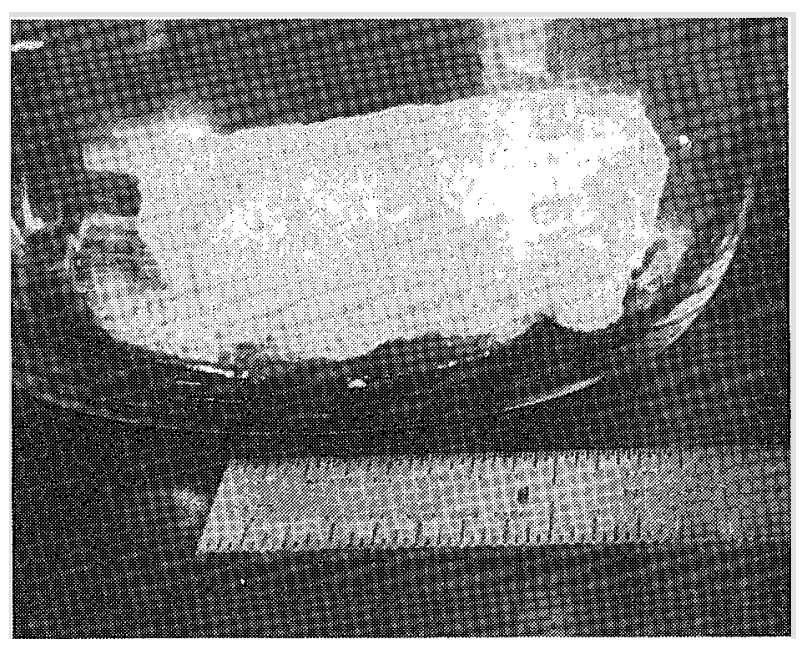

b. After Exposure to Boiling Sodium; Before Sodium Removal

Fig. 16. Zirconia Brick Sample, ZH 192A, before and after Exposure to Boiling Sodium

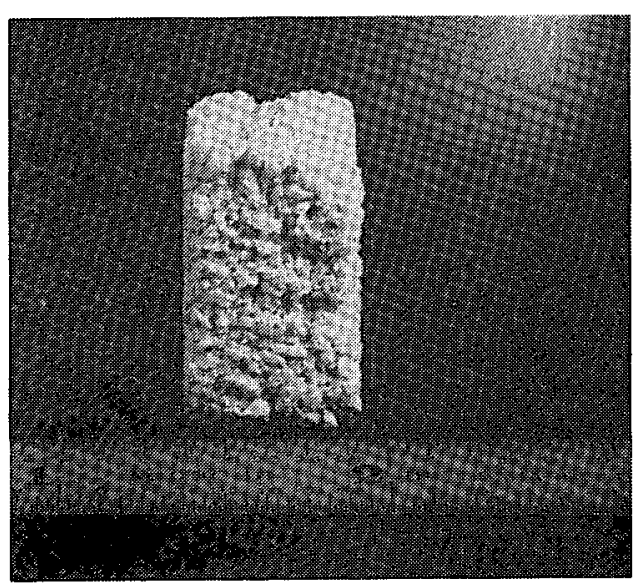

a. Before Sodium Exposure

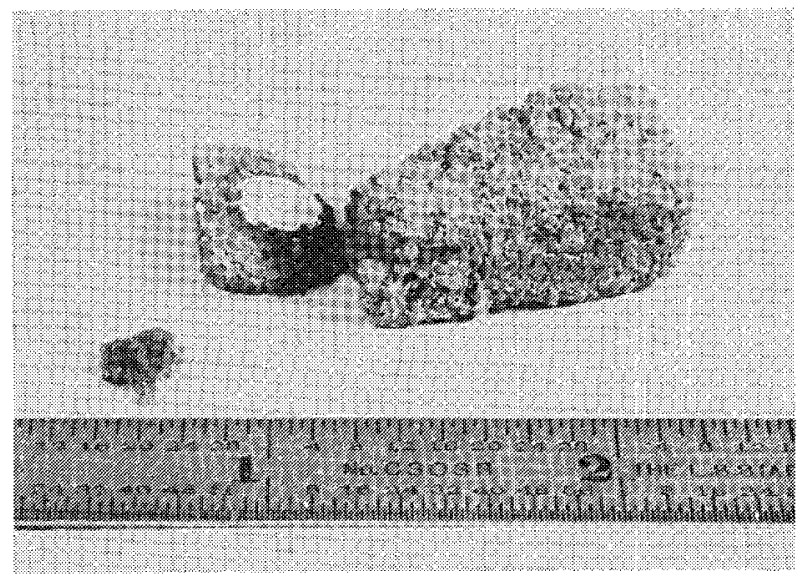

b. After Exposure to Boiling Sodium; After Sodium Removal

Fig. 17. High-fired Zirconia Crucible Piece before and after Exposure to Boiling Sodium 
In contrast with the failure of the zirconia bricks, the crucible of high-fired zirconia exposed to boiling sodium survived, with only a smal1 crack developing. Sodium penetrated the crack, but after sodium removal, the crucible weight loss was only $0.2 \%$. After exposure to static sodium at $850^{\circ} \mathrm{C}$ for five hours, the high-fired crucible of Norton Mix Z-302 zirconia appeared to be unreacted and was thoroughly wetted with clean sodium. Figures 17 and 18 show the crucibles before and after exposure. Crushing tests were not performed on the crucibles. Although the crucible of Norton Mix Z-302 had the same chemical composition as the samples of $\mathrm{ZH} 392 \mathrm{C}$ and $\mathrm{ZH} 192 \mathrm{~A}$, it differed from them by being a fine-grained high-fired crucible, whereas they were dense, fused, lime-stabilized bricks and were of coarser grain. Thus, the difference in compatibility between the bricks and crucibles with hightemperature sodium is likely due to differences in fabrication.

\section{Mixed Ceramic Oxides}

The refractory materials containing large percentages of alumina and silica (Duro Fireclay Acid Brick and Varnon BF Hard Burned Super Duty Fireclay experienced significant reaction in both types of experiments performed at ANL and in the experiments performed at WARD.' The samples exposed to static sodium at $850^{\circ} \mathrm{C}$ for five hours are shown before and after exposure in Figs. 19 and 20. After exposure, the sample of Duro Fireclay was dark in color, and was hard but crumbly. Varnon BF was dark, but not hard. It swelled to such an extent that it pressed against the top of the capsule during the test, as evidenced by the attachment of some of the sample to the lid of the capsule (see photo at lower right in Fig. 20). In the boiling sodium experiment, the samples experienced such a gross structural breakdown that they no longer resembled the initial samples; most of the material was present as a slurry with the sodium. The complete failure of these samples is attributed to their large silica content; they contained more than $50 \%$ silica.

Samples of $X-317, C-104$, and RFG were exposed to boiling sodium for one hour. The magnesia-alumina material, $X-317$, survived intact (Fig. 21). However, a comparison in crushing strength could not be made because the unexposed sample was considered to be nonrepresentative, as is evident from Fig. 22. Although the chemical compositions of C-104 and RFG are almost identical, C-104 survived intact (Fig. 23) and retained about $76 \%$ of its crushing strength, whereas RFG was invaded by sodium, which created a coarse structure in the sample. The exposed RFG sample, which is shown in Fig. 24, retained only about $34 \%$ of its crushing strength. In experiments at WARD, X-317, C-104, and RFG remained intact after sodium removal; the corners and edges of $R F G$ had fractured, whereas $\mathrm{X}-317$ and $\mathrm{C}-104$ were not visibly changed.

Zirconia-based mixed ceramic oxides UNICOR I and ZS 1300 were exposed to boiling sodium for about one hour. UNICOR I, an alumina-zirconia refractory brick with a large fraction of silica, partially disintegrated and broke into two pieces, each of which was partially disintegrated (Fig. 25). One of these pieces was crushed to determine its residual strength. Only $18 \%$ of the unexposed sample's crushing strength was retained, which further indicated the structural degradation of the sample. The zirconia-silica sample, ZS 1300, showed considerable disintegration after exposure to boiling sodium (Fig. 26). Samples of UNICOR I and ZS 1300 also failed to withstand exposure to boiling sodium in experiments performed at WARD. ${ }^{7}$ The failure of UNICOR I and ZS 1300 is further evidence that refractory materials with high silica content cannot withstand exposure to boiling sodium. 


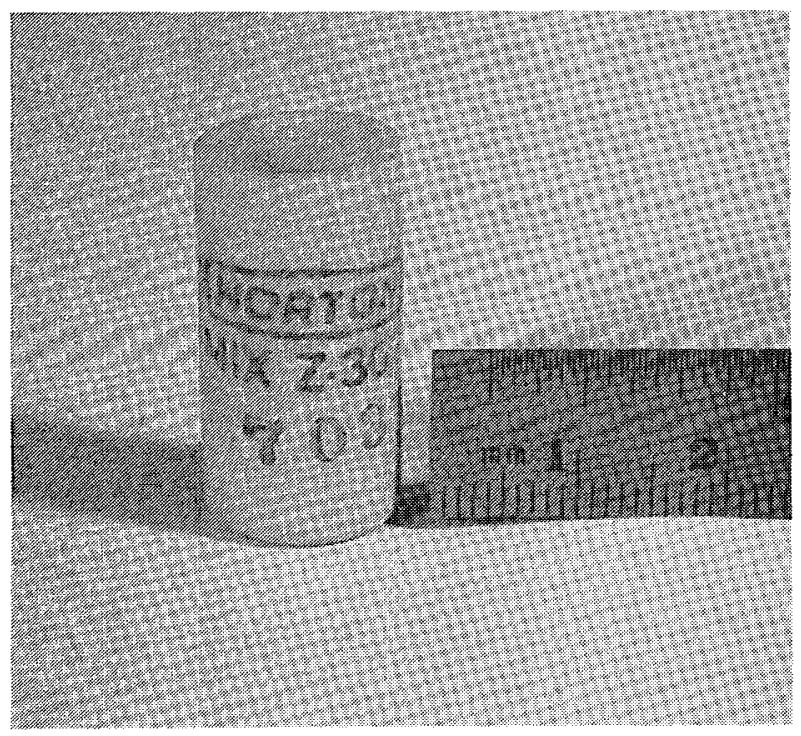

a. Before Sodium Exposure

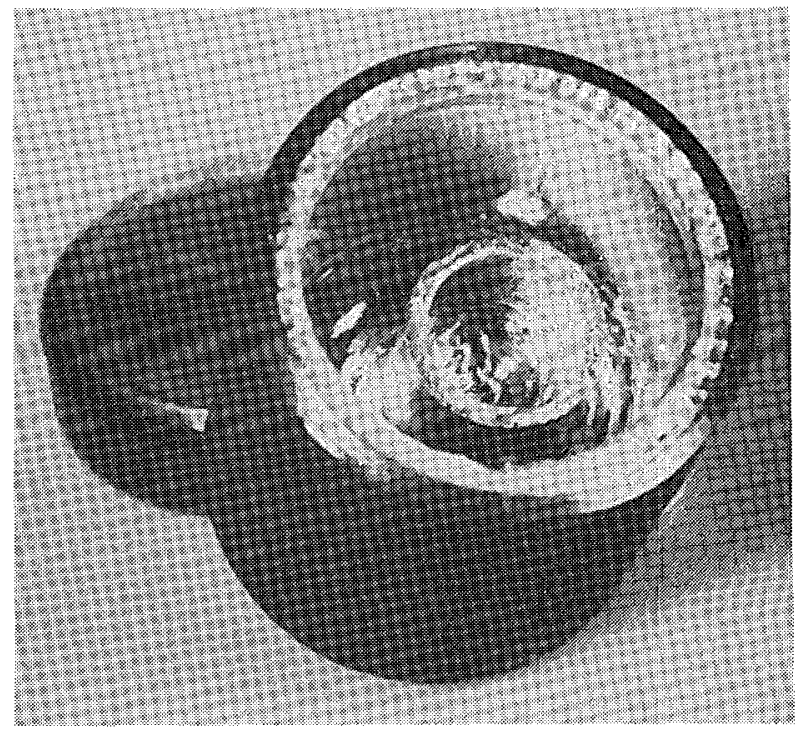

b. After Exposure to Static Sodium

Fig. 18. High-fired Zirconia Crucible, Norton Mix Z-302, before and after Exposure to Static Sodium at $850^{\circ} \mathrm{C}$

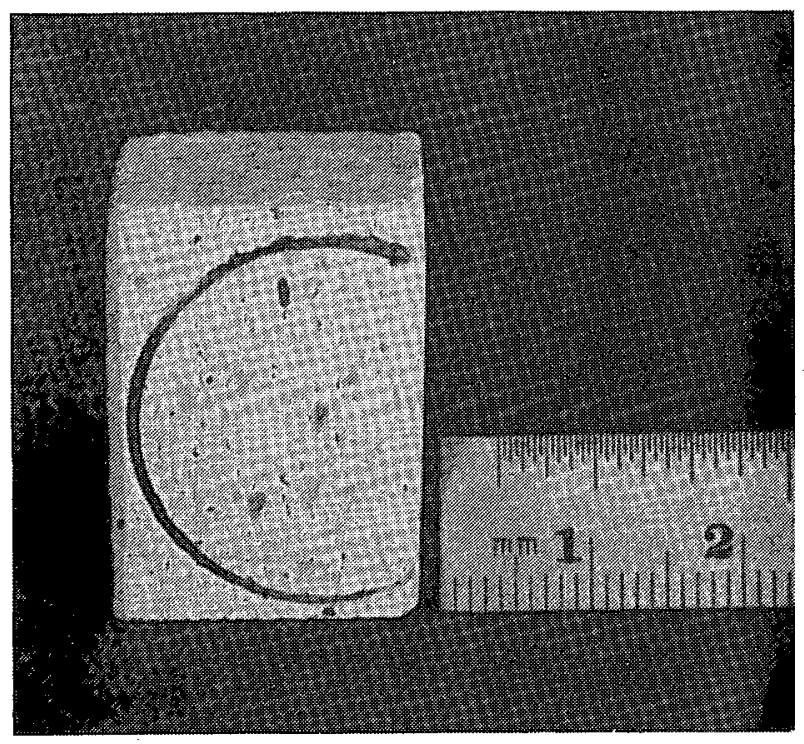

a. Before Sodium Exposure

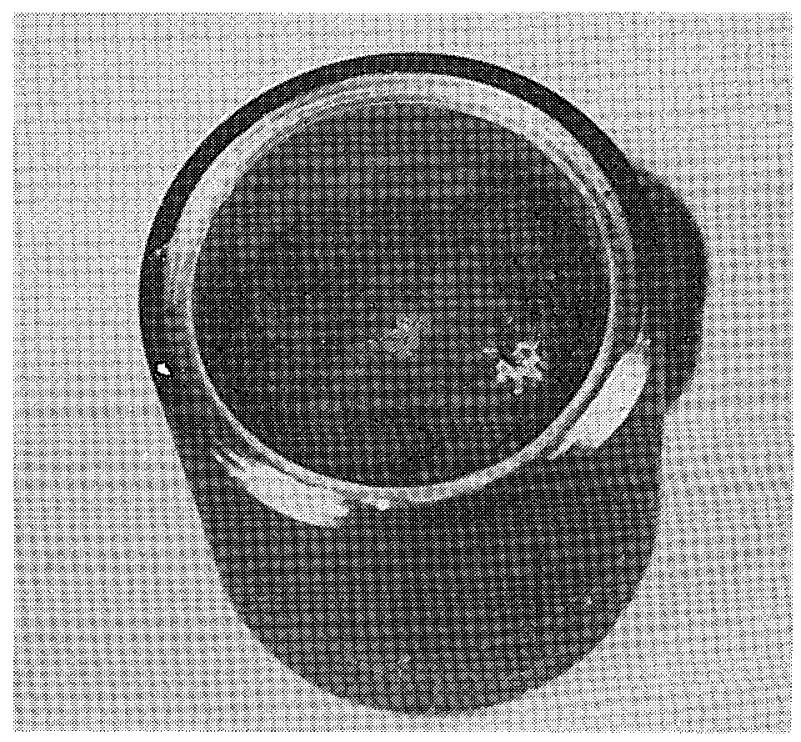

b. After Exposure to Static Sodium

Eig. 19. Sample of Duro Fireclay Acid Brick before and after Exposure to Static Sodium at $850^{\circ} \mathrm{C}$ 


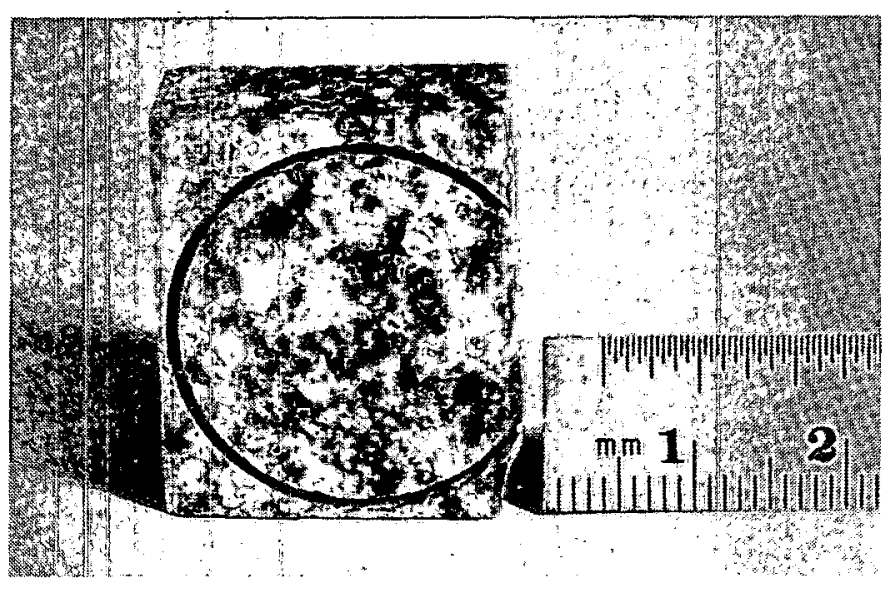

a. Before Sodium Exposure
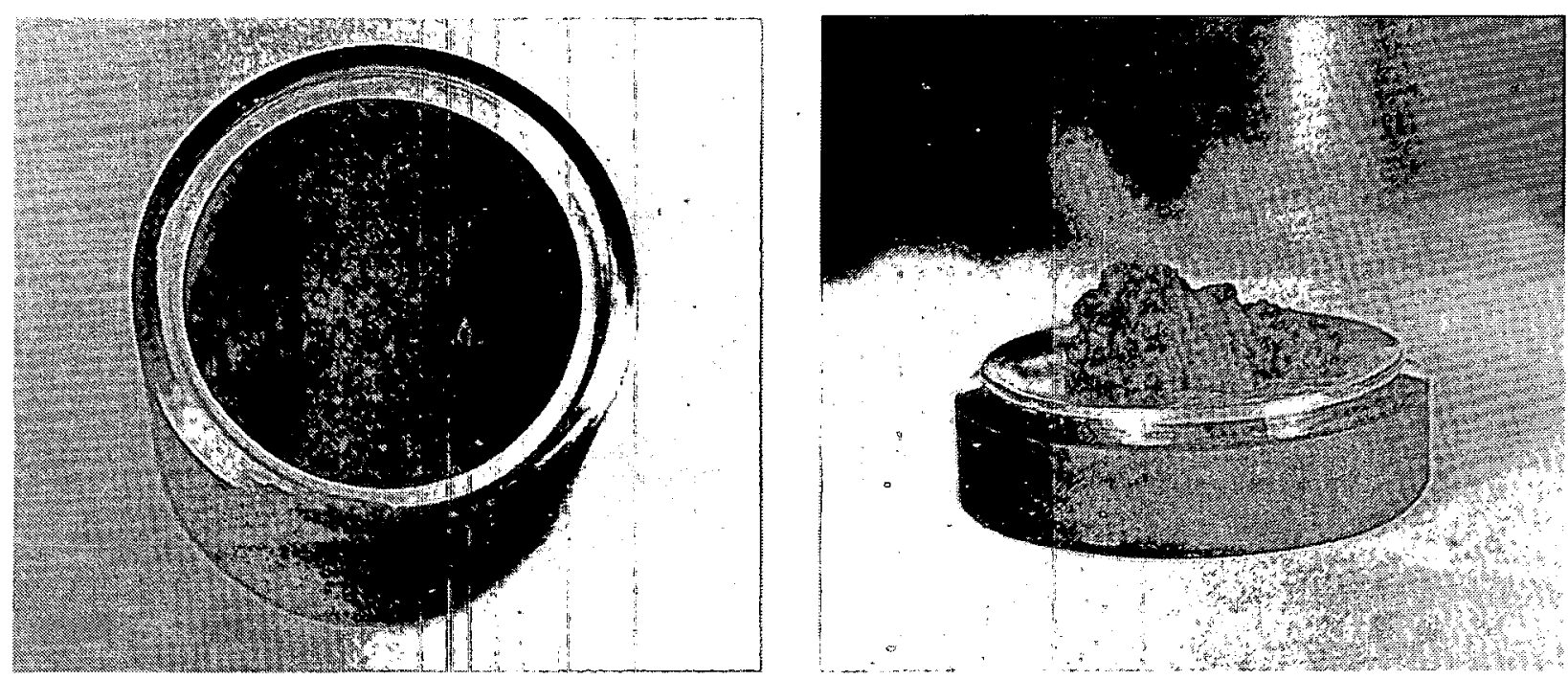

b. After Exposure to Static Sodium (two views)

Fig. 20. Sample of Vamon BF Hard Burned Super Duty Fireclay before and after Exposure to Static Sodium at $850^{\circ} \mathrm{C}$ 


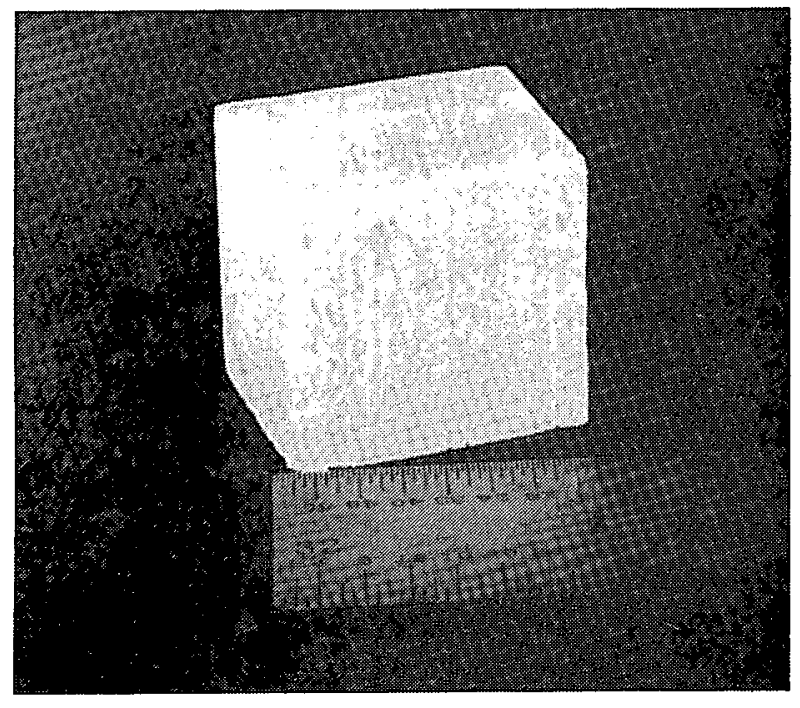

a. Before Sodium Exposure

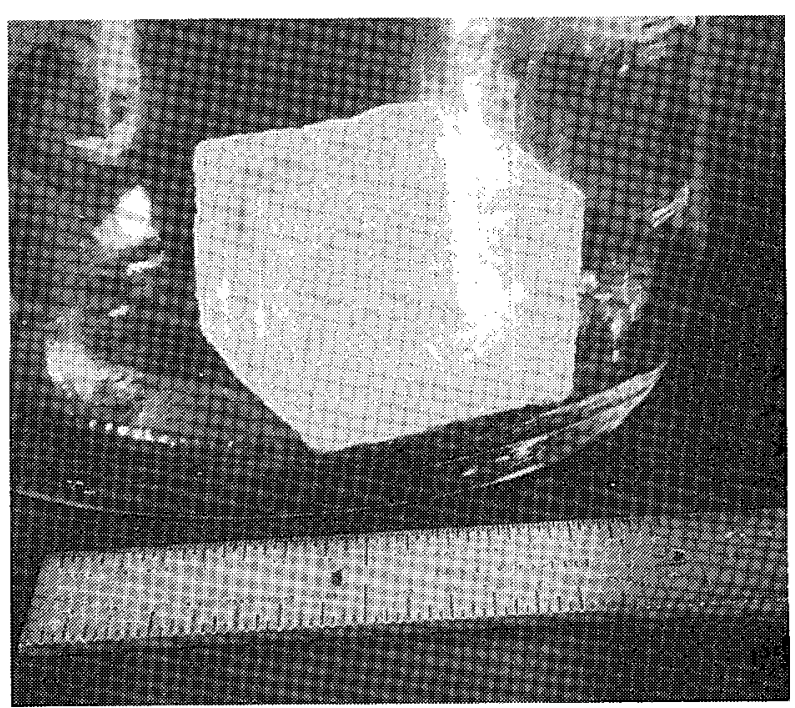

b. After Exposure to Boiling Sodium; Before Sodium Removal

Fig. 21. Magnesia-Alumina Based Materia1, X-317, before and after Exposure to Boiling Sodium

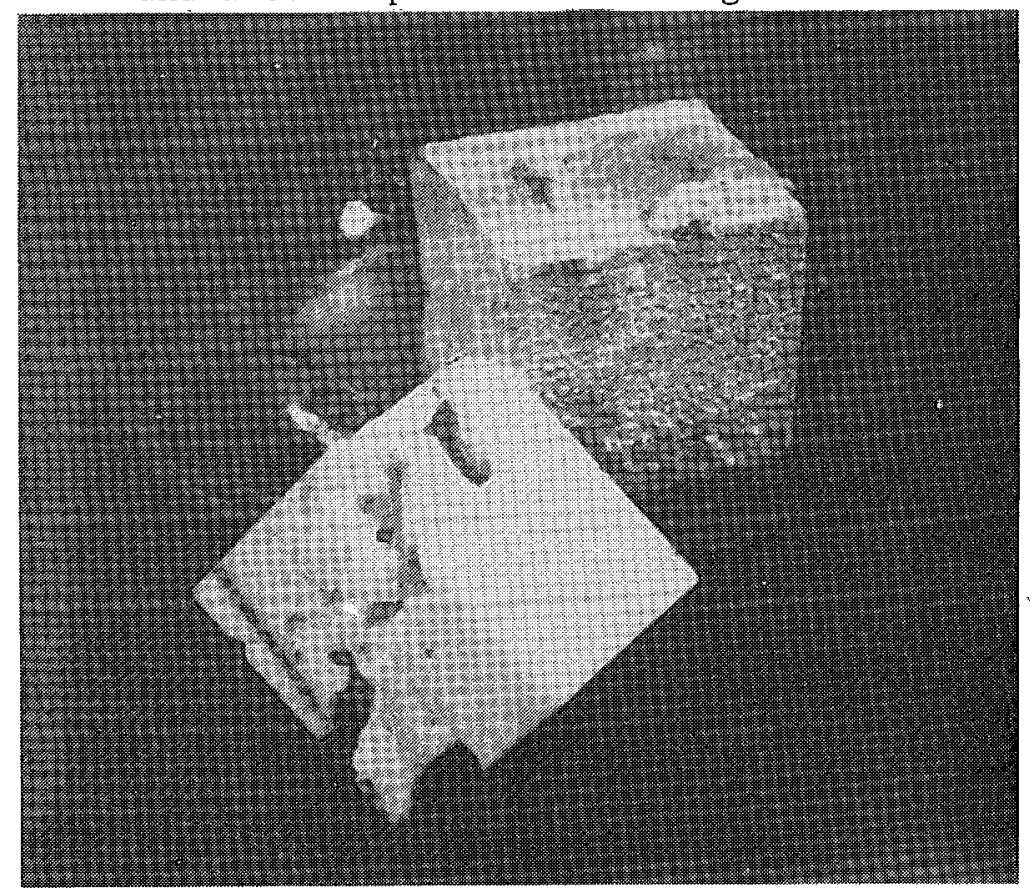

Fig. 22. Samples of X-317: Unexposed Sample (lower left) and Sample after Exposure to Boiling Sodium (upper right) 


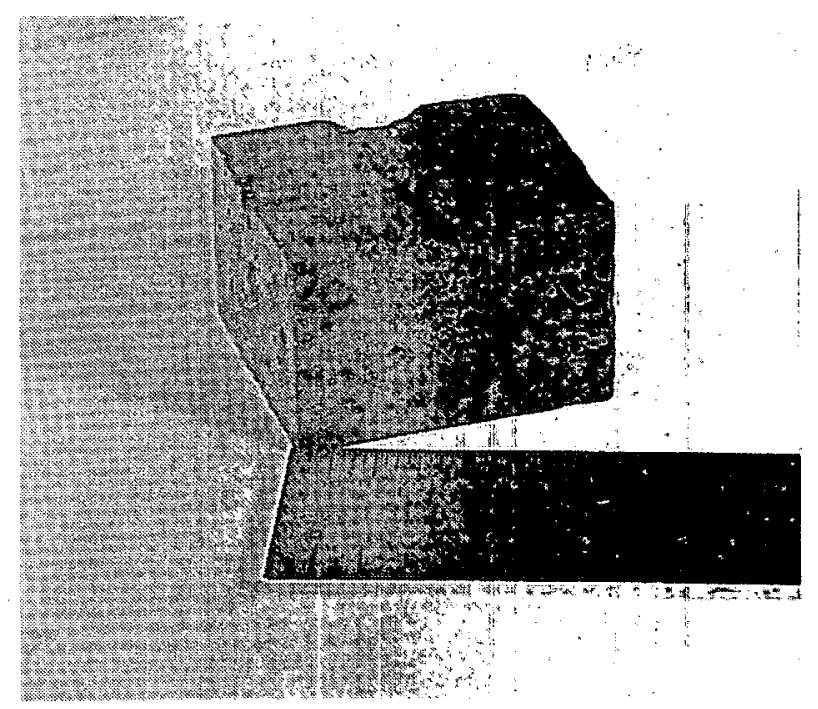

a. Before Sodium Exposure

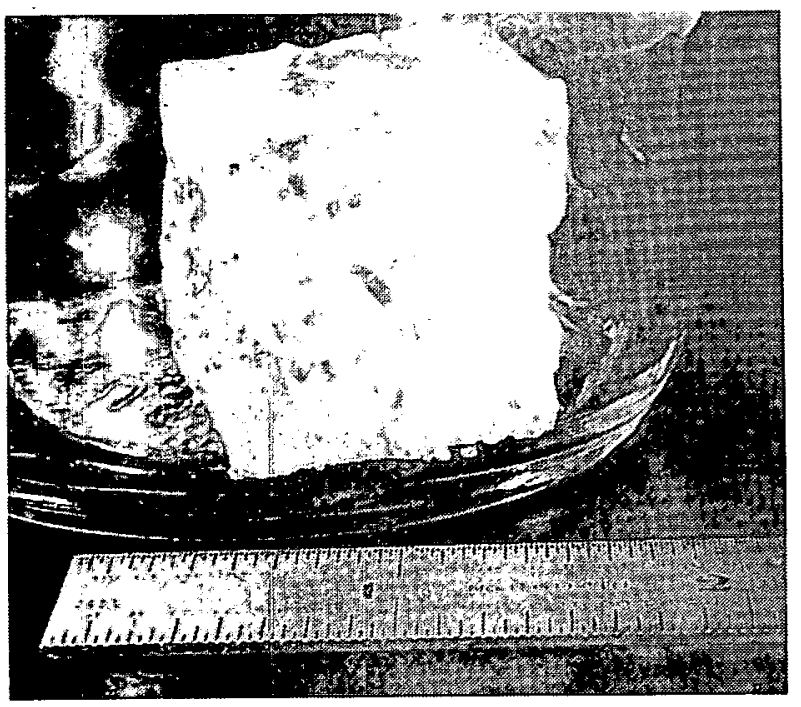

b. After Exposure to Boiling Sodium; Before Sodium Removal

Fig. 23. Magnesia Based Mixed Refractory, C-104, before and after Exposure to Boiling Sodium

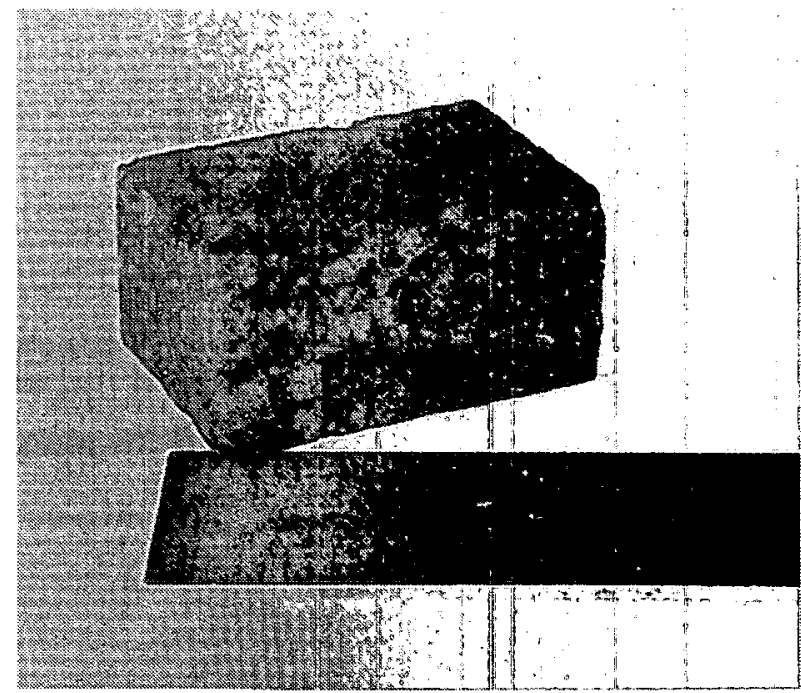

a. Before Sodium Exposure

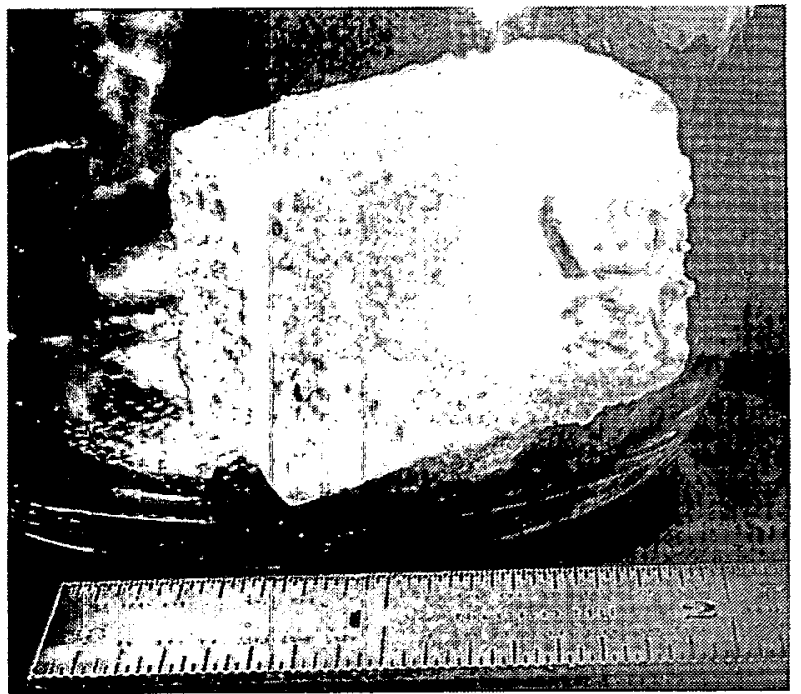

b. After Exposure to Boiling Sodium

Fig. 24. Magnesia Based Mixed Refractory, RFG, before and after Exposure to Boiling Sodium 


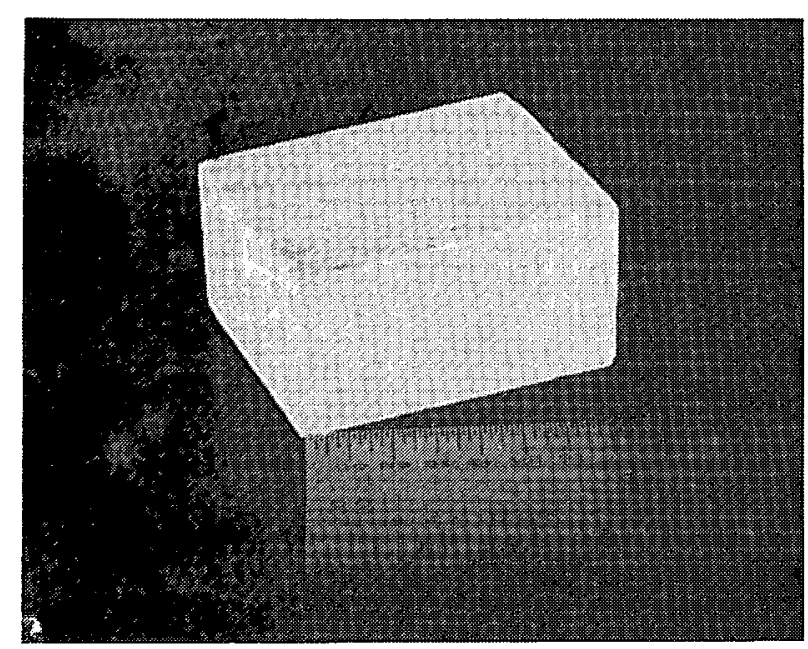

a. Before Sodium Exposure

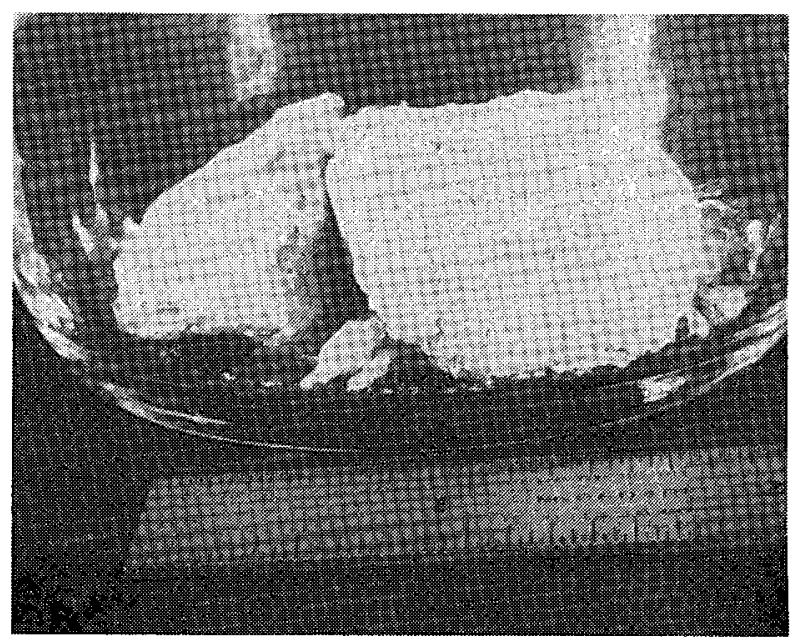

b. After Exposure to Boiling Sodium; Before Sodium Removal

Fig. 25. Alumina-Zirconia Mixed Refractory, UNICOR I, before and after Exposure to Boiling Sodium

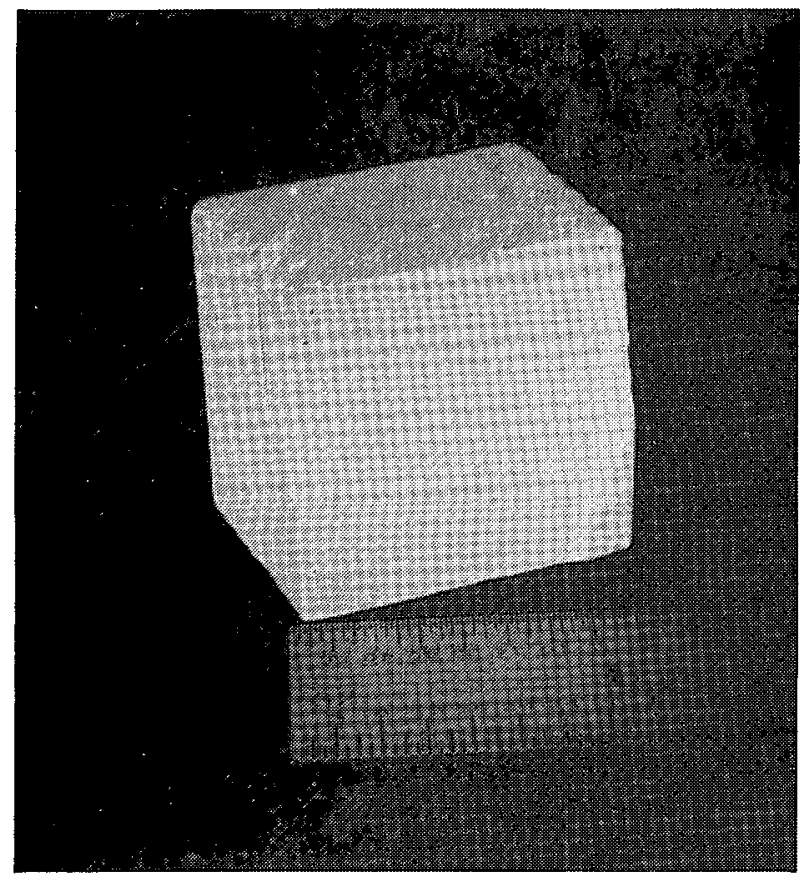

a. Before Sodium Exposure

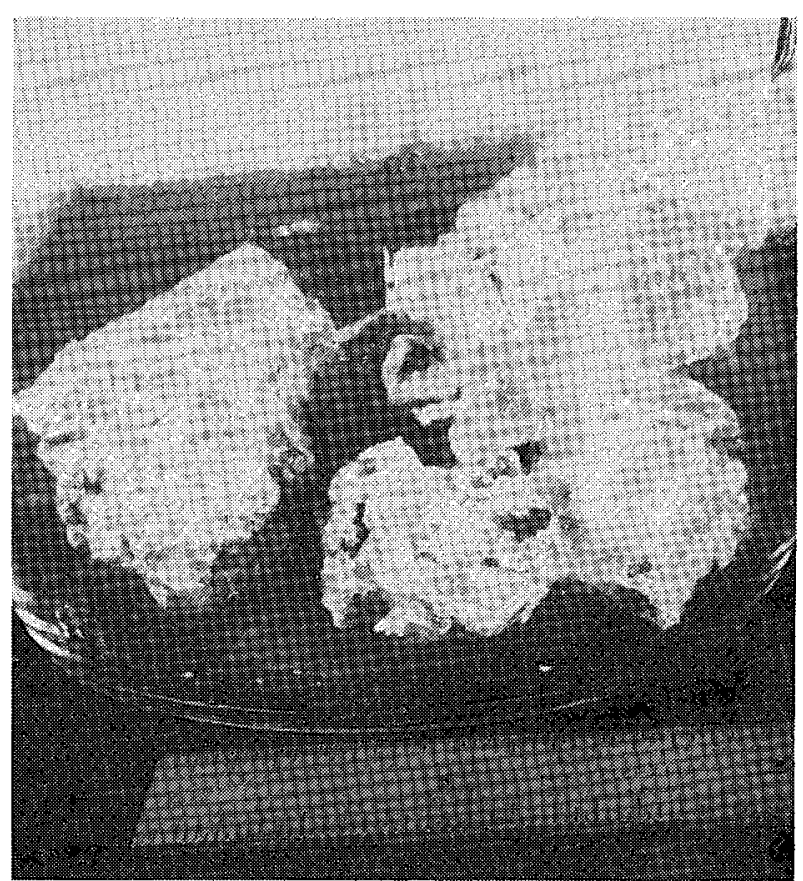

b. After Exposure to Boiling Sodium

Fig. 26. Zirconia-Silica Mixed Refractory, ZS 1300, before and after Exposure to Boiling Sodium 


\section{E. Graphite}

A high-density graphite brick was exposed to boiling sodium for about one hour, and various grades of graphite and a sample of a vitreous carbon rod were exposed to sodium at $850^{\circ} \mathrm{C}$ for five hours. The graphite brick exposed to boiling sodium survived intact, but some surface powdering was evident after sodium removal (Fig. 27). Its weight loss was $1 \%$. After several weeks of exposure to air, the graphite split along parallel planes. Alkali metal atoms are known to diffuse into graphite, positioning themselves between the hexagonal layer planes. ${ }^{10}$ This causes a change in density and can cause internal strains. Subsequent1y, the material splits in response to these strains. Figures 28 through 31 show samples of graphite and vitreous carbon before and after the five-hour exposure to static sodium at $850^{\circ} \mathrm{C}$. None of the samples appeared to undergo interaction, and all were wetted with clean sodium following exposure. There was no subsequent splitting similar to that of the graphite tested by exposure to boiling sodium. It should be noted that these samples were tested by a different experimental procedure. Moreover, these materials were not treated with ethy 1 alcohol and water to remove the sodium and were not exposed to air, because it was found that the sodium-removal procedure and exposure to air caused deterioration in other materials. No crushing strength tests were performed on the graphites or on the vitreous carbon.

\section{F. Control Materials}

Rods of boron carbide $\left(\mathrm{B}_{4} \mathrm{C}\right)^{9}$ and tantalum were exposed to sodium at $850^{\circ} \mathrm{C}$ for five hours. Both survived exposure with no apparent interaction. The sodium coating the samples was still clean and shiny after the five-hour exposure as can be seen in Figs. 32 and 33 .

\section{G. Miscellaneous}

A quartz tube, a thoria $\left(\mathrm{ThO}_{2}\right)$ rod, and a beryllia (BeO) crucible were exposed to sodium at $850^{\circ} \mathrm{C}$ for five hours. The quartz tube $\left(100 \%\right.$ fused $\left.\mathrm{SiO}_{2}\right)$ suffered a total loss of structural integrity after exposure. The quartz appeared as a thick residue at the bottom of the capsule. The overlying sodium was fairly clean, indicating the absence of an extensive chemical reaction, but the walls of the capsule were not wetted with sodium, as may be seen in Fig. 34. Although quartz is used for sodium sampling at temperatures on the order of $370^{\circ} \mathrm{C}$ in EBR-II, ll quartz devitrifies in the presence of sodium above $800^{\circ} \mathrm{C} .12$

The samples of thoria and beryllia survived the test with no apparent interaction. (Figs. 35-36). When the capsules containing these samples were opened, both the samples and the interior walls of the capsules were coated with clean, shiny sodium. However, the sodium coating on the thoria sample covered only that portion of the sample that had been submerged in liquid sodium; the portion of the sample exposed to sodium vapor was not coated (see Fig. 36). 


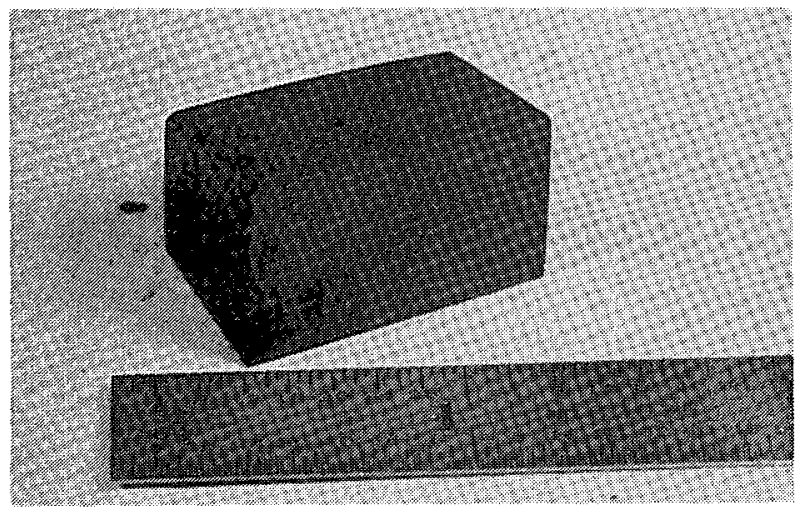

a. Before Sodium Exposure

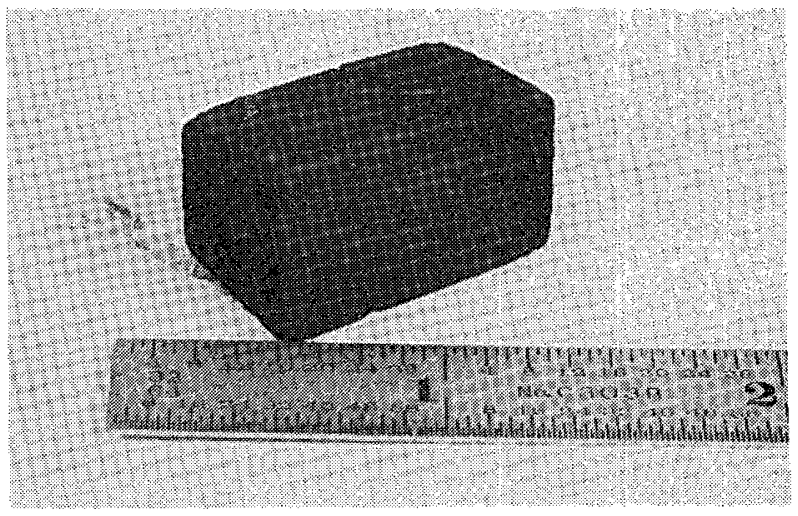

b. After Exposure to Boiling Sodium; After Sodium Removal

Fig. 27. High-density Graphite Brick before and after Exposure to Boiling Sodium

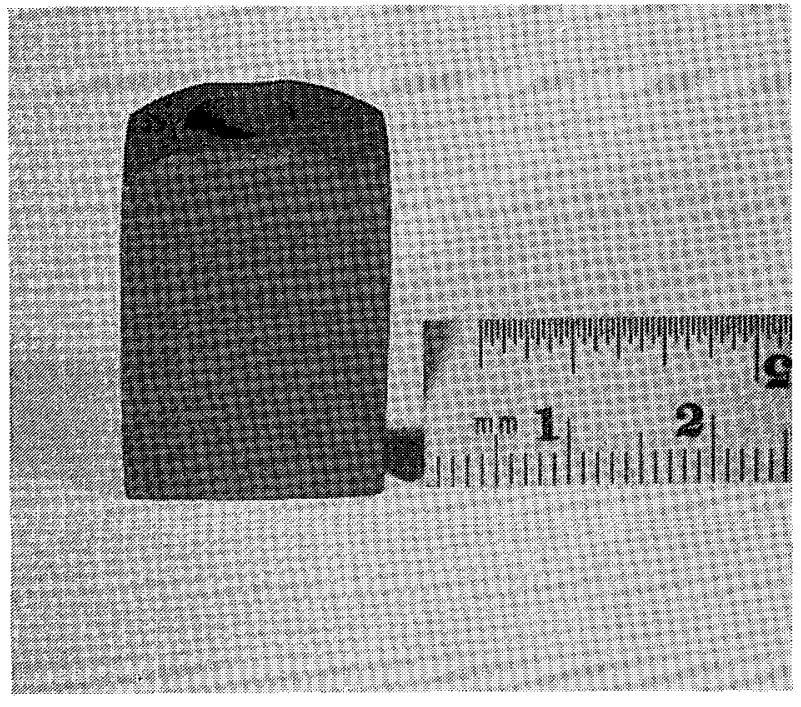

a. Before Sodium Exposure

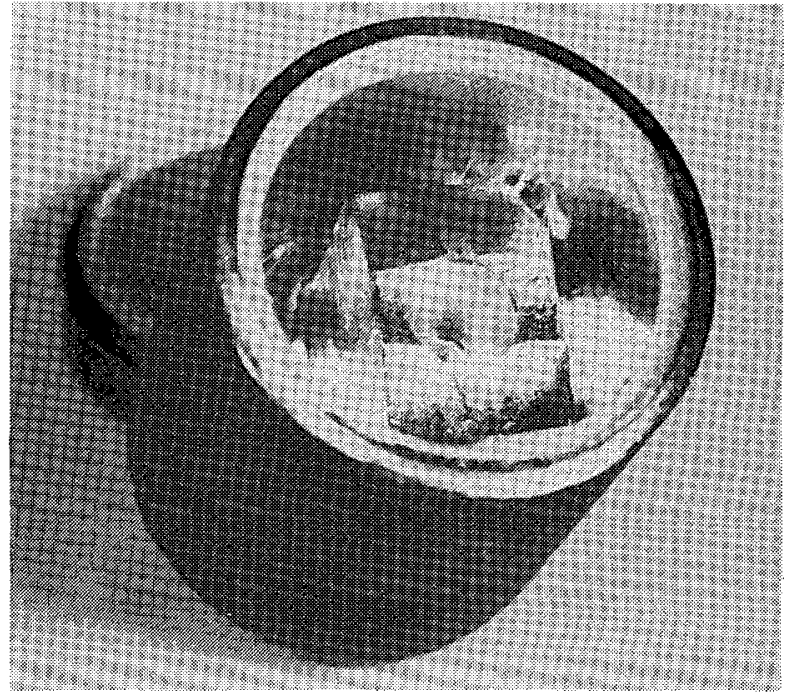

b. After Exposure to Static Sodium

Fig. 28. Sample of ATJ Graphite before and after Exposure to Static Sodium at $850^{\circ} \mathrm{C}$ 


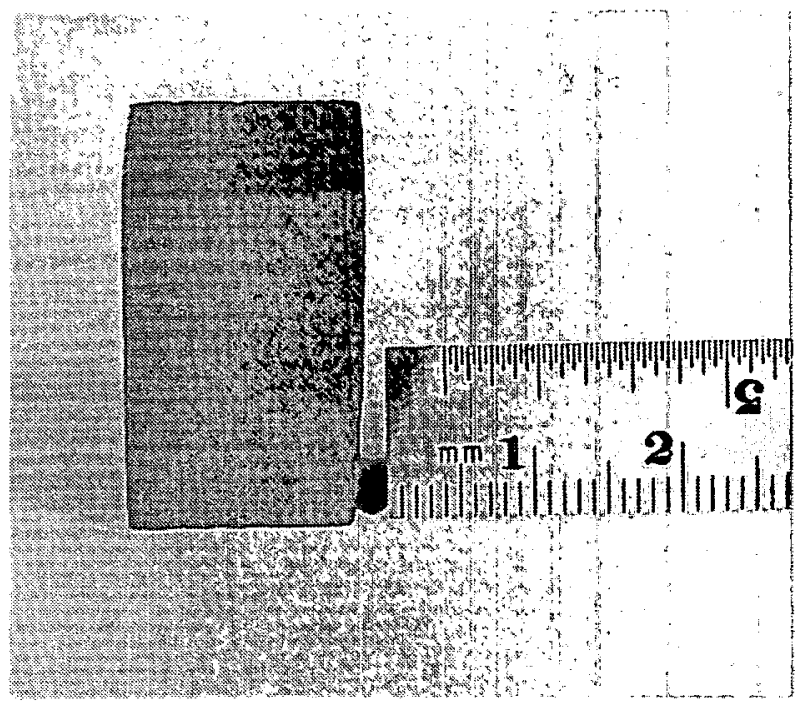

a. Before Sodium Exposure

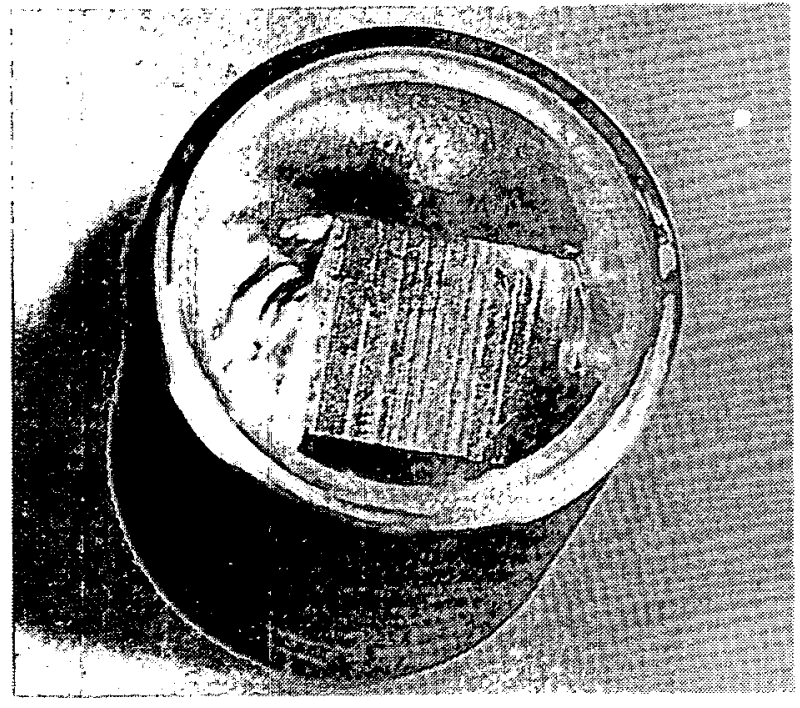

b. After Exposure to Static Sodium

Fig. 29. Reactor Grade Graphite, AGOT, before and after Exposure to Static Sodium at $850^{\circ} \mathrm{C}$

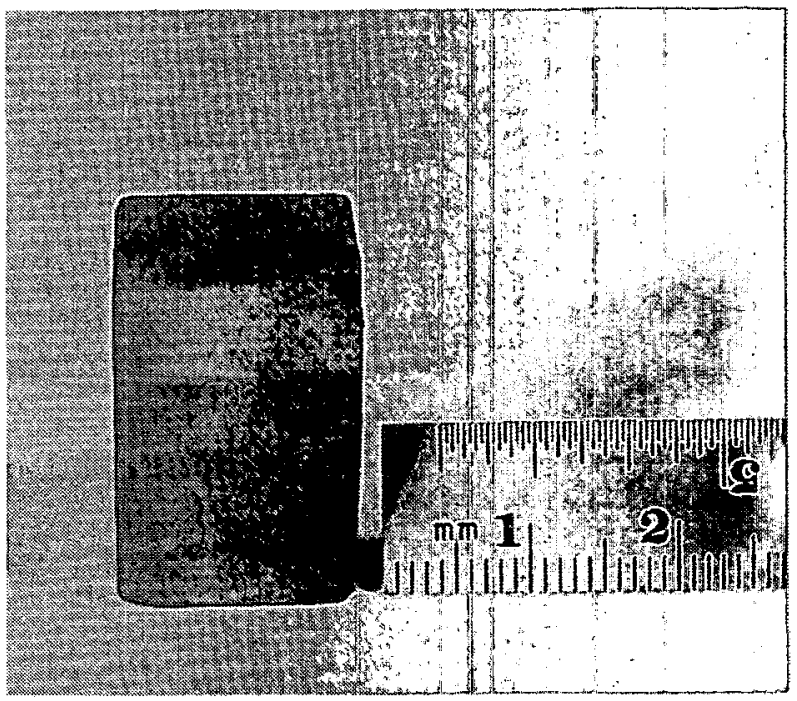

a. Before Sodium Exposure

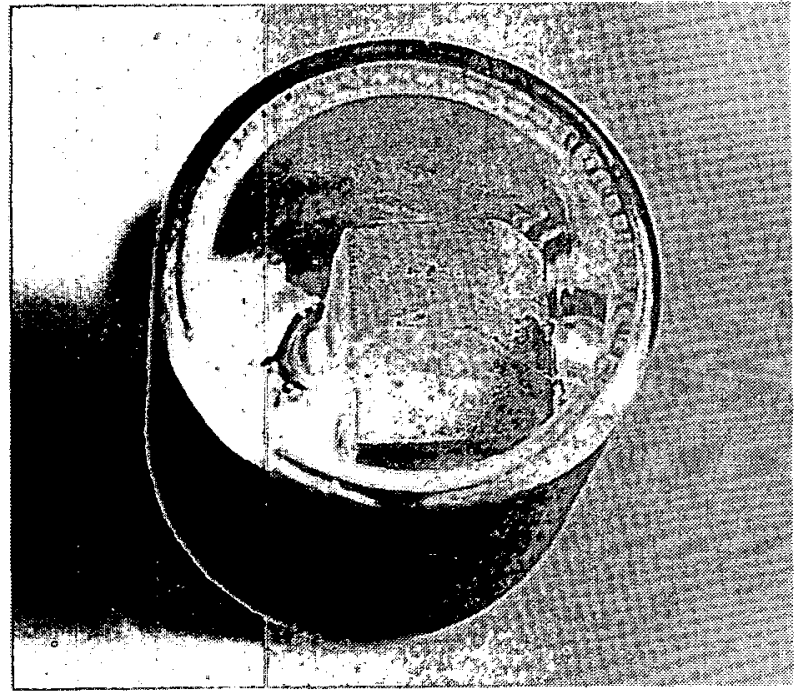

b. After Exposure to Static Sodium

Fig. 30. Sample of FC-14 Graphite before and after Exposure to Static Sodium at $850^{\circ} \mathrm{C}$ 


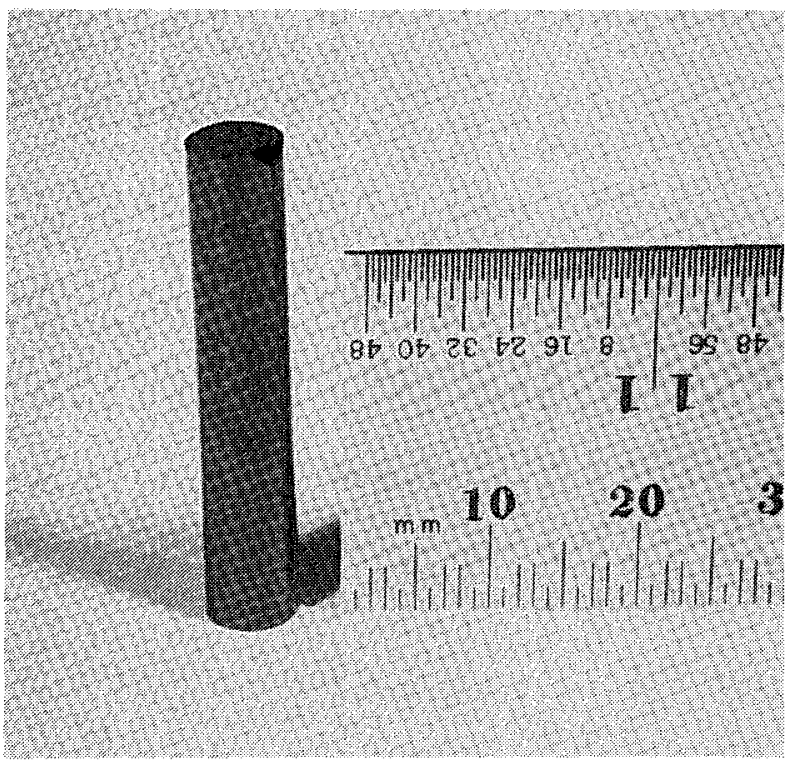

a. Before Sodium Exposure

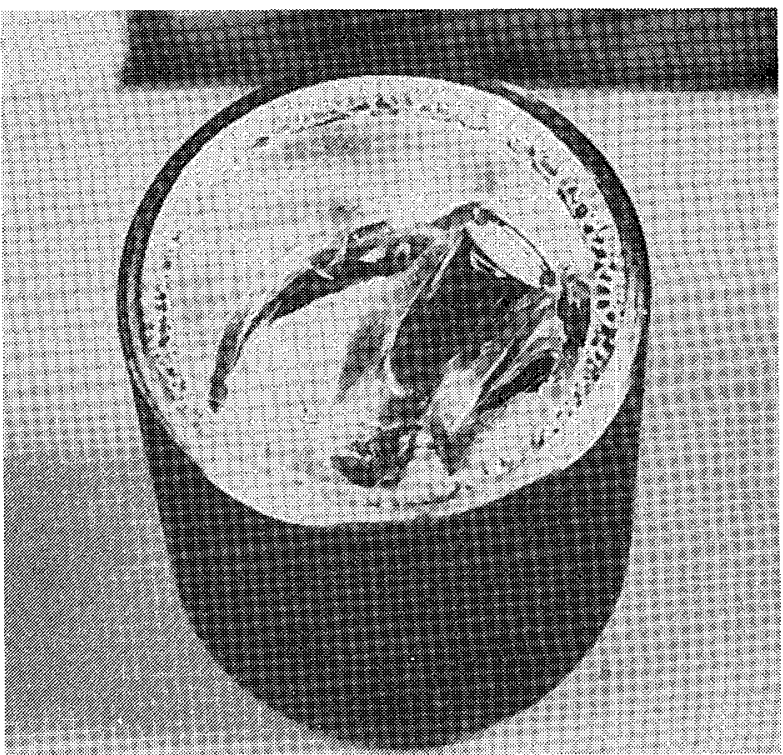

b. After Exposure to Static Sodium

Fig. 31. Vitreous Carbon Rod before and after Exposure to Static Sodium at $850^{\circ} \mathrm{C}$

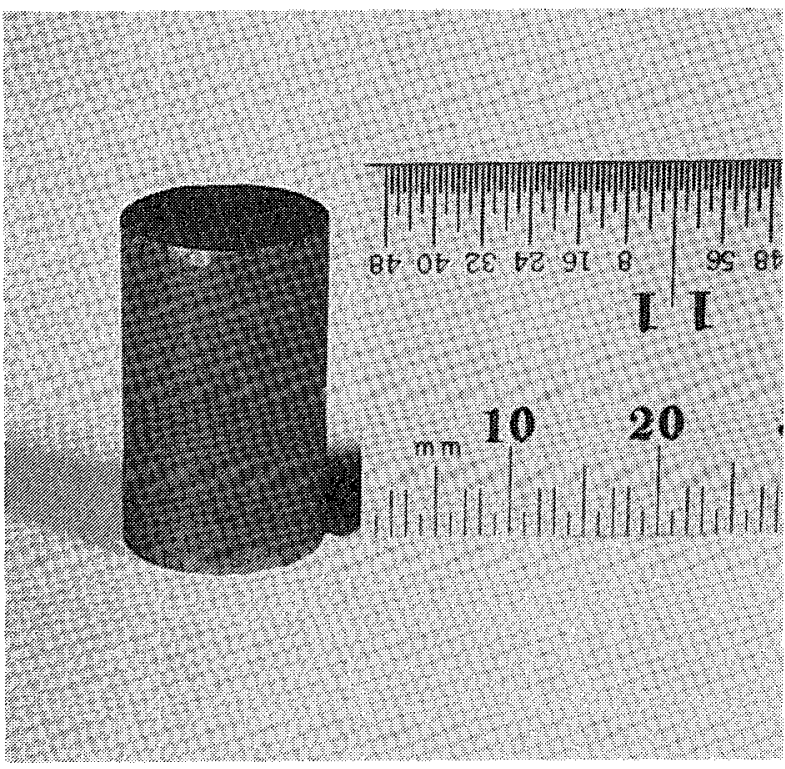

a. Before Sodium Exposure

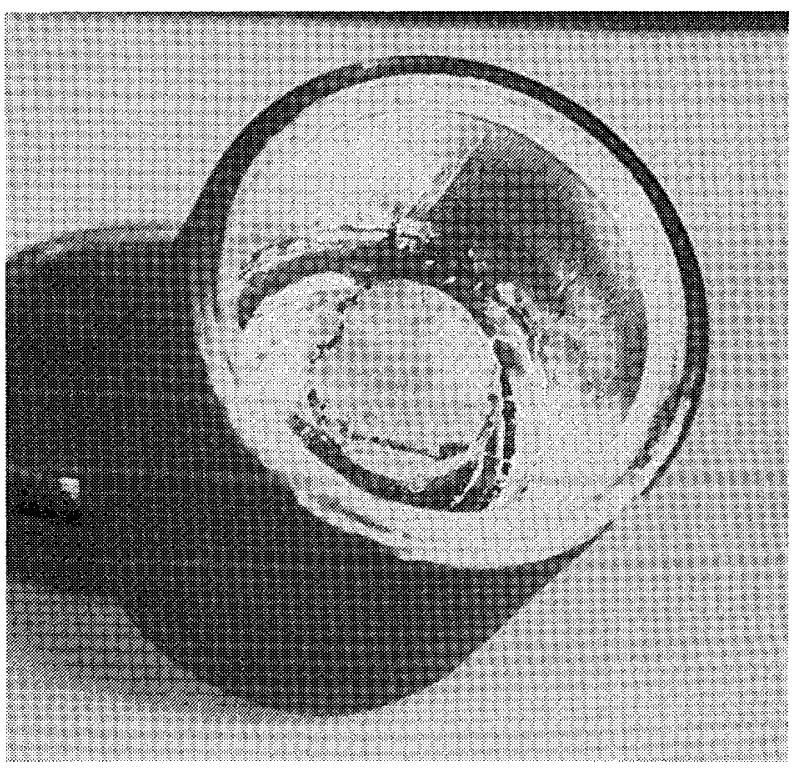

b. After Exposure to Static Sodium

Fig. 32. Boron Carbide $\left(\mathrm{B}_{4} \mathrm{C}\right)$ Rod before and after Exposure to Static Sodium at $850^{\circ} \mathrm{C}$ 


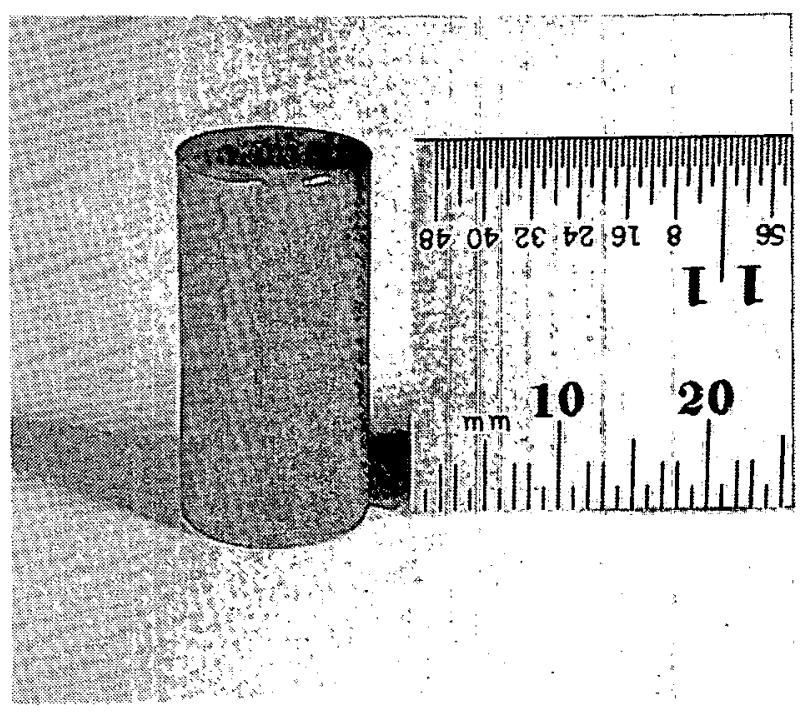

a. Before Sodium Exposure

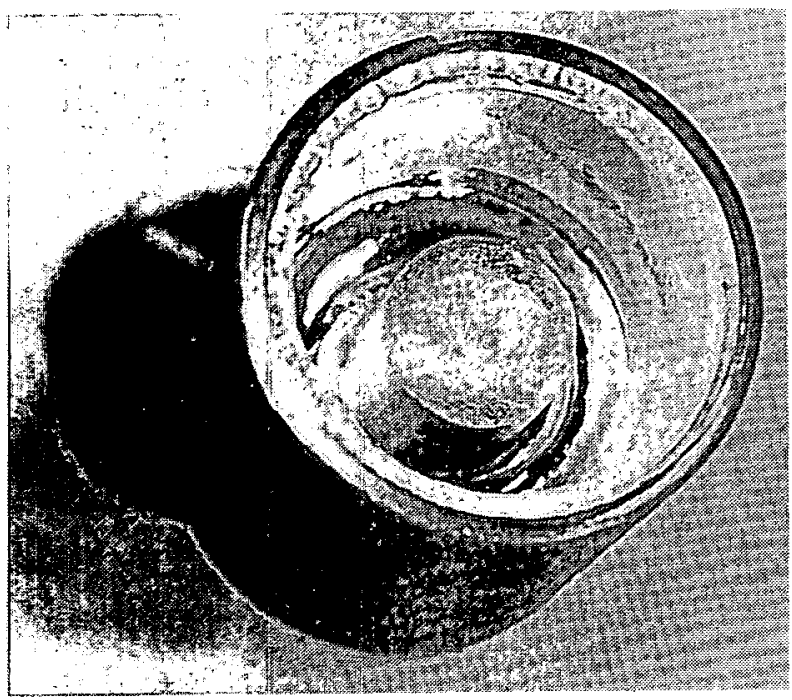

b. After Exposure to Static Sodium

Fig. 33. Tantalum Rod before and after Exposure to Static Sodium at $850^{\circ} \mathrm{C}$

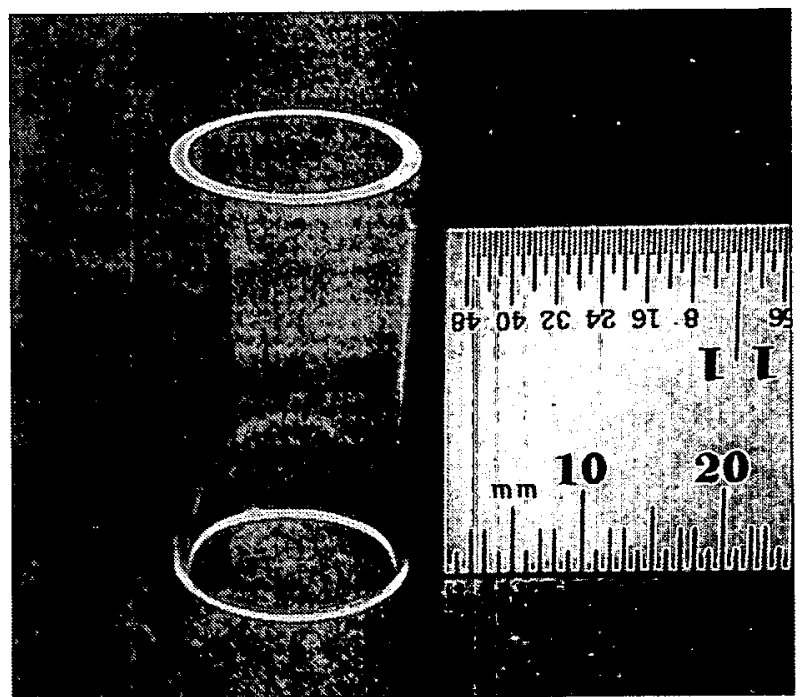

a. Before Sodium Exposure

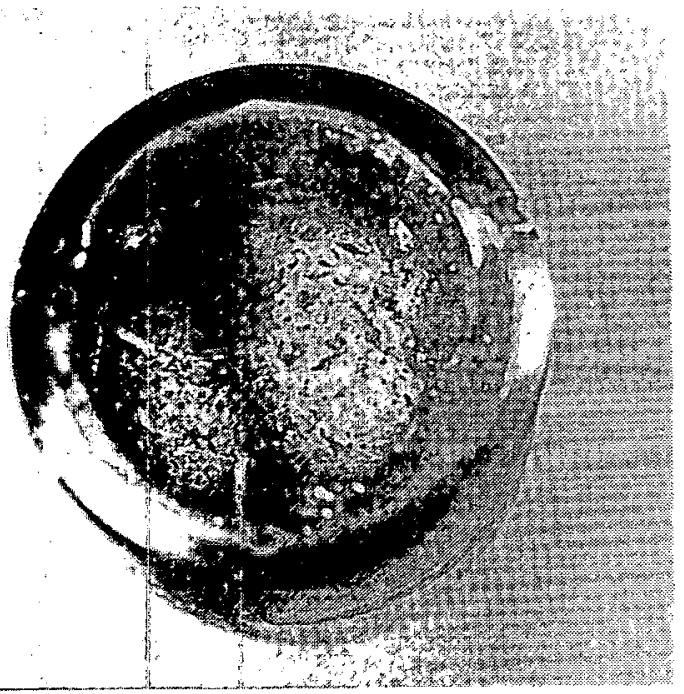

b. After Exposure to Static Sodium

Fig. 34. Quartz Tube before and after Exposure to Static Sodium at $850^{\circ} \mathrm{C}$ 


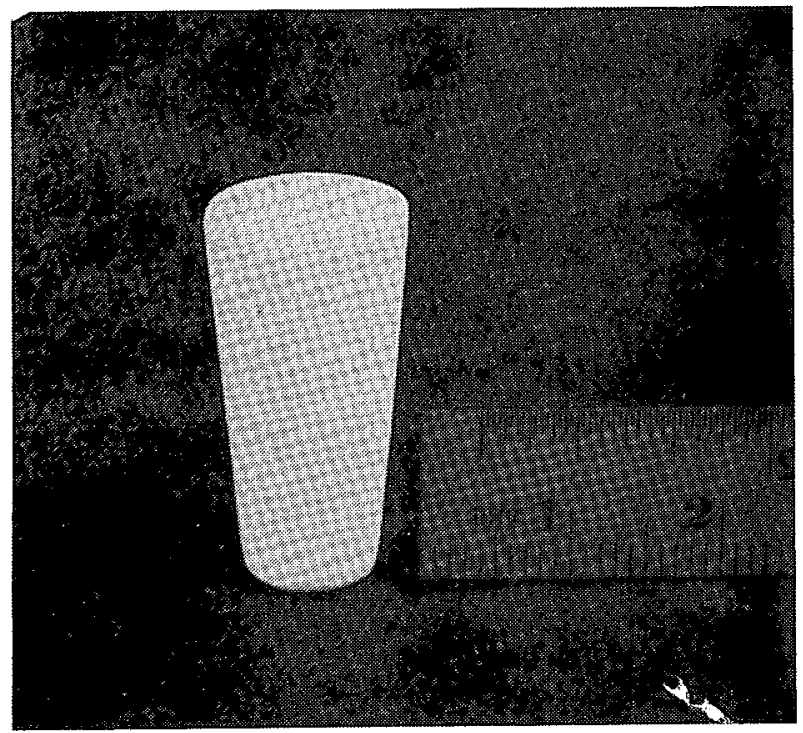

a. Before Sodium Exposure

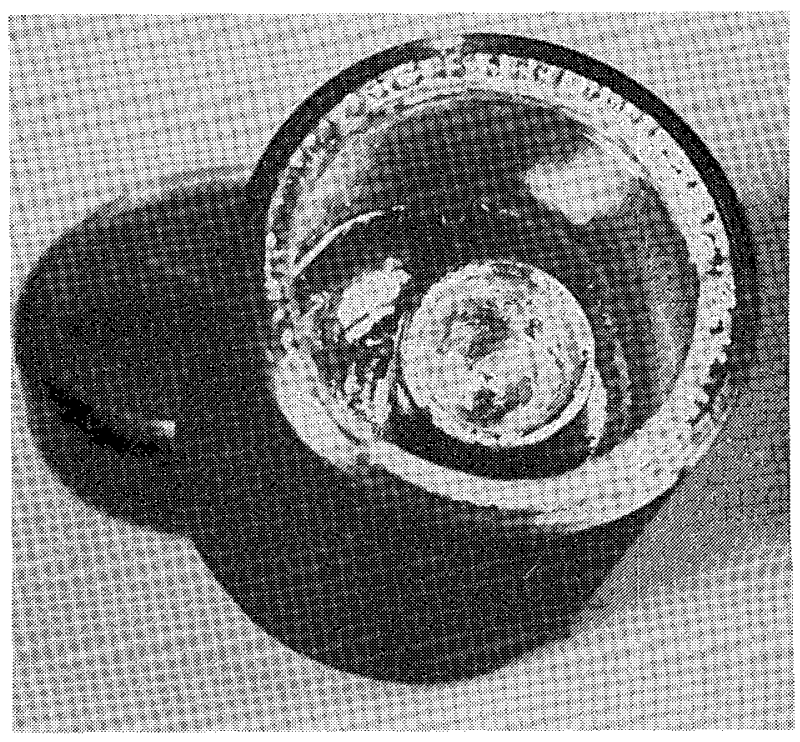

b. After Exposure to Static Sodium

Fig. 35. Beryllia Crucible before and after Exposure to Static Sodium at $850^{\circ} \mathrm{C}$

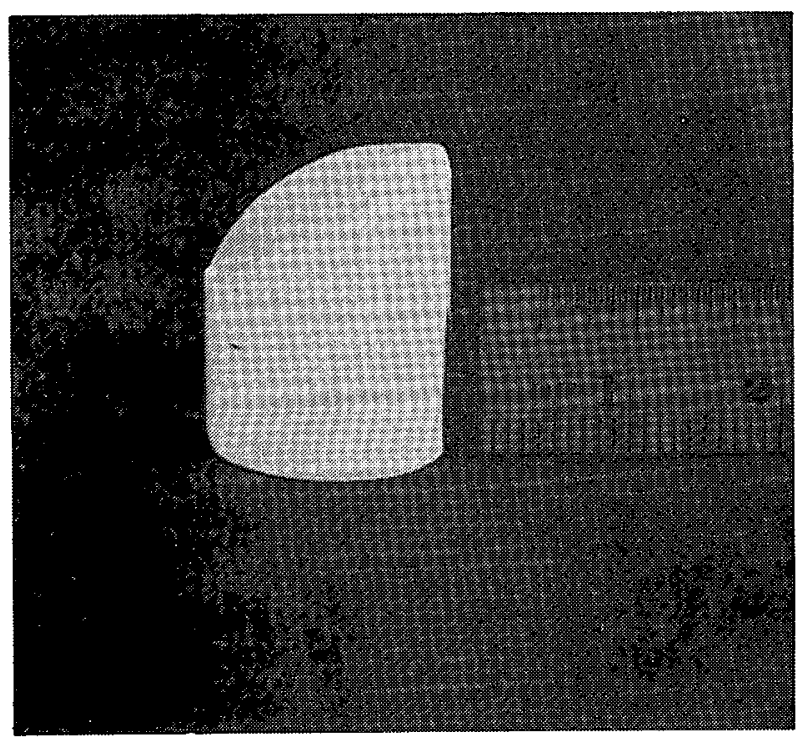

a. Before Sodium Exposure

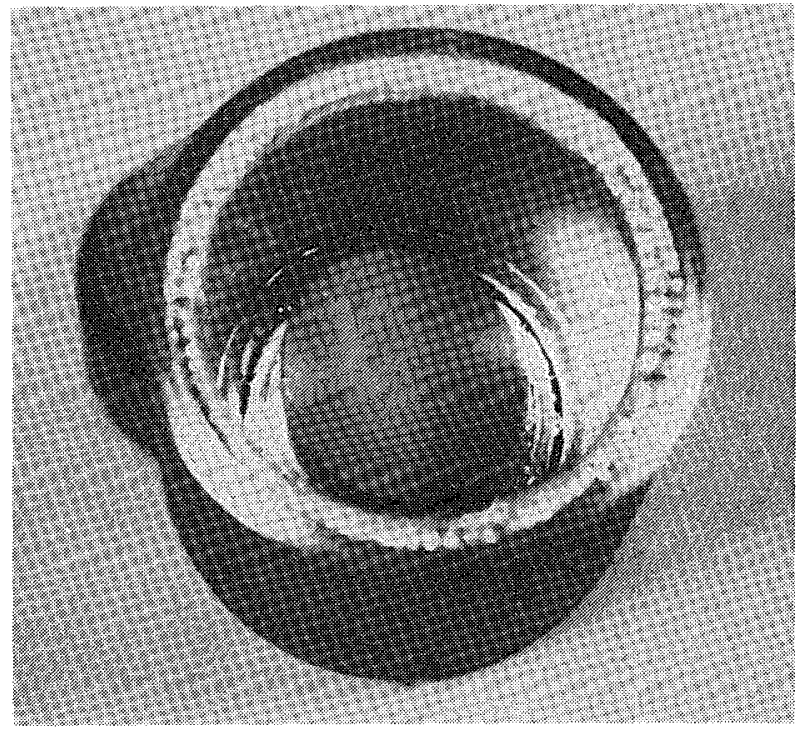

b. After Exposure to Static Sodium

Fig. 36. Thoria Rod before and after Exposure to Static Sodium at $850^{\circ} \mathrm{C}$ 


\section{CONCLUSION}

The results of these experiments indicate that several commercially available refractories are compatible with high-temperature and boiling sodium. These include materials that have high contents of magnesia and alumina, but low contents of silica and chromic oxide. Mixed ceramic oxides with a magnesia-chromic oxide base and low content of silica survived intact, but with some reduction in strength. High-fired crucibles of zirconia withstood exposure to high-temperature static sodium and boiling sodium, but refractory bricks of zirconia did not survive exposure to boiling sodium. Thoria, beryllia, tantalum, boron carbide, and all the grades of graphite tested survived a five-hour exposure to static sodium at $850^{\circ} \mathrm{C}$. Quartz was found not be be compatible with sodium at $850^{\circ} \mathrm{C}$.

The capability of samples containing silica to withstand exposure to sodium decreased as the amount of silica increased. Samples containing large amounts of silica failed completely in the sodium exposure experiments, whereas those with low silica contents survived intact, but with some loss of strength. Thermodynamically, silica is more stable than sodium monoxide, whereas sodium silicate is very stable. Silica reacts with sodium vapor according to the reaction

$$
4 \mathrm{Na}+5 \mathrm{SiO}_{2} \rightarrow 2 \mathrm{Na}_{2} \mathrm{Si}_{2} \mathrm{O}_{5}+\mathrm{Si}\left(\Delta \mathrm{F}_{298 \mathrm{~K}}=-107.4 \mathrm{kcal}\right) .12
$$

Therefore, sodium could attack the silica in the refractories, causing failure of the samples.

The failure of samples of zirconia containing large amounts of silica can be attributed to the presence of silica. However, zirconia bricks containing less than $1 \%$ silica also failed. Since the zirconia crucible (Norton Mix $\mathrm{Z}-302$ ), which had the same chemical composition as the bricks ( $2 \mathrm{H} 192 \mathrm{~A}$ and $\mathrm{ZH}$ 392C), did not fail, the failure of the bricks may be due to some factor introduced by the difference in fabricating procedures for bricks and highfired crucibles. Although our tests indicate that high-fired zirconia materials are compatible with high-temperature and boiling sodium and bricks of high zirconia content are not, these results are not conclusive, because, at WARD, samples of the same high-zirconia bricks as those tested at ANL survived exposure to sodium, with only some discoloration and surface powdering.

For all commercial refractories tested, except for the high-zirconia bricks, the results of our experiments are in excellent agreement with those obtained at WARD. 


\section{ACKNOWLEDGEMENTS}

The authors wish to thank S. Ramchandran and N. F. Heylmun of Westinghouse Advanced Reactors Division for providing us with refractory samples of the same composition as those tested at WARD.

Thanks are also due to J. Bingle for figure preparation, proofreading, and his helpful comments on the report, to $\mathrm{J}$. Royal for his editorial assistance, and to $\mathrm{K}$. Wall and $\mathrm{E}$. Residori for their excellent typing of this report. 


\section{REFERENCES}

1. J. C. Hesson, Retaining Fast Reactor Fuel Debris in the Secondary Containment, Trans. ANS, 14(1), 294 (1971).

2. R. Kumar, Ex-vessel Core Retention Concepts, Argonne National Laboratory, unpublished (October 1974).

3. G. James and D. D. Stepnewski, Nucl. Tech. 17, 85 (1973).

4. R. Kumar, Ex-vesse1 Postaccident Heat Removal, Chemical Engineering Division Reactor Safety and Physical Property Studies Annual Report, ANL-8120, 100 (July 1974).

5. W. D. Tuohig, J. T. A. Roberts, and R. H. Singh, Material Studies in Support of Liquid Metal MHD Systems, Proc. of the $14 \mathrm{th}$ Symp. on Engineering Aspects of Magneto Hydrodynamics, U. of Tennessee Space Institute (April 8-10, 1974).

6. M. G. Chasanov and D. R. Fredrickson, Interaction of Sodium and Basalt, Chemical Engineering Division Reactor Safety and Physical Property Studies Annual Report, ANL-8120, 97 (July 1974).

7. S. A. Meacham, Sodium Capability of Refractory Materials Considered for CRBRP Parallel Design Ex-vessel Core Retainers, Westinghouse Advanced Reactors Division report, WARD-D-0077 (April 1975).

8. J. D. Gabor, E. S. Sowa, L. Baker, Jr., and J. C. Cassulo, Studies and Experiments on Heat Removal from Fuel Debris in Sodium, Proc. Fast Reactor Safety Meeting, Beverly Hills, Calif., CONF-740401-P2 (April 2-4, 1974) p. 823 .

9. For further specifications on the $\mathrm{B}_{4} \mathrm{C}$ sample, refer to the paper Preirradiation Characterization of $\mathrm{B}_{4} \mathrm{C}$ Pellets used in Experiments on High-Worth Control Rods by D. E. Walker, ANL/EBR-051 (January 1972).

10. C. A. Hampel and G. G. Hawley, The Encyclopedia of Chemistry, 3rd ed., N. Y. Van Nostrand (1973).

11. H. W. Olsen, Sampling and Analysis of EBR-II Sodium, ANL-7844 (May 1971).

12. C. A. Elyard and H. Rawson, Advances in Glass Technology, Proc. 65h Int. Congr. on Glass, Washington, D. C., Plenum Press, New York (1972) pp. 270-286. 